\title{
Vascular anticoagulant : a new physiological anticoagulant mechanism
}

Citation for published version (APA):

Reutelingsperger, C. P. M. (1987). Vascular anticoagulant : a new physiological anticoagulant mechanism. [Doctoral Thesis, Maastricht University]. Rijksuniversiteit Limburg. https://doi.org/10.26481/dis.19870619cr

Document status and date:

Published: 01/01/1987

DOI:

$10.26481 /$ dis. $19870619 \mathrm{cr}$

Document Version:

Publisher's PDF, also known as Version of record

\section{Please check the document version of this publication:}

- A submitted manuscript is the version of the article upon submission and before peer-review. There can be important differences between the submitted version and the official published version of record.

People interested in the research are advised to contact the author for the final version of the publication, or visit the DOI to the publisher's website.

- The final author version and the galley proof are versions of the publication after peer review.

- The final published version features the final layout of the paper including the volume, issue and page numbers.

Link to publication

\footnotetext{
General rights rights.

- You may freely distribute the URL identifying the publication in the public portal. please follow below link for the End User Agreement:

www.umlib.nl/taverne-license

Take down policy

If you believe that this document breaches copyright please contact us at:

repository@maastrichtuniversity.nl

providing details and we will investigate your claim.
}

Copyright and moral rights for the publications made accessible in the public portal are retained by the authors and/or other copyright owners and it is a condition of accessing publications that users recognise and abide by the legal requirements associated with these

- Users may download and print one copy of any publication from the public portal for the purpose of private study or research.

- You may not further distribute the material or use it for any profit-making activity or commercial gain

If the publication is distributed under the terms of Article $25 \mathrm{fa}$ of the Dutch Copyright Act, indicated by the "Taverne" license above, 
VASCULAR ANTICOAGULANT

- A NEW PHYSIOLOGICAL ANTICOAGULANT MECHANISM - 
Drukkerij Groenevelt b.v. - Landgraaf Omslag: Willem Berings 


\title{
Vascular Anticoagulant \\ - A New Physiological \\ Anticoagulant Mechanism -
}

\author{
Proefschrift
}

ter verkrijging van de graad van doctor in de geneeskunde aan de Rijksuniversiteit Limburg te Maastricht, op gezag van de Rector Magnificus, prof. dr. F.I.M. Bonke, volgens het besluit van het College van Dekanen, in het openbaar te verdedigen op vrijdag 19 juni 1987 des namiddags om vier uur

door

Christiaan Peter Maria Reutelingsperger

geboren te Schaesberg 
Promotor : Prof. dr. H.C. Hemker

Co-promotor: Dr. G. Hornstra

Referenten : Prof. dr. R. Reneman, Maastricht

: Prof. dr. B. Bouma, Utrecht

: Prof. dr. P. Swetly, Wenen, Oostenrijk

'De Nederlandse hartstichting' contributed to the printing costs of this thesis. 
- 'existance conditions consciousness' is true for as long

as it takes consciousness to acquire the art of estrangement; thereafter, consciousness is on its own and can both condition and ignore existance.Joseph Brodsky

Ter herinnering aan mijn moeder aan mijn vader aan Patricia 
Dit werk is het resultaat van een wisselwerking tussen $U$ en mij, Ik ben $U$ daarvoor dankbaar. 
CONTENTS

Chapter 1

Chapter 2: Isolation and partial purification of a novel anticoagulant from arteries of human umbitical cora.

Chapter 3: Purification and characterization of

a novel protein from bovine aorta

that inhibits coagulation.

Chapter 4: Rapid purification and further characterization of the vasular anticoagulant (WAC).

Chapter 5: Immunological and chemical detection of vascular anticoagulant (VAC) in cultured human vascular endothelial cells.

Chapter 6: A new homeostatic mechanism to control thrombin formation at the vessel wall 1 in $\mathrm{n}$ ing.

Chapter 7: Conclusions and summary.

conclusies en samenwating. 
B

BS

BTP

$C B B$

Da.

DAB

$D A F$

D) $\mathrm{PC}$

DOPS

EDTA

E.C.

FELC

$\mathrm{GL}_{\mu} \mathrm{A}$

HAP

HUVE

$\mathrm{K}-\mathrm{H}$

\section{$M P T-t e s t$}

$\mathrm{Mr}$

PFP

$\mathrm{PPP}$

PRP

$\operatorname{sis}$

SDS-PAGE

52236

52337

THS

TBSA

TDSE

WAC

\section{Anthbodes}

Buffered Saline; $110 \mathrm{~mm}$ NaCl, 20 mM $\mathrm{NaHCO}_{3} 4 \mathrm{mM} \mathrm{KCL,}$ 14 mM glucose, 4 mg/ml bovine serum albumine, pH 7.4 Bovine Brain Thromboplastin

Coomassie Brilliant Blue

Dalton

3,3-Diamino-benzidine-tetrachloride

Ditethylaminoethyl

1, 2-Dioleoy 1-sn-glycero-3-phosphocholine

1.2-D1oleoyl-sn-glycero-3-phosphoserine

Ethylenedinitro Tetwacetic ACid Disodium Salt

Final Comcentration

East protein wiquid chromatography

- Carboxy Glutamic Acid

Horse Radish Peroxidase

Human Umbilical Cord Venous Endothelial Cell

Krebs-Henseleit BufEer; 120 mM NaCl, 4.7 mM KCL, 1.2

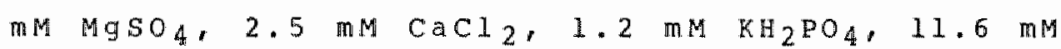
glucose, $25 \mathrm{mM} \mathrm{NaHCO}, \mathrm{pH} 7.4$

Madified Prothrombin Time Test

Relative Nolecular Mass

Platelet Free Plasma.

platelet poor Plasma

platelet Rich Plasma

sodium bodecyl sulfate

polyacryamide Gel Electrophoresis with sps

D-phenyla lanyl- - pipecolylarginine-p-nitúanilide ditydrochloride

N-Benzoy -L-isoleucyl-L-arginine-p-nitroanilide hydro$\operatorname{chlor} \mathbb{1} d e$

Tris Buffer; $100 \mathrm{mM} \mathrm{NaCl,} 50$ mM Tris/HCl, pH 7.9

[LBS containing $0.5 \mathrm{mg} / \mathrm{ml}$ human serum alburine

IBS containing $2 \mathrm{mM}$ EDTA

vascular Anticoagulant 
CHAPER 1

INTRODUCEION 
INTRODUCTION

Blood coagulation comprises a complex series of reactions, which is initiated following blood vessel injury. A large number of proteins have been discovered to participate in the coagulation process. To our current knowledge fits best a conceptual model of a staged cascade, in which certain proteins form a distinct reaction stage (1). The separated reaction stage can heuristically be presented as shown in fig. 1. The functional entity is the enzyme subatrate complex. The enzyme, an activated coagulation factor, cleaves a specific bond of the substrate, a coagulation zymogen, which, thereby, becomes enzymatically active (2). The rate of this enzymatic reaction is extremely low but can be greatly accelerated when enzyme and substrate interact with catalyzing compounds such as monenzymatic protein cofactors and surfaces. Three of the vitamin K-dependent coagulation factors (II, IX, and $x)$, which posses specific $v$-carboxyglutamic acid residues (GLA, 3), are involved in two important stages in the cascade, $1 . e$. the intrinsic $X$-activation ( $I x_{a}$ and $\left.X\right)$ and prothrombinase ( $x_{a}$ and II). Both reactions require calcium ions and negatively charged phospholipids (4). The acidic phospholipids exert a high impact on the kinetic parameters of the enzymatic reactions $(5,6)$. The precise mode of action of these phospholipids is still a subject of debate $(7-9)$. It is generally accepted, however, that for this stimulatory effect of the phospholipids, the k-related proteins have to bind to the phospholipid surface. This binding has been extensively studied, using several techniques (10-16) and appaers to be governed by the GLA-residues and by calcium ions (17). The nonenzymatic protein cofactors va and VIIIa, which lack GLA-residues, enthance the enzymatic conversion of II and $x$, respectively $(5,6)$. These protein cofactors form a $1: 1$ stoichiometric complex with the activated coagulation factors $x_{a}$ and $I_{a}$, thereby facilitating the binding of these enzymes to the negatively charged phospholipids $(12,18,19)$.

The coagulation cascade is an amplifying system: in the presence of the required accesory components, a molecule of an activated 


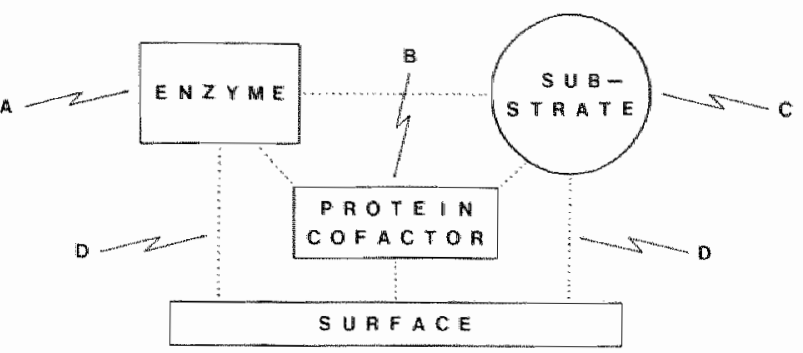

Pig. 1. Schematic representation of the structure of a reaction stage in the blood coagulation cascade.

The dotted lines represent the interactions between the different components of the complex. When the enzyme and the substrate are vitamin $\mathbb{K}$-related proteins, the surface is formed by negatively charged phospholipids, and the protein cofactors are $v_{a}$ (prothrombinase) and VII (intrinsic $x$-activation).

The arrows indicate the sites of action of 4 different anticoagulant mechanisms $(A, B, C$, and $D)$, which are discussed in the text.

coagulation factor in the top of the cascade enables the formation of a large number of molecules of thrombin, the ultimate enzymatically active product of the cascade. In vivo, a minor activation of the coagulation cascade would, thus, result in a clotting of the entire blood. Anticoagulant mechanisms, however, strengthen the hair of this sword of Damocles.

on basis of their site of action, the anticoagulant mechanisms can be divided into 4 major groups (fig. 1 ).

A). This large group of anticoagulants comprises the plasma protease inhibitars. They bind apparentiy irreversibly in a time dependent process to an activated coagulation factor, which, thereby, becomes inactive (20).

Antithrombin III, the anticoagulant activity of which is enhanced by heparin (21), is a well studied member of this group. The vital role of antithrombin II as a physiological anticoagulant is indicated by the fact that patients with congenital antithrombin II deficiency, frequently develop thrombotic diseases $(22-24)$. 
B). With the isolation and characterization of the vitamin $\mathrm{K}$ related protein $\mathrm{C}$, a new anticoagulant mechanism was discovered (25). This pathway appeared to comprise a complex series of reactions, involving seweral plasma and tissue proteins. protein c, which circulates in the plasma as a zymogen, is efficiently activated by thrombin in the presence of a cell surtace-bound protein, thrombomodulin (26). The activated protein c rapidy cleaves the protein cofactors $v_{a}(27)$ and VIIIa (28) in the presence of protein $S$ (29) and an, as yet undefined, compound on the endothelial cell surface (30). The cleaved protein cofactors are inactive in the coagulation process. The physiological significance of the protein $C$ anticoagulant pathway is illustrated by the repeated thrombotic episodes occurring in several families with congenital reduction in the antigenic levels of protein $C$ $(31,32)$.

c). Witamin $k$ is a prerequisite for the posttranslational formation of GLA-residues in the K-related coagulation factors (33-35). A defictency of this vitamin induces the synthesis of anomalies of these coagulation factors $(36,37)$. These anomalies lack GLA-residues and are, therefore, poor substrates in the coagulation process (38). In contrast to the first two mentioned anticoagulant mechanisms, the vitamin $k$-deficiency is not a physiological mechanism, but is introduced in man by the administration of vitamin K-antagonists and serves the purpose of decreasing thrombotic tendency in patients (39).

D). This group of anticoagulants comprises compounds that interfere with the interaction of the clotting factor with a surface. on basis of the different types of interaction, this group can be divided into 4 subsets.

I. To this group belong some basic phospholipases that bind to a phospholipld bilayer in a calcium-independent way. They penetrate this bilayer and hydrolyze various of its components. The anticoagulant action of the phospholipases is explained by the occupation of the phospholipid surface and by changing the surface properties as a result of hydrolysis $(40,41)$. The phospholipases investigated so far originate 
from viper venoms. At the moment it is not clear whether this mechanism is of physiological importance in man.

I. This second subset comprises the lupus anticagulant, which indicates a heterogenous group of acquired immunoglobulins, mostly of the IgG and IgM type, which may bind to procoagulant phospholipids, and which act as inhibitors of in vitro clotting tests (42). The binding of lupus anticoagulants to negatively charged phospholipids has recently been demonstrated $(43,44)$. Moreover, this interaction inhibits the binding of II and $x$ to these phospholipids (43). Lupus anticoagulant is rarely associated with hemorrhage (45) but has frequently been observed in an apparently paradoxical association with thrombosis (46-48). One of the explanations for this phenomenon is that the interaction between dupus anticoagulant with platelets and endothelial cells may result in a thrombosis predisposing situation (49). Another explanation says that the lupus anticaagulant inhibits other anticoagulant mechanisms, like the endothelial prostacyclin production (50) and the endothelial thrombomodulin activity (44).

III. GLA - containing fragments of II and $x$ constitute this third subset of anticoagulants. These fragments have been shown to inhibit certain procoagulant reactions. Fragment I inhibits the tissue factor pathway (51) and in particular the $x_{a}$-catalyzed prothrombin activaton (52). The inhibitory effect is due to an interaction of fragment 1 with the phospholipid surface, that results in a competition with the I $I$ binding and $x_{a}$ binding to this surface (52). Calcium and the fragment 1 GLA-residues are involved in this anticoagulant effect.

A GLA-rich peptide, derived from the light chain of $x$, is also an inhibitor of the phospholipid dependent procoagulant reactions (53). The anticoagulant effect of this peptide is totally dependent on the presence of the GLA-residues.

IV. This final anticoagulant mechanism is presented and discussed in extenso in this thesis. This new anticoagulant mecha- 
nism is ifleroduced by the discovery of the anticoagulant protein $\mathrm{VAC}$ (vascular anticoagulant) in human umbilical cora arteries (chapter 2). WAC does not contain GLA-residues, but nevertheless shows a calcium dependent high affinity binding to negatively charged phospholipids. As a result of this bliding $V A C$ interferes with the coagulation factor - phospholipid interaction. Consequently, VAC inhibits the phospholipid dependent procoagulant reactions chapters 3 and 4). WAC is demonstrated to be present in endothelial cells as an anticoagulant active moiety (chapter 5), which can inhibit the procoagulant activity of vessel wall structures (chapter 6). Hence, VAC provides an anticoagulant mechanism, which can control thrombin formation at the vessel wall lining. Its mechanism of action suggests, moreover, that VAC may be developed into a chemically relevant antithrombotic agent without the risk of bleeding.

\section{LITERATURE}

1. Jackson, C.M., and Nemerson, Y. 1980. Ann. Rev. Biochem. $49: 765-811$.

2. Tans, G., and Rosing, J. 1986. In Blood coagulation. New Comprehensive Biochemistry. (Hemker, H.C., and Zwaal, R.F.A., eds.). Vol 13, pp 59-85. Elsevier, Amsterdam.

3. Olsson, R.E. 1984. Ann. Rev. Nutr. 4:281-337.

4. Nelsestuen, G.L. 1984. In Metal ions in biological systems. (sigel, H., ed.). Vol 17: pp 353-380. Marcel Decker Inc. New York.

5. Rosing, J., Tans, G., Govers-Riemslag, J.W.P., Zwaal, R.F.A., and Hemker, H.C. 1980. J. Biol. Chem. 255:274-283.

6. van Dieijen, G., Tans, G., Rosing, J., and Hemker, H.C. 1981 J. Biol. Chem, 255:3433-3442.

7. Pusey, M.I., and Nelsestuen, G.L. 1983. Biochem. Biophys. Res. Commun. 114:526-532.

8. van Rijn, J.L.M.L.", Govers-Riemslag, J.W.P., Zwal, R.F.A., and Rosing, J. 1984. Biochemistry 23:4557-4564. 
9. Nesheil, M.E., Tracy, R.P., and Mann, K.G. 1984. J. BLol. Che r. $259: 1447-1453$.

10. Welsestuen, G.L., Kisiel, W. "and Discipio, R.G. I978. Biochemistry 17:2134-2138.

11. van Dieijen, G., Tans, G., van Rijn, J.L.M.L., wwal, R.F.A., and Rosing, J. 1981. Biochemistry 20:7096-7101.

12. van Dieijen, G., van Rijn, J.L.M.L., Govers-Riemslag, J.W.P., Hemker, H.C., and Rasing, J. 1995. Thromb. Res, 53:396-400.

13. Mertens, K., Cupers, R., van Wijngaarden, A., and Bertina, R.M. 1984. Biochem. J. 223:599-605.

14. Bloom, J.W., Nesheim, M.E., and Mann, K.G. 1979. Biochemistry $18: 4419-4425$.

15. van de Waart, P., Bruls, H., Hemker, H.C., and Lindhout, T. 1983. Biochemistry 22:2427-2432,

16. Kop, J.M.M., Cuypers, P.A., Lindhout, T., Hemker, H.C., and Hermens, W.Th. 1984. J. Biol. Chem. 259:13993-13998.

17. Nelsestuen, G.L. 1976. J. Biol. Chem. 251:5648-5656.

18. Nesheim, M.E., Taswel1, and Mann, K.G. 1979. J. Biol. Chem. $254: 1095-10962$.

19. Lindhout, T., Govers-Riemslag, J.W.P., van de Wart, P., themker, H.C., and Rosing, J. 1982. Biochemistry 21:5494-5502.

20. Travis, J., and Salvesen, G.S. 1983. Ann. Rev. Biochem. $52: 655-709$.

2I. Rosenberg, R.D., Damus, P.S. 1973. J. Biol, Chen. $248: 6490-6505$.

22. Egeberg, 0. 1965. Thromb. Diath. Haemorr, 13:516-530.

23. Marciniak, E., Farley, C.H., and Destmone, P.A. 1974. Blood $43: 219-231$.

24. Grumberg, J., Smallridge, R., and Rosenber, R.D. 1975. Ann. Surg. 181:791.

25. Stenflo, J. 1976. J. Biol, Chem. 251:355-363.

26. Esmon, N.L., Owen, W.G., and Esmon, C.T. 1982. J. B1ol. Chem. $257: 859-864$.

27. Walker, F.J., Sexton, P.W., and Esmon, C.T. 1979. Biochim. Biophys. Acta $571: 333-342$.

28. vehar. G.A., and Davie, E.W. 1980. Biochemistry 19:401-409. 
29. Walker, F.J. 1981, J. B101. Chem. 256:11128-11131.

30. Stern, D.M., Nawroth, P.P., Harris, K., and Esmon, C.T. 1986. J. Biol. Chem. 261:713-718.

31. Griffin, J.H., Evatt, B., Zimmerman, T.S., kleiss, A.J., and Widenan, C. 1981. J Clin. Invest. 68:1370-1373.

32. Broekmans, A.W., Veltkamp, J.J., and Bertina, R.M. 1983. $\mathbb{N}$. Engl. J. Med. 309:340-344.

33. Magnusson, S., Sootrup-Jensen, L., Petersen, T.E., Morris, H.R. and De11, A. 1974. FEBS Lett. 44:189-193.

34. Ne1sestuen, G.L., zytokovitcz, T.H., and Howard, J.B., 1974. J. Bilol. Chem. 249:6347-6350.

35. Stenflo, J., Fernlund, P., Egan, W., and Roepstorff, P. 1974. Proc. Nat1. Acad. Sci. USA 71:2730-2733.

36. Hemker, H.C., Veltkamp, J.J., Hensen, A., and Loeliger, E.A. 1963 Nature 200:589-590.

37. Reekers, P.P.M., Lindhout, M.J., Kop-Klaassen, B.H.M., and Hemker, H.C. 2973. Biochim. Biophys. Acta 317:559-562.

38. Stenflo, J., and suttie, J.W. 1977. Ann. Rev. Biochem. $46: 157-172$.

39. Sixty plus reinfarction study research group. 1980. Lancet I I $: 989-984$.

40. Verhey, H.M., Boffa, M.C., Rothen, C., Bryckaert, M.C., Verger, R., and de Haas, G.H. 1980. Eur. J. Biochem. $112: 25-32$.

41. Ewans, H.J., Franson, R., Qureshi, G.D., and Moo-Penn, W.E. 1980. J. Biol. Chem. 255:3793-3797.

42. Feinstein, D.I., and Rapaport, S.I. 1972. Prog. Hemostasis Thromb. $1: 75-95$.

43. Thiagarajan, P., Shapico, S., DeMarco, L. 1980. J. Clin. Invest. $66: 397-405$.

44. Freyssinet, J.M., Wiesel, M.L., Gauchy, J., Bonel, B., and Cazenave, J.P. 1986. Thromb. Haemost. 55:309-313.

45. Schleider, M.A., Nachman, R.L., Jaffe, E.A., and Coleman, M. 1976. Bload 48:499-506.

46. Angelo-Cano, E., Saltan, Y., and Clauvel, J. 1979. Lab. Clin. Med. $94: 312-323$. 
47. Mueh, J.R., Herbst, K.D., and Rapaport, S.I. 1980. Ann. Intern. Med. 92:156-159.

48. Lechner, K. , Pabinger,-Fashing, I. 1985. Haemostasis $15: 254-262$.

49. Feistein, D.I., 1985. N. Engl. J. Med. 313:1348-1350.

50. Carreras, L.0., Defreyn, G., Machin, S.J., Vermylen, J., Deman, R., Spitz, B., and van Assche, A. 1981. Lancet $1: 244-246$.

51. Forman, S. Bach, R., and Nemerson, Y. 1984. Fed. Proc. 43:1946.

52. Govers-Rienslag, J.W.P., speyer, H., Zwal, R, F.A., and Rosing, J. 1985. Thromb, Res. 38:375-388.

53. Nawroth, P.P., Kisiel, W., and stern, D.M. 1986. Thromb. Res. $4: 4: 625-637$. 

CHAPTER 2

ISOLATION AND PARTIAL PURIEICATION OF A NOVEL ANTICOAGULANT FROM ARTERIES OF HUMAN UMBILICAL CORD

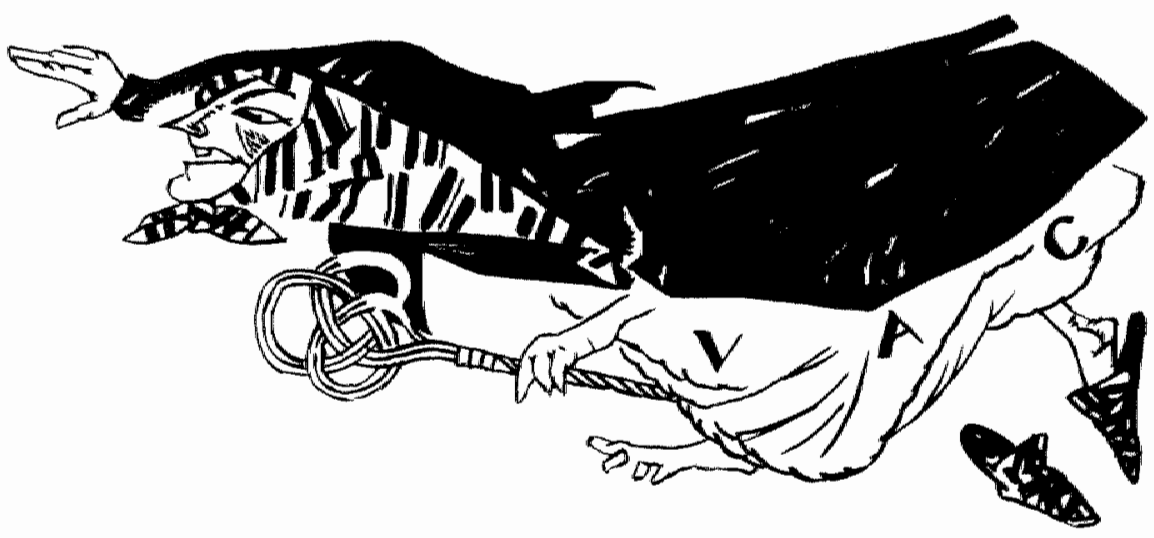



ISOLATION AND PARTIAL PURIFICATION OF A NOVEL ANTICOAGULANT EROM ARTERIES OF GUMAN UMBILICAL CORD

Reutelingsperger, C.P.M., Hornstra, G., and Hemker, H.C.

SUMMARY

An anticoagulant fraction was isolated from the homogenate of human umbilical cord arteries, using sephadex gel filtration and DEAE-Sephacel chromatography. Analysis with dodecyl sulfate/polyacrylamide gel electrophoresis and inactivation studies using proteolytic enzymes indicate that the anticoagulant activity is associated with a polypeptide with an apparent $M_{r}$ of 32000 . The anticoagulant inhibits thromboplastin as well as factor $x_{a}$ induced clotting but does not affect thrombin initiated fibrin formation. The anticoagulant inhibits the activation of prothrombin by the complete prothrombinase complex, by phospholipid bound factor $x_{a}$ but not by free factor $x_{a}$. The inhibition is instantaneous and independent of the incubation time over the whole range of concentrations tested. Therefore, the anticoagulant is unlikely to be a phospholipase or a protease. Its action does not resemble that of the plasma protease inhibitors, but it prabably interferes with the phospholipid-clotting factor interactions. 
INTRODUCTIOH

The coagulation cascade, wich has been studied extensively in the last decades, is now considered to be a multistage amplifying syotem of several linked proteolytic reactions in which an enzym converts a zymogen into its active form (for review see ref. 1). The rate of these reactions is considerably enhanced by the presence of phospholipids and protein cofactors lfactor Var Eactor VIII) $(2,3)$. In wivo, the procoagulant reactions are controlled by several inhibitory mechanism which prevent an explosive thrombotic event upon minor activation of the coagulation cascade.

Unti1 now the three major anticoagulant mechanisms have been recognized (for review see ref. 4). (a) the serine protease factor $x_{a}$ and thrombin are inactivated as a result of their binding to antithrombin III (5) or, more efficientiy, to antithrombin III-heparin complex. Both prothrombin activation and fibrin formation can thus be inhibited. Apart from antithrombin III several other plasma protease inhibitors exist ( $\alpha 2$-macroglobulin, a 1 -proteinase inhibitor (6)). They ald act in a time-dependent manner. (b) The discovery of protein $C$ (7) bas lead to the understanding of another anticaagulant mechanism. protein c, once activated, functions as an anticoagulant through the selective proteolysis of the protein cofactors, factor $v_{a}$ (8) and factor VII a (9), thus inactivating prothrombinase and the factor-X-converting enzyme. (c) Plasmin cleaves fibrin 1 monomer, a product of the action of thrombin on fibrinogen, thereby preventing the formation of insoluble fibrin (10).

In this paper we report the isolation of a protein fraction from human unbilical cord arteries that instantaneousiy inkibits the activation of prothrombin by prothrombinase, i.e. Eactor $x_{a}$, factor $v_{a}$, phospholipids and $C A^{2+}$. This inhibition leads to a prolongation of the prothrombin time. We demonstrate that the anticoagulant mechanism is unilke those mentioned in this introduction. 
MATERIALS AND METHODS

The chromogenic substrate $\$ 2238$ was purchased from AB Kabi Diagnostica, stockholm, sweden. DEAE-Sephacel, Sephadex G-100 and G-75 were products of Pharmacia. Chemicals for the analytical gel electrophoresis were from Bio-Rad. Human blood was collected by venepuncture in trisodium citrate (final concentration about 13 mM citrate) and centrifuged at $2000 \mathrm{x} g$ for $10 \mathrm{~min}$ at room temperature. The resulting plasma was centrifuged at $10000 \mathrm{x} \mathrm{g}$ for $15 \mathrm{~min}$ in order to obtain platelet-free plasma. A standard pool of platelet-free plasma was prepared by mixing plasma obtained from several healthy donors.

Homogenization of human umbilical cord arteries - Human umbilical cords were obtained within $15 \mathrm{~min}$ after delivery. The arteries were immediately perfused with icecold TBS, subsequently prepared free from the Jelly of warton and homogenized in TBS with a wirl mixer, Braun MX32. A 108 homogenate $(w / v)$ was fractionated as described in Results.

Gel electrophoresis - Gel electrophoresis in the presence of sodiurn dodecyl sulfate was carried out as described by Laemmi (11) on slab gels containing $10 \%$ acrylamide, $0.27 \mathrm{~F}^{\circ} \mathrm{N} \mathrm{N}^{3}$-methylene-bisacrylamide, and 0.18 sodium dodecyl sulfate. The gels were siver-stained according to the method of Merril et al. (12).

Modified prothrombin time test (MPT-test) - The modified prothrombin time test (MPT-test) was carried out as follows. In a siliconized glass cuvette $50 \mu 1$ platelet-free plasma was stirred at 37 OC with $150 \mu 1$ TBS, $25 \mu 1$ of a standard human brain thromboplastin dilution, and 25 u 1 TBS (contral) or $25 \mu 1$ of a fraction of the arterial homogenate. After incubation for 3 min, coagulation was started at time zero with the adation of $250 \mu 1$ $\mathrm{Ca}^{2+}$ buffer $180 \mathrm{mM} \mathrm{NaCl}, 20 \mathrm{mM} \mathrm{CaCl} 2$ and $10 \mathrm{mM} \mathrm{Tris/HCl}$ ph 7.91. Fibrin formation was monitored optically with a Payton Dual Aggregation Module (13). When factor $x_{a}$ was utilized to initiate 
coagulation in the MPT-test, thromboplastin was omitted and 25 " 1 purified factor $x_{a}$ was added together with the 250 w 1 ca $2+$ bufter to the diluted platelet-free plasma.

Modifed thrombin time test (MT-test) - This assay was carried

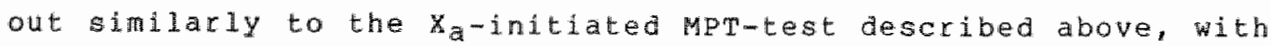
the exception that the $x_{a}$ preparation was replaced by $25 \mu 1$ of purified thrombin.

Proteins - Protease type I and trypsin were obtained from sigma. Thromboplastin was prepared from human brain as described by van Dam-Mieras et al. (14). Factor $x_{a}$, prothrombin and thrombin were purified from citrated bovine blood as described by Rosing et al. (2). Factor $v$ was purified from bovine blood as described by Lindhout et al. (15). Factor $v_{a}$ was obtained by incubation factor $\checkmark$ with thrombin (15). Prothrombin concentrations were calculated using an $M_{r}$ of 72,000 and $A \frac{1}{2} 60$ of 9.6 (17). Factor $x_{a}$ and thrombin concentrations were determined by active site titration (2). other protein concentrations were determined as described by Lowry et al. $(18)$.

Preparation of phospholipid and phospholipid vesicles - Dops and DOPC were prepared as described by Rosing et al. (2). Single billayer vesicles composed of DoPs/DopC (molar ratio 20:80) were prepared by sonication (2). Phospholipid concentrations were determined by phosphate analysis according to the method of Boetcher et a 1 . (19).

Measurement of prothrombin activation - The time course of prothrombin activation was examined at different concentrations of the anticoagulant. Mixtures of $x_{a}$ with ca ${ }^{2+}$, $x_{a}$ with phospholipids and $\mathrm{Ca}^{2+}$ or $\mathrm{x}_{\mathrm{a}}$ with $\mathrm{V}_{\mathrm{a}}$, phospholipids and $\mathrm{Ca}^{2+}$ were stirred with different amounts of the anticoagulant at $370^{\circ}$ in $50 \mathrm{mM} \operatorname{Tris} / \mathrm{HCl}, 175 \mathrm{mM} \mathrm{NaCl}, 0.5 \mathrm{mg} / \mathrm{ml}$ human serum albumin at $\mathrm{pH}$ 7.9. After 3 min, prothrombin activation was started by the addition of prothrombin. At different time intervals, $25 \mu 1$ was 


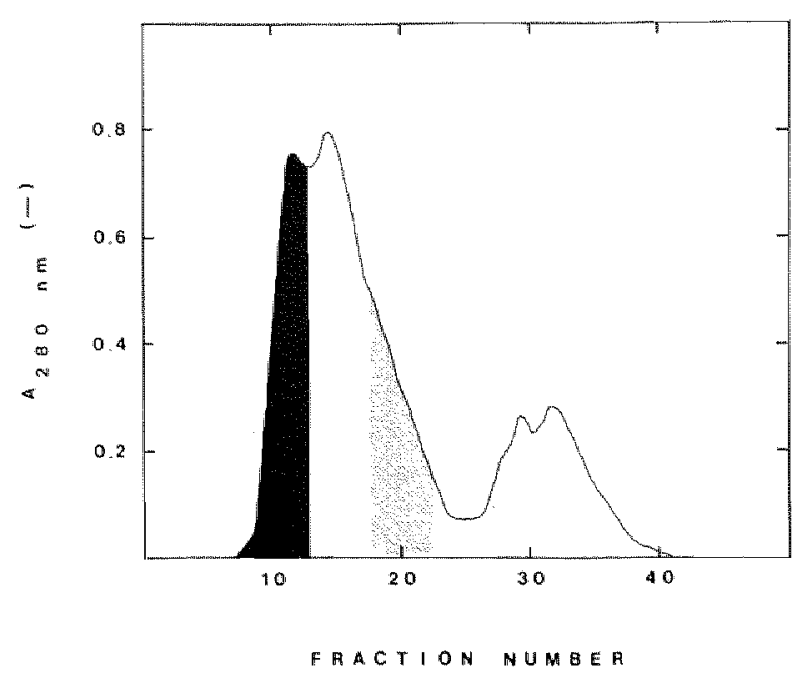

Fig. 1. Gel filtration of the $10,000 x \mathrm{~g}$ supernatant of an umbilical cord artery homogenate on sephadex G-100. Sephadex G-100 column $(1.5 \times 80 \mathrm{~cm})$, which was preequilibrated with TBS. The column was eluted with TBS. Aliquots of the resulting fractions were tested in the MPTtest. Certain fractions (dark-shaded area) express a procoagulant activity and initiate coagulation in the MPT-test without the addition of thromboplastin, factor $x_{a}$, or thrombin. Other distinct fractions (light-shaded area) prolong the clotting time in the MPT-test, using thromboplastin to initiate coagulation. These fractions were pooled and further fractionated.

sampled from the reaction mixture into a cuvette (thermostated at $37{ }^{\circ} \mathrm{C}$ ), containing TBS, $2 \mathrm{mM}$ EDTA and $0.23 \mathrm{mM} \mathrm{s} 2238$ (final volume

$1 \mathrm{ml}$ ). From the absorption change at $405 \mathrm{~nm}$, measured with a Kontron spectrophotometer Jvikon 810 , and a reference curve, made with known amounts of purified thrombin, the amount of thrombin formed was calculated at different concentrations of the anticoagulant. The phospholipids were added as vesicles composed of DOPS/DOPC with a molar ratio of $20: 80$.

RESULTS

Isolation - Eractionation of the supernatant of a $10,000 \times \mathrm{g}$ spin 


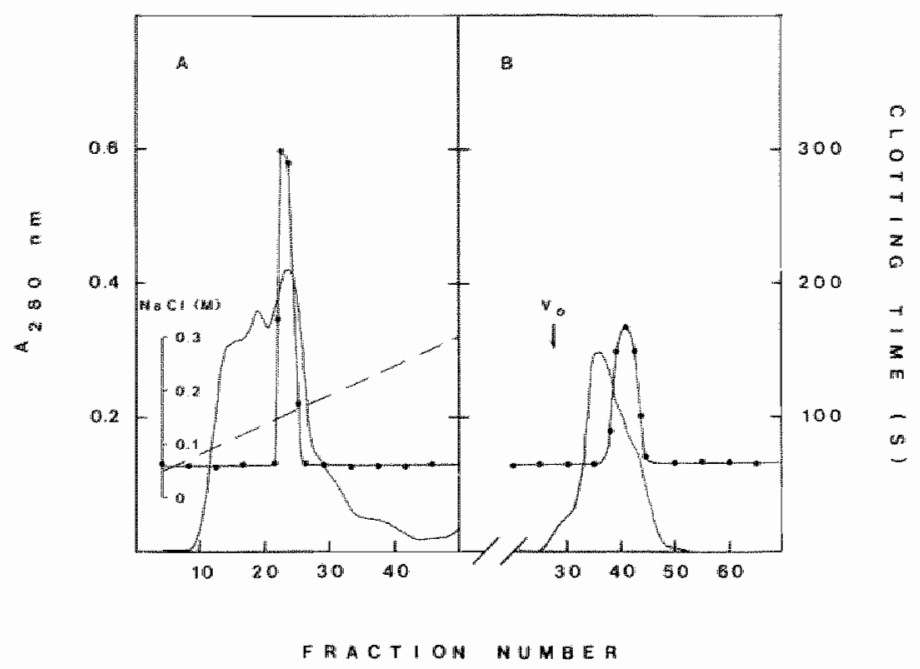

Fig. 2. Chromatography of the anticoagulant on DEAE-Sephacel (A) and Sephadex G-75 (B).

The pool contining the anticoagulant from the sephadex G-100 column was applied to the DEAE-Sephacel. Elution was performed with a $200 \mathrm{ml}$ linear gradient of $50-300 \mathrm{mM}$ Nacl (---). Fractions $(4 \mathrm{ml})$ were collected and assayed for $A_{280}$ (-) and for anticoagulant activity in the MPT-test, using thromboplastin (final concentration $95 \mu \mathrm{g}$ protein/ml) as initiator of coagulation (-). The fractions with anticoagulant activity were pooled, concentrated and subsequently applied to sephadex G-75 (B). Fractions (2ml) were collected and assayed for $\mathrm{A}_{280}(-)$ and for anticaagulant activity (-). Vo represents the void volume of the collumn.

of an umbilical cord artery homogenate on sephadex G-100 results in a reproducible specific elution profile (Fig..1).

The fractions affecting the coagulation system as measured with the MPT-test (see Materials and Methods) are indicated in Fig. I. A procoagulant activity eluted with the void volume. This activity can only be detected in the presence of factor VII in the MPT-test, as indicated by experiments in which human congenital factor VII-deficient plasma was used (data not shown). Therefore this procoagulant must be considered to be tissue thromboplastin. certain fractions expressed a distinct anticoagulant activity. 


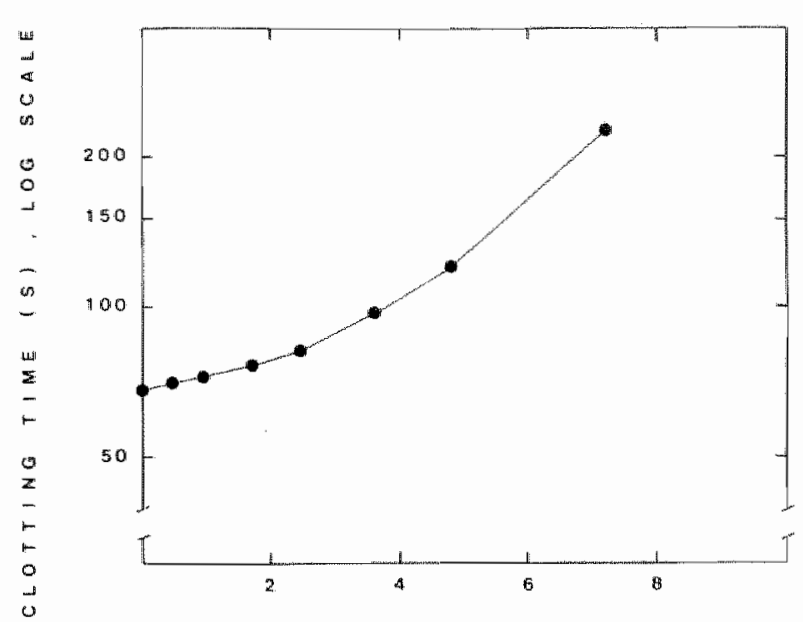

ANTICOAGULANT Q O G

Fig. 3. Dose response of the anticoagulant in the MPT-test. MPT-test. Coagulation was initiated with thromboplastin (final concentration $95 \mu \mathrm{g}$ protein/ml). The control clotting time was $65 \mathrm{~s}$.

These fractions were pooled and further purified with DEAE-Sephacel chromatography (Fig. 2A).

The anticoagulant appeared to bind to the DEAE-Sephacel at $50 \mathrm{mM}$ NaCl and $50 \mathrm{mM}$ Tris/HCl pH 7.9. Elution of the activity with a linear gradient of $\mathrm{NaCl}$ at $\mathrm{pH} 7.9$ was achieved at $150-160 \mathrm{~mm}$ NaCl. The DEAE-Sephacel fractions expressing anticoagulant activity were pooled and submitted to sephadex G-75 geI filtration (Fig. 2B). The column (1.5 $\mathrm{x} 50 \mathrm{~cm}$ ) was equilibrated with TBS. The activity appeared in the fractions which correspond to molecular masses of $30-60 \mathrm{kDa}$.

The MPT-test is used as a quantitative assay for the determination of the amount of anticoagulant activity (Fig.3). We define one unit as the anticoagulant activity that prolongs clotting time in the MPT-test, using thromboplastin lfinal concentration $95 \mu \mathrm{g}$ protein/mil as initiator of coagulation, from its control value of $65 \mathrm{~s}$ to $100 \mathrm{~s}$. With this assay it is calculated that from $10 \mathrm{~g}$ wet arterial tissue $2 \mathrm{mg}$ protein with approximately 


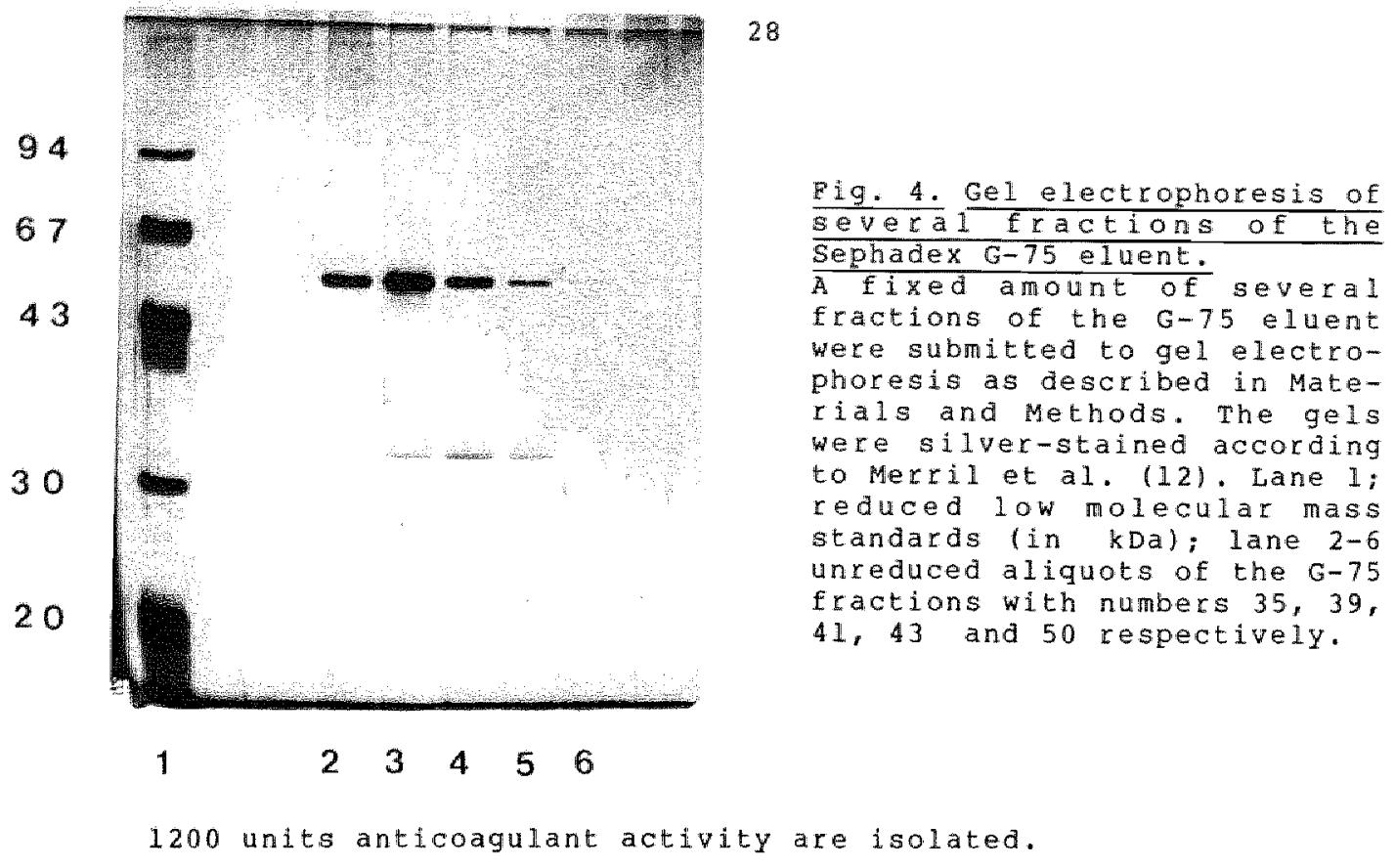

Characterization - Several fractions of the Sephadex G-75 chromatography were tested in the MPT-test and analyzed with SDS-PAGE. The results (Fig.4) suggested that the anticoagulant has a molecular mass of approximately $32 \mathrm{kDa}$. The association between the anticoagulant activity and the 32-kDa band was confirmed by slicing the polyacrylamide gel and subsequent elution of the proteins out of the slices with TBS, containing $0.5 \mathrm{mg} / \mathrm{ml}$ bovine serum albumin. An anticoagulant activity is present only in the aluent of the slice that corresponds to the 32-kDa band. Furthermore this activity is thermolabile at $56^{\circ} \mathrm{C}$ and demonstrates a similar dose-response relationship in the MPT-test as the starting material.

The G-75 fractions, containing the peak anticoagulant activities were pooled and used for further characterization of the anticoagulant. Incubation of the anticoagulant at $56{ }^{\circ} \mathrm{C}$ rapidly decreases its activity until after $2 \mathrm{~min}$ no activity can be measured. The anticoagulant loses its activity completely within 2 h upon incubation at $37{ }^{\circ} \mathrm{C}$ with protease type I, whereas trypsin hardly inactivates the anticoagulant after an incubation period of 3 h (Fig.5). The concentrations of protease type $I$ and trypsin, used 


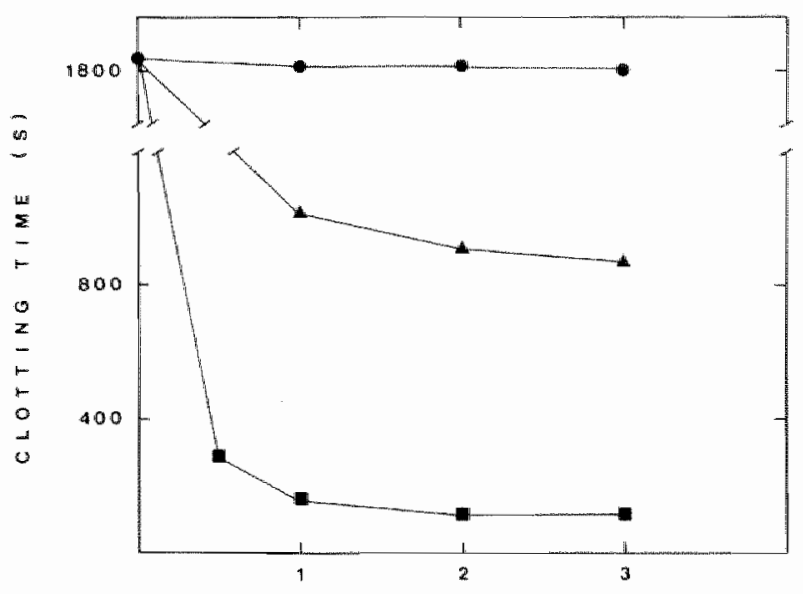

HOU R S

Fig. 5. The effect of proteolytic enzymes on the activity of the anticoagualant.

The anticoagulant was incubated at $37{ }^{\circ} \mathrm{C}$ with protease type I ( final concentration 0.11 units/mll, trypsin $6 \Delta$, final concentration 88 BAEE units/ml) and without proteolytic enzymes ( ) . At the time points indicated, $5 \mu \mathrm{I}$, containing $6 \mu \mathrm{g}$ protein of the anticoagulant, was removed from the reaction mixture and added to a MPTtest. Clotting was initiated with thromboplastin (final concentration $18 \mu \mathrm{g}$ protein/ml). Control clotting time was $110 \mathrm{~s}$. The units given in this legend for the proteolytic enzymes are calculated from the values supplied by the manufacturer.

in these experiments, completely inactivate $2.5 \mathrm{nM}$ thrombin in 15 min (data not shown). The amounts of protease type I and trypsin, carried over from the reaction mixtures to the MPT-test, have no effect on the control clotting time.

Similar material could be obtained from human, bovine, rabbut and rat aorta and from a strongly wascularized tissue like lung. It could not be obtained from a poorly wascularized tissue like human diaphragm. 


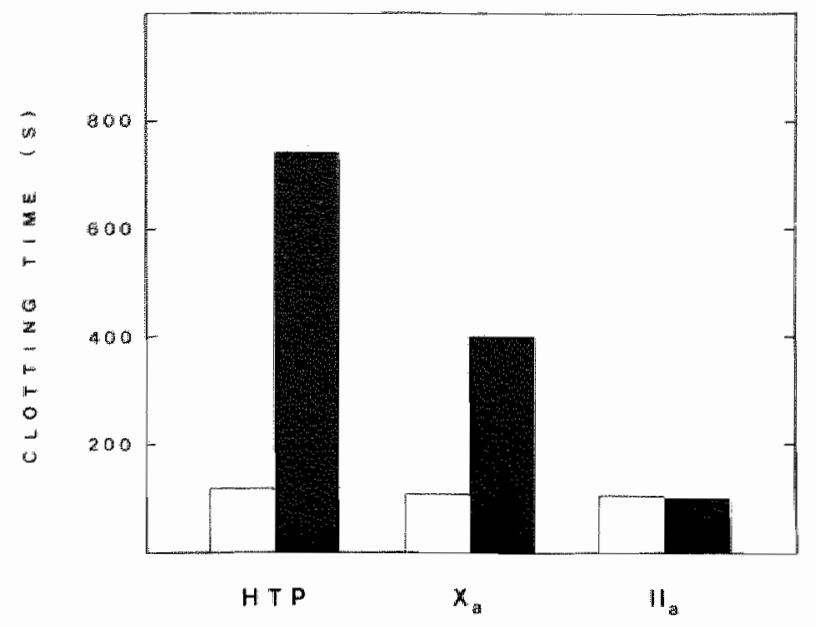

Pig. 6. The effect of the vascular anticoagulant on the clotting times, induced in the MPT-test by either thromboplastin, factor $x a$ or thrombin.

The concentrations of the initiators of coagulation (thromboplastin $18 \mathrm{\mu g}$ protein/ml, $1.5 \mathrm{nM}$ factor $\mathrm{x}_{a}$ or 0.4 nM thrombin) were chosen such to give control clotting times of about $110 \mathrm{~s}$ (open bars). When factor xa was used, phospholipids vesicles (final concentration $10 \mu M$ ), composed of DoPS/DOFC (molar catio, 20:80) were added to the reaction mixture. Clotting times induced by the indicated agents in the presence of $3.5 \mu \mathrm{g}$ protein of the anticoagulant are presented by the black bars.

Mode of action - The Mpt-test is prolonged in the presence of the anticoagulant (Fig. 6) both when triggered with thromboplastin and when started with factor $x_{a}$. Thrombin-induced coagulation, however, $1 \mathrm{~s}$ not inhibited.

becase of these findings we investigated the effect of the anticoagulant on the conversion of prothrombin to thrombin by Eactor $x_{a}$, Eactor $V_{a}$, phospholipids and $\mathrm{Ca}^{2+}$. under the experimental conditions mentioned, thrombin formation is inhibited by the anticoagulant in a dose-dependent way (Fig. 7A). The activation of prothrombin by factor $x_{a}$, phospholipids and ca $2+$ in the absence of factor $V_{a}$ can also be inhibited by the anticoagulant (fig. 7B). However this inhibition is not observed if the 


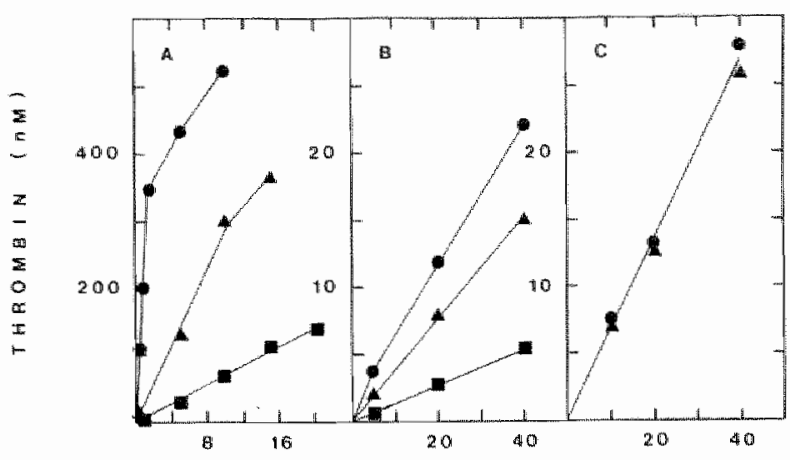

M $\|$ U U T E S

Fig. 7. The effect of the anticoagulant on prothrombin activation by $X_{a}$ with Va, phospholipids and Caz+; $X_{a}$ with phospholipids and $\mathrm{Ca} 2+$ and $\mathrm{X}$ a with $\mathrm{Ca}^{2+}$

The reaction mixtures contained: (A), I uM prothrombin, $0.3 \mathrm{nM} \mathrm{X}, 0.6 \mathrm{nM} \mathrm{V}_{\mathrm{a}}, 0.5 \mu \mathrm{M}$ phospholipids and $10 \mathrm{mM}$ Cacl 2 with $12.0 \mu \mathrm{g} / \mathrm{ml}$ anticoagulant $($ ), $4.8 \mu \mathrm{g} / \mathrm{ml}$ anticoagulant $(\Delta)$ and without anticoagulant $(\bullet)$ (B) $1 \mu \mathrm{M}$ prothrombin, $10 \mathrm{nM} \mathrm{x}_{\mathrm{a}}, 0.5 \mu \mathrm{M}$ phospholipids and 10 $\mathrm{mM} \mathrm{CaCl} 2$ with $2.4 \mu \mathrm{g} / \mathrm{ml}$ anticoagulant ( ), 0.48 $\mu \mathrm{g} / \mathrm{ml}$ anticoagulant $(\boldsymbol{A})$ and without anticoagulant (-). (C) $1 \mu \mathrm{M}$ prothrombin, $75 \mathrm{nM} \mathrm{x}_{\mathrm{a}}$ and $10 \mathrm{nM} \mathrm{CaCl} 2$ with $120 \mathrm{Mg} / \mathrm{ml}$ anticoagulant $(\Delta)$ and without anticoagulant (-). At the times indicated samples were removed and thrombin was determined as described in materials and methods.

activation takes place in the absence of phospholipidg (Fig. 7C).

\section{DISCUSSION}

In this paper we describe the isolation procedure of a novel anticoagulant from a homogenate of human umbilical cord arteries. The anticoagulant has been discovered by its ability to prolong the clotting time in a prothrombin time test. The anticoagulant activity became measurable after sephadex G-100 fractionation of the arterial homogenate. From further isolation procedures we assume this actity to be associated with a water-soluble substance(s), that carries an overail negative charge at pH 7.9 . 
Analysis of the sephadex G-75 fractions (the final purification step we performed so farl with gel electrophoresis shows a positive correlation between the intensity of the 32-kDa band and the prolongation of the clatting time as measured with the MPrtest. The identity of the $32-k D a$ band with the anticoagulant activity is demonstrated unambiguously since the anticoagulant activity can only be eluted from the site of the 32-kDa band on the polyacrylamide gel. From these findings and the fact that the anticoagulant rapidiy loses its activity upon incubation at 56 oc and proteolytic enzymes can destroy its activity, we assume the anticoagulant activity to be expressed by a single protein with an apparent molecular mass of $32 \mathrm{kDa}$.

Trypsin, in contrast to protease type $I$, is a poor inactivator of the anticoagulant. This suggests that the anticoagulant possesses a small number of lysine and arginine residues that are accessible for trypsin.

We studied the nature of the anticoagulant activity by initiating coagulation in different ways. Clotting, induced by either the vascular procoagulant, thromboplastin, or factor $x_{a}$, is inhibited by the anticoagulant; thrombin-induced clotting, on the other hand, is not. From these findings we conclude that the anticoagulant interferes with thrombin formation, not with thrombin action.

To study the anticaagulant mechanism of the compound further we have used prothrombinase reconstituted from purified coagulation factors and phospholipids (2). Under the experimental conditions mentioned, the anticoagulant can inhibit the activation of prothrombin by complete prothrombinase (factor $x_{a}$, factor $v_{a}$, phospholipids, Ca2t) but not by free factor $x_{a}$ (factor $x_{a}, C a 2+$ ). The time courses of prothrombin activation in the presence of the anticoagulant indicate an instantaneous inhibition of prothrombin activation, that remains constant in time. Therefore, we conclude that the anticoagulant does not act by phospholipase or by proteolytic activity. The fact that the activation of prothrombin by factor $x_{a}$ and $c 2^{2+}$ is not affected by the anticoagulant at all strongly indicates that the anticoagulant mechanism of the 
vascular compound differs from that of the well known plasma protease inhibitors such as antithrombin III. since walker at al. (8) have demonstrated that activated protein $C$ does not inhibit prothrombin activation by factor $x_{a}$, ca $2+$ and phospholipids, it can also be concluded that our compound is not protein $C$ either. Preliminary binding studies indicate that the vascular anticoagulant probably interferes with the lipid binding of factor $x_{a}$ and/or prothrombin. Whether the ability of the anticoagulant to inhibit prothrombin activation completely accounts for its prolonging effect on the prothrombin time remains to be established. The fact that we could find this inhibitor in various types of arteries but not in a poorly vascularized tissue may indicate that we have found a physiological modulator of hemostasis and thrombosis, active at the vascular level.

\section{ACKNOWLEDGEMENTS}

The athors wish to thank J.Govers-Riemslag and J.Eranssen for providing the purified coagulation factors, M. Molenar for typing this manuscript and M. Rand for her Linguistic help.

\section{I TERATURE}

1. Jackson. C. M. \& Nemerson, Y. 1980. Annu. Rev. Biochem. 49, $765-811$.

2. Rosing, J., Tans, G., Govers-Riemslag, J. W. P., Zwal, R. F. A. Hemker, H. C. 1980 . J. Biol. Chem. 255, 274-283.

3. Van Dieijen, G., Tans, G., Rosing, J. Henker, H. C. 1981. J. Biol. Chen. 256, 3433-3442.

4. Rosenberg, R. D. Rosenberg, J. S. 1984. J. Clin Invest. $74,1-6$.

5. Kurachi, K., Fujikawa, R., Schmer, G. Davie, E. W. 1976. Biochemistry $15,373-377$.

6. El1is, V., Scul1Y, M., Macgregor, I. Kakkar, V. 1982. Biochim. Biophys. Acta 701, 24-31.

7. Stenfla, J. 1976. J. Biol. Chem. 251, 355-363. 
g. Walker, E. J." Sexton, P. W. E Emson, C. T. 1979. Biochim. Biophys. Acta 571, 333-342.

9. vehar, G. A. Davie, E. W. 1980. Biochemistry 19, 401-409. 10. Nobse1, H. L. 1981, Nature (Lond.) 291, 165-167.

11. Laemml1, U. K. 1970. Nature (Lond.) $227,680-685$.

12. Merril, C. R., Goldnan, D. \& Van Reuren, M. L. 1982. Electrophoresis $3,17-23$.

13. Hornstra, G. 1981. Phil. Trans. R. Soc. Lond B Biol. Sci. $294,355-371$.

14. van Dam-Mieras, M. C. E., Muller, A. D., van Dieijen, G. \& Hemker, H. C. 1984. Methods of Enzymatic Analysis, vol. 5, pp. 352-365, Verlag Chemie GmbH, Weinheim.

15. Windhout, T., Govers-Riemslag, J. G., van de wart, P., Hemker, H. C. \& Rosing, J. 1982. Blochemistry 21. 45945502 .

16. Owen, W. G., Emson, C. T. \& Jackson, C. M. 1974. J. Biol. Chem. 249, 594-605.

17. Nesheim, E. M., MyrmeI, K. H., Hibbard, L. \& Mann, K. G. 1979. J. Biol. Chem. 254, 508-517.

18. Lowry, O. H., Rosebrough, N. V., Farr, A. L. \& Randall, R. J. 1951. J. Biol, Chem. 193, 265.

19. Bbttcher, C. J. F., van Gent, C. M. \& Pries, C. 1961. Anal. Chim. Acta 24, 203-207. 


\section{CHAPTER 3}

PURIFICATION AND CHARACTERTZATION OF A NOVEL PROTEIN FROM BOVINE AORTA, THAT INHIBITS COAGULATION

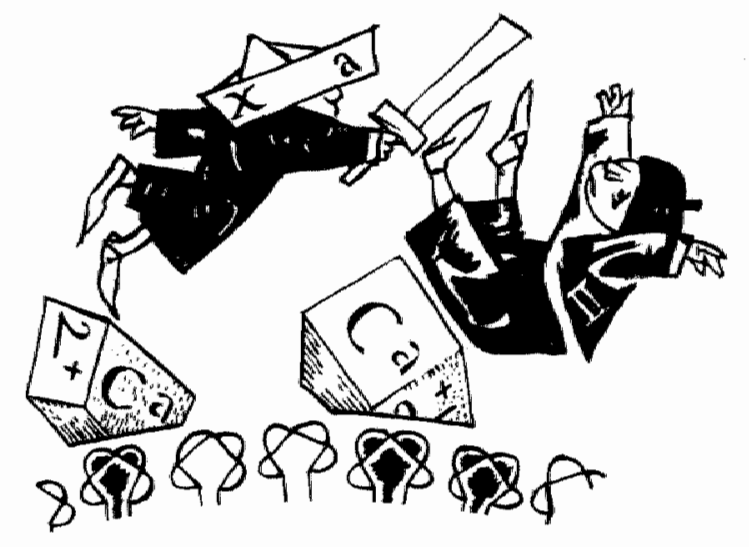



PURIFICATION AND CHARACTERIZATION OF A NOVEL PROTEIN FROM BOVINE AORTA, THAT INHIBITS COAGULATION

Reutelingsperger, C.P.M., Kop, J.M.M., Hornstra, G., and Hemker, H.C.

\section{SUMMARY}

A novel inhibitor of blood coagulation has been isolated from the intima of bovine aorta. The inhibitor (VAC) is purified to an active fraction, that contains two coomassie Blue staining bands $\left(M_{r}=34,000\right.$ and $M_{r}=32,000$, as judged by sodium dodecyl sulfate polyacrylamide electrophoresis). Both bands are single chain proteins, having no glycoprotein features. Furthermore, they do not contain any detectable $y$-carboxyglutamic acid residues. Both proteins have an identical isoelectric pH of approximately 4.5. VAC binds in the presence of calcium-ions to a bilayer consisting of $20 \%$ dioleoyl phosphatidylserine and 808 dioleoyl phosphatidylcholine with a $K_{d}=6 \times 10^{-9} \mathrm{M}$. The binding is depended on the calcium concentration: half saturation of binding occurs at a calcium concentration of $0.8 \mathrm{~mm}$. The binding is completely reversible with EDTA. Furthermore the phospholipid to VAC ratio at saturation was $n=112$ and $n=32$ moles/mole for $0.5 \mathrm{mM} \mathrm{Ca} 2+$ and $2 \mathrm{mM} \mathrm{Ca}{ }^{2+}$, respectively. Binding does not occur between VAC and pure dioleoyl phosphatidylcholine.

In a system with purified coagulation factors VAC inhibits the activation of prothrombin by factor $x_{a}$ and calcium only in the presence of negatively charged phospholipids. VAC decreases the $V_{\max }$ and increases the $K_{m}$ of the factor $x_{a}$-catalyzed prothrombin activation. Based on these results we conclude that we have purified from bovine aortic intima an anticoagulant protein, which exerts its activity through a calcium dependent binaing to negatively charged phospholipids, and thus interfering with the formation of prothrombinase. 


\section{IMTRODUCTION}

The enzymes, active in the process of blood coagulation, belong to the class of serine-proteases, and circulate in the blood as nonenzymatic precursors, the zymogens $(1-3)$. The activation of such a zymogen proceeds in a proteolytic process, in which an already activated coagulation Eactor cleaves a specific bond of its substrate, a zymogen (4). The rate of this reaction is extremely low, but can be greatly enhanced by the presence of certain nonenzymatic cofactors, which can be divided into protein cofactors and negatively charged surfaces. The factor $x_{a}-c a t a-$ lyzed activation of prothrombin, for example, which is a well documented reaction in blood coagulation, is accelerated by the protein cofactor $V_{a}$ and by negatively charged phospholipids $(5-7)$.

The procoagulant reactions are regulated by physiological anticoagulants, which can be classified, on basis of their mechanisms of action, into:

1) Inhibitors of the serine-proteases. Antithrombin III, $2^{-}$ macroglobulin, and $\alpha_{\text {l-antitrypsin }}$ can be assigned to this group of anticoagulants $(8-10)$.

2) Inhibitors of the nonenzymatic cofactors. Activated protein $c$ proteolytical1y cleaves the protein cofactors $V_{a}$ and VIIIa, and thereby inhibits the prothrombinase complex and the intrinsic factor $x$ activation, respectively $(11,12)$. Some phospholipases $A_{2}$ and some Lupus anticoagulant species, which show a calcium independent binding to negatively charged phospholipids, have been described as anticoagulants, inhibiting the phospholipid dependent procoagulant reactions $(13,14)$. However, at the monent, activated protein $C$ is the only physiologically relevant anticoagulant, able to be classified into this second group.

Recently, we have discovered in human umbilical cord arteries a protein $(M r=32,000)$, with an anticoagulant activity, which suggested a classification of this protein into the above mentioned second group (15). A similar protein has now been found in bovine aortic intima. This paper reports on the purification of 
this protein, which we have termed VAC (vascular anticoagulant). It is shown that VAC binds reversibly in the presence of calcium ions to negatively charged phospholipids, and thereby inhibits the phospholipid dependent activation of prothrombin by factor $x_{a}$. Furthermore, VAC has neither a phospholipase- nor a proteolytic activity. Based on these findings, we conclude that VAC is a novel type of anticoagulant, which can be assigned to the above mentioned second group of anticoagulants. Part of this work has been presented earlier (16).

\section{MATERIALS AND METHODS}

Bovine aorta's were removed from the animals within half an hour after they had been slaughtered. Bovine blood was collected in trisodium citrate (final concentration 0,388 ) and centrifuged at: $2,000 \times \mathrm{g}$ for 10 minutes at room temperature. The platelet poor plasma was recentrifuged for 15 minutes at $10,000 \times 9$, to obtain PFP. Hydroxylapatite and the chemicals for the analytical SDS-PAGE were from Bia-Rad (Richmond, California). Sephadex G-75, DEAE-Sephacel, and the Low Molecular Weight calibration kit were purchased from Pharmacia (oppsala, Sweden). The chromogenic substrates $\$ 2238$ and $\$ 2337$ were from Kabi Vitrum. Diaflo PM-10 ultrafiltration devices and membranes were obtained from Amicon.

Purification of VAC - After the arta's had been removed from the animals, they were rinsed thorougly with TBS. The intima was dissected from the aorta and homogenized with a whirl mixer, Braun MX32, in TBSE, containing soybean trypsin inhibitor (16 $\mathrm{mg} / \mathrm{l}$ ) and benzamidine $(1.57 \mathrm{~g} / \mathrm{l})$. The $20 \mathrm{~s}$ (w/V) homogenate obtained Erom 8 aorta's was centrifuged at 100,000 x $\mathrm{g}$ for 60 minutes. The supernatant was brought to 35 saturation with solld ammonium sulfate, stirred for 30 minutes, and centrifuged for 20 minutes at $12,000 \times g$. This procedure was repeated with the resulting supernatant at 90 o amonium sulfate saturation. The pellet was suspended in a small volume of TBS and ailalyzed against TBS, containing benzamidine $(1.57 \mathrm{~g} / 1)$. The dialyzed 
fraction was applied to a hydroxylapatite column $(3 \times 5 \mathrm{~cm})$, which had been equilibrated with TBS. After washing, VAC was eluted from the column with a $200 \mathrm{ml}$ linear gradient of $0-500 \mathrm{mM}$ sodium phosphate buffer ( $\mathrm{pH} 7.5)$. The VAC containing fractions were pooled and dialyzed against $50 \mathrm{mM} \mathrm{NaCl}, 20 \mathrm{mM} \mathrm{Tris} / \mathrm{HCl}$, and $\mathrm{pH}$ 7.5. Which buffer was also used to equilibrate a $3 \times 5 \mathrm{~cm}$ DEAE-Sephacel column. The dialyzed VAC-pool was applied to the DEAEcolumn. VAC, bound to this column, could be eluted with a $200 \mathrm{ml}$ linear gradient of 50-300 mM NaCl in $20 \mathrm{mM} \mathrm{Tris/HCl,} \mathrm{pH} 7.5$. The eluted VAC was concentrated in an Amicon concentration device, using a PM-10 ultrafiltration membrane. Finally, the VAC-concentrate was submitted to gel filtration on a $3 \times 160 \mathrm{~cm}$ Sephadex G-75 column, which had been equilibrated with TBS. The eluent was collected in fractions of $2 \mathrm{ml}$ and stored at $-70 \mathrm{OC}$. All purification procedures were carried out at $0-4{ }^{\circ} \mathrm{C}$.

Assay of VAC activity - A modified prothrombin time test (MPTtest) was used to assay vac-activity throughout the purification procedure. The test is essentially similar to that described for the human anticoagulant (15), the only difference being the use of bovine PFP and bowine thromboplastin (the BTP batch contained $3.6 \mathrm{mg}$ protein/m1 and $3.4 \mathrm{~mm}$ phospholipid). For quantification of VAC-activity we arbitarily defined one vac-unit as the amount of VAC that prolongs the clotting time in the MPT-test, using BTP diluted $1: 75$, from the control value of $65 \mathrm{~s}$ to $100 \mathrm{~s}$.

Measurement of rate of prothrombin activation - purified bovine factor $\mathrm{X}_{\mathrm{a}}$, CaCl2, phospholipid vesicles, composed of 808 DopC and 208 DOPS were stirced in TBSA for 3 minutes at $37{ }^{\circ} \mathrm{C}$. The activation was started with the addition of prothrombin (final concentrations are indicated in the legends to the figures). At different time points 50 M aliquots were sampled from the mixtures and added to plastic cuvettes thermostated at $37{ }^{\circ} \mathrm{C}$ and containing 950 w TBSE with $0.23 \mathrm{mM}$ s2238. From the absorbance change at $405 \mathrm{~nm}$, recorded with an Aminco DW-2 spectrophotometer, the amount of activated prothrombin in the reaction mixture as a 
function of the time was determined, using a calibration curve made with known amounts of purified bovine thrombin. The rate of prothrombin activation was calculated from samples taken after different time intervals.

Proteins - The vitamin k-dependent factors prothrombin and factor $\mathrm{x}_{2}$ were purified from bovine-citrated plasma as described by stenflo (17). After barium citrate adsorption and elution, ammonium sulphate fractionation and DEAE-sephadex chromatography, two pratein pools were obtained, containing a prothrombin-factor Ix mixture and factor $x$ respectivily. Factor $x$ was obtained by the method of Fujikawa et al. (18) and activated, using RVV-X (19). Prothrombin was separated from factor IX by heparin agarose affinity chromatography (Fujikawa et al. 20). The prothrombin containing fractions from the heparin-agarose column were pooled and further purified using the method of owen et a 1 (21). Prothrombin and factor $x_{a}$ concentrations were determined as described by Rosing et al. (7).

BTP was prepared using a standard method as described by van DamMieras et al. (22). Protein concentrations, except for prothrombin and factor $x_{a}$, were determined according to Lowry et al. (23).

Phospholipid and phospholipid (large volume) vesicle preparation and phospholipid bilayer preparation on silicon slides - DopC and Dops were prepared as described by Rosing et al. (7). Single bilayer vesicles of DOPC and DOPS were prepared by sonication as described in (7). Phospholipid large volume vesicles, composed of: $20 \%$ DOPS/80\% DOPC were prepared according to the method described by van de wart et al. (24). Phospholipid concentrations were determined by phosphate analysis according to Bttcher et al. (25). phospholipid bilayers were stacked on silicon slides in a preparative Langmuir trough (Landa, type EW-1) at a constant surface pressure of 40 dynes/cm and at a dipping speed of 2 $\mathrm{mm} / \mathrm{min}$. The subphase consisted of 50 , M Ca $2+$ in filtered and deionized water (Milipore). The temperature was kept at $18^{\circ} \mathrm{C}$. 
Further detalis of this technique have been published (26).

Protein binding determination - The binding of WAC to a phospholipid bilayer was examined with an ellipsometric technique, which has been described in detail earlier (26). In brief, monochromatic light (spectra-Physics Laser model, $\lambda=632.8 \mathrm{~nm}$ ) was reflected against a silicon slide covered with a deposited or adsorbed layer. Before and after reflection, two polarizing prisms were passed and automatically rotated, such that the light intensity reaching the photodiode is kept minimal. From the changes in the position of both polarizers, the refractive index, $n$, and the thickeness, $d$, of the layer can be calculated. The mass of the substance deposited on the silde $(r$, the two - dimensional concentration) can be calculated from the values of $n$ and $d$ by using a modified Lorentz - Lorenz relation:

$$
r=3 d\left(n^{2}-n_{b^{2}}\right) /\left\{\left(n^{2}+2\right)\left(r\left(n_{b^{2}}-1\right)-v\left(m_{b}^{2}-1\right)\right\}\right.
$$

where $r$ and $v$ are the specific refractivity and the partial specific volume of the deposited substance, respectively. $\mathrm{n}_{\mathrm{b}}$ is the refractive index of the buffer. Equilibrium binding data were analyzed from double-reciprocal plots according to the following equation:

$$
1 / \Gamma^{\circ}=\left(\mathbb{R}_{\mathrm{a}} / \Gamma_{\max }\right)(1 / \mathrm{c})+1 / \Gamma_{\max }
$$

where $c$ is the concentration of VAC in the solution. The dissociation constant $\mathrm{K}_{\mathrm{d}}$ and the maximal binding capacity $r$ max were caloulated from the horizontal and vertical intercepts of a double reciprocal plot, respectively.

Binding of prothrombin and factor $x_{a}$ to large volume vesicles was assessed as described by Wan de Wart et al. (24). Mixtures of 1 arge volume vesicles, $\mathrm{CaCl}_{2}$, prothrombin or factor $x_{a}$, and varying amounts of VAC were incubated for 5 minutes at $37^{\circ} \mathrm{C}$. prior to and after centrifugation for 30 minutes at $30,000 \mathrm{x}$ and $20^{\circ} \mathrm{C}, 25 \mu 1$ samples were taken to determine total protein and 
unbound protein, respectively. The phospholipid concentration in the supernatant was less than $0.1 \%$ of the total amount added. Prothrombin concentration was determined with Echis Carinatus venom as described by van Dieijen et al. (27). These protein assays were not influenced by phospholipid carried over from the reaction mixture prior to centrifugation, nor by the carry over of VAC, when present in the reaction mixture. Prothrombin binding and factor $x_{a}$ binding to the large volume vesicles was reversible - as shown by the addition of EDTA. Determination of bound protein by resuspending the pelleted vesicles in EDTA and an second spin down, established the recovery of total protein to be virtually $100 \%$. All binding experiments were carried out in a buffer containing $50 \mathrm{mM} \mathrm{Tris} / \mathrm{HCl}, 100 \mathrm{mM} \mathrm{NaCl}, 0.5 \mathrm{mg}$ ovalbumin/ ml, and $3 \mathrm{mM} \mathrm{CaCl}_{2}, \mathrm{pH} 7.5$.

SDS-RAGE - Slab gel electrophoresis in the presence of SDS was carried out as described by Laemmil (28) on the gels containing 10 acrylamide, $0.27 \mathrm{~N} / \mathrm{N}^{3}$-methylene bisacrylamide and $0.1 \%$ SDS. $58 \quad \beta$-mercaptoethanol was present in disulfide bond reduced gel samples. The gels were stained with 0.258 Coomassie Blue $R-250$ in $50 \%$ ethanol, $15 \%$ acetic acid and destained in 108 ethanol, $10 \%$ acetic acid. Gels were also stained using schiff's reagent prepared from basic fuchsin (Merck) according to the method of segrest (29).

Electrofocusing - Isoelectric pH determination of proteins was performed with ready-prepared thin-layer polyacrylamide gels containing Ampholine carrier ampholytes (PAGplates, LKB) in a pH range between 3.5-9.5, according to the manual of the manufacturer. The $\mathrm{pH}$ gradient in the gel was determined imediately after the termination of the electrofocusing by slicing a strip of the gel along the ine between the anode and the cathode. The ampholytes were eluted from each slice with distilled water and the pH of the water was measured.

V-Carboxy glutamic acid determination - GLA-determination was 


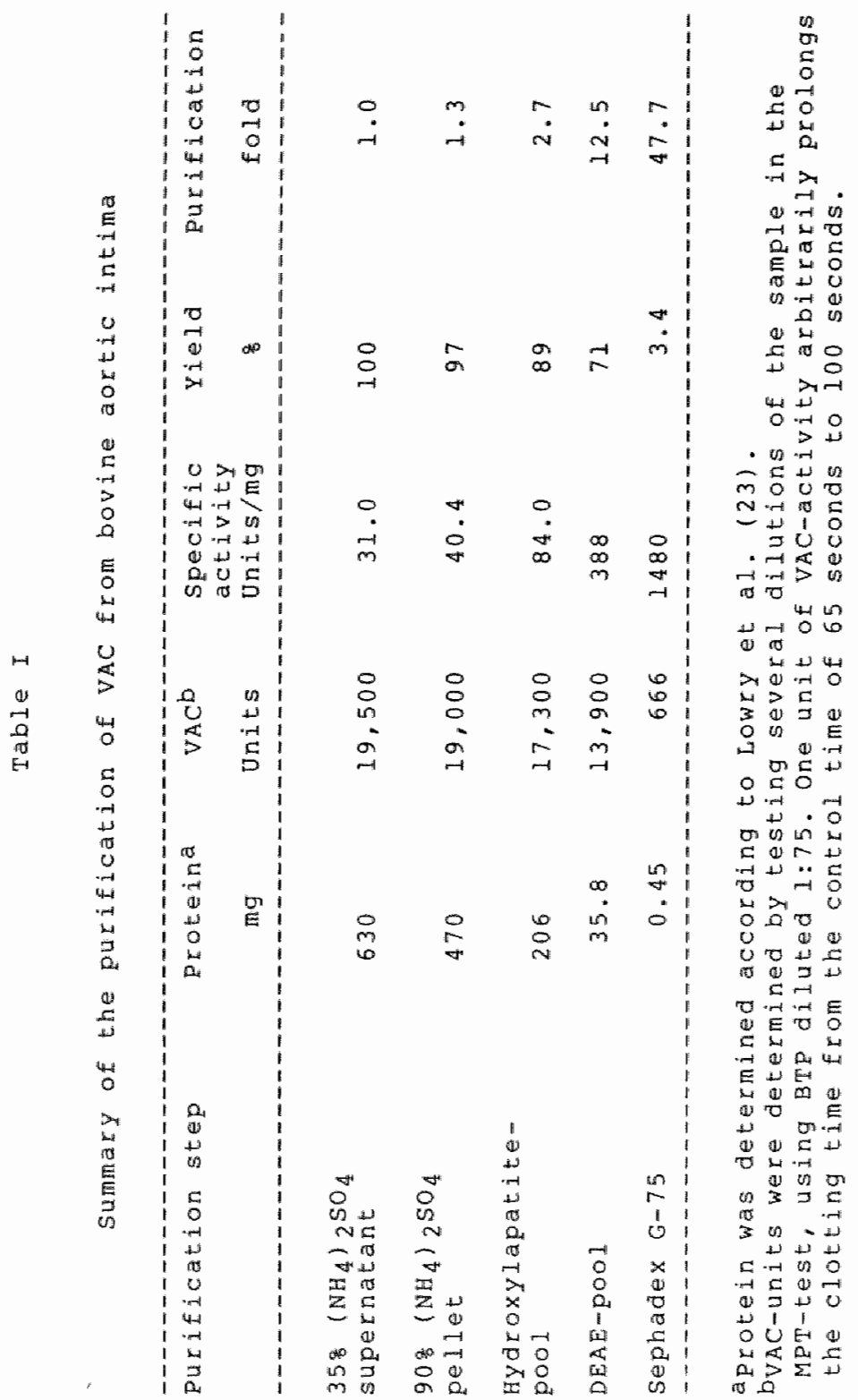


performed with high pressure liquid chromatography using a nucleosil $5 \mathrm{sB}$ column (Chrompack) according to the method of Kuwada and Katayama $(30)$.

\section{RESULTS}

Isolation and purification of VAC - Using the methods employed for the isolation of the human anticoagulant (15), it appeared that the water-soluble part of a bovine aortic homogenate also contains an anticoagulant activity with properties very similar to those of the human anticoagulant. For purification of this bovine anticoagulant, however, an extension of the isolation procedure was required. The procedure together with its results is summarized in table 1 . The presence of a procoagulant activity in the homogenate and in the $100,000 \mathrm{x} g$ supernatant prevents quantification of VAC-activity in these fractions. The procoagum lant activity precipitates with ammonium sulfate at 35 saturation, while VAC remains in solution. The 35 ammonium sulfate supernatant is chosen arbitrarily to contain loos of VAC-activity. The anticoagulant, that binds to a hydroxylapatite column, elutes from this column at approximately $150 \mathrm{mM}$ phosphate and $\mathrm{pH}$ 7.5. At low ionic strength VAC binds to DEAE-Sephacel and elutes from the DEAE at $150-180 \mathrm{mM} \mathrm{NaCl}$ and $\mathrm{pH} 7.5$. The final purification step involves a sephadex $G-75$ gel filtration. VAC elutes from the sephadex columin in fraction that corresponds with the molecular weight range of $30,000-40,000$ daltons, as assessed with globular proteins with known molecular weights. The recovery of VAC-activity in the purified fraction, 153.4 . VAC stored at $-70^{\circ} \mathrm{C}$ is stable for at least six months.

Chemical characterization of VAC - From analytical sDS-gAGE it appeares that two polypeptides $\left(M_{\mathrm{r}}=32,000\right.$ and $\left.M_{\mathrm{r}}=34,000\right)$ copurify with the VAC-activity (fig. 1). The association of the vac-activity with the $32-k$ DA band and/or $34-k$ Da bana 1 s established by eluting the bands from the gel. only from the sites corcesponding with the $32-k$ Da bands and $34-k$ Da bands the VAC-activity could 


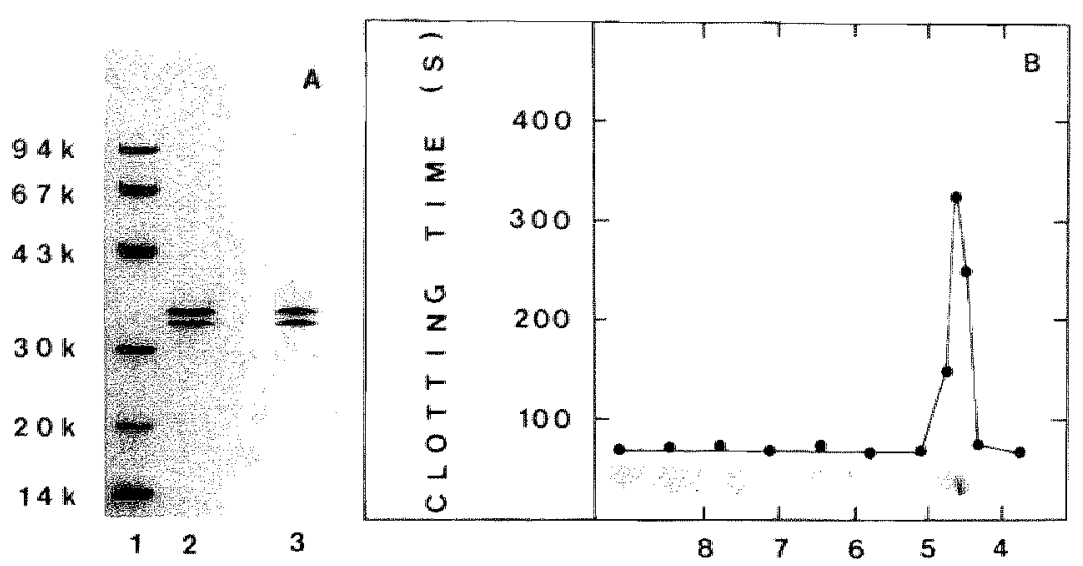

N U M B ER

p H

Eig. 1. Analytical SDS-PAGE (A) and isoelectric pH determination (B) of (VAC).

SDS-PAGE with slab gels containing $10 \%$ acrylamide, $0.27 \%$ $\mathrm{N}, \mathrm{N}^{3}$-methylenebisacrylamide, and 0.18 SDS was carried out according to Laemmli (28). The gel is as follows: 1) Reduced molecular welght standards (in Da). 2) $25 \mathrm{mg}$ reduced purified VAC. 3) $25 \mu \mathrm{g}$ unreduced purified VAC. The gel was stained with caomassie Brilliant Blue and destained as described in materials and methods. $5 \mu \mathrm{g}$ of VAC was submitted to isoelectric focussing (B). After which, the gel was either fixed for 30 minutes in 0.7 o trichloric acid and subsequently stained with Coomassie Brilliant Blue, or cut into slices, which were eluted overnight at $4^{\mathrm{o}} \mathrm{C}$ with TBSA. The eluents were tested in the MPT-test, using BTP (f.c. $54 \mu \mathrm{g}$ protein/ml and $51 \mu \mathrm{M}$ phospholipid).

be recovered. However, due to their close proximity on the gel, we do not know whether the vac-activity is associated with only one band or with both bands.

Both polypeptides appear to have the same isoelectric pH of approximately 4.5 (fig. 1). This is confirmed by elution of the 4.5-band out of the PAglate and subsequent anallsis of the eluent with SDS-PAGE.

vurthermore, both polypeptides are single chain proteins, which have no glycoprotein features, e.g. they do not stain with a 
schiff's reagent and they do not bind to concanavalin $A$. Basic hydrolysis of the polypeptides and subsequent analysis of the amino acid contents on HPLC, using a nucleosil $5 \mathrm{SB}$ column, demonstrates no detectable GLA-residues to be present.

similar to the human anticoagulant (15), VAC-activity is abolished upon incubation at $56{ }^{\circ} \mathrm{C}$ for two minutes, and destructed in a time dependent way upon proteolytic digestion with protease type $\mathrm{I}$.

The interaction of VAC with phospholipids - Preliminary experiments, in which binding of VAC to negatively charged large volume phospholipid vesicles was studied qualitatively, have indicated a reversible binding of VAC to these phospholipids. A quantitative determination of the phospholipid binding of VAC was performed with the automated ellipsometer. This approach has already been described in a study of the phospholipid binding of prothrombin (26). Equilibrium binding of VAC to phospholipids was studied with a bilayer of $20 \%$ Dops and 808 DOPC, stacked on a silicon slide. Fig. 2 shows a double reciprocal plot obtained from the equilibrium values of $\Gamma$ as a function of the amount of VAC at two calcium concentrations. From these plots a $\mathrm{K}_{\mathrm{d}}$ is calculated of $6 \times 10^{-9} \mathrm{M}$ with a $\Gamma_{\max }=0.25 \mu \mathrm{g} \mathrm{VAC} / \mathrm{cm}^{2}$ and $\Gamma_{\max }=0.07 \mu \mathrm{g} \mathrm{VAC} / \mathrm{cm}^{2}$ for $2 \mathrm{mM} \mathrm{Ca}{ }^{2+}$ and $0.5 \mathrm{mM} \mathrm{Ca} 2+$, respectively. The binding curves are monophasic as revealed after stepwise addition of VAC.

Binding of VAC is more then 95 reversible as followed from the addition of excess EDTA. No detectable adsorption is observed in the absence of calcium nor on pure DOPC.

There appears to excist a calcium dependence of the binding of VAC to negatively charged phospholipids. Fig. 3 shows the effect of varying calcium concentrations on the binding of WAC to a phospholipid bilayer, consisting of $20 \%$ Dops and $80 \%$ DOPC. Excess VAC (ten times the $K_{d}$ ) was present in these experiments. Equilibrium values of $r$ are shown in this figure as reached after stepwise addition of $\mathrm{CaCl}_{2}$. The half saturation ca2t-concentration on 20 DOPS/808 DOPC is $0.8 \mathrm{mM}$.

since prothrombin and factor $x_{a}$ bind to negatively charged large 


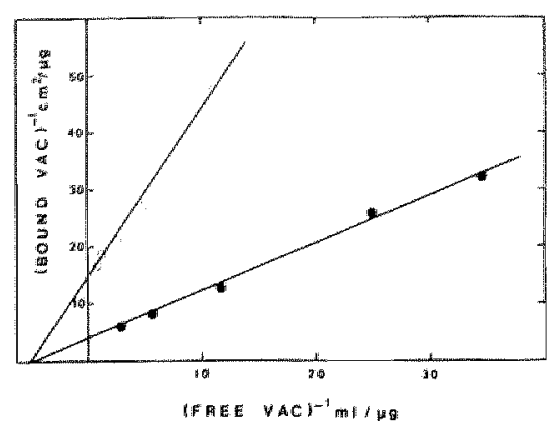

Fig. 2 Double-reciprocal plots of adsorbed mass of VAC to a bilayer of $20 \%$ DOPS/80\% DOPC as a function of the free VAC concentration.

Binding of VAC to a bilayer of 208 DOPS $/ 80$ o DOPC, stacked on a silicon slide, was estimated with an automated ellipsometer. Equilibrium values of adsorbed VAC are plotted reciprocal against the reciprocal values of the free VAC concentrations. Binding was studied at $0.5 \mathrm{mM}$ (O) and $2.0 \mathrm{~mm}$ calcium ( $\bullet$ ).

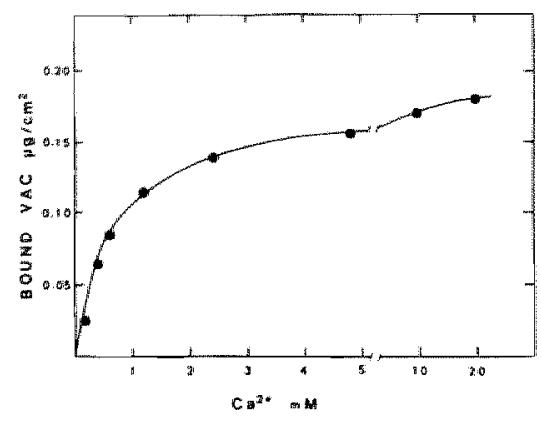

Fig. 3. Effect of the calcium concentration on the amount of $\mathrm{VAC}$, adsorbed to a 208 DOPS/BOz DOPC bilayer.

The calcium dependent binding of VAC to a bllayer of $20 \%$ DOPS/BO DOPC was measured with an automated ellipsometer. Equilibrium values are given as reached after stepwise addition of calcium. The VAC concentration was $2 \mu \mathrm{g} / \mathrm{ml}$.

volume phospholipid vesicles, both with a $\mathrm{K}_{\mathrm{d}}$ of about $2 \times 10^{-7} \mathrm{M}$ (24), we have examined the effect of VAC on the phospholipid binding of prothrombin and factor $x_{a}$ to large volume vesicles, composed of 208 DOPS/80\% DOPC. Fig. 4 shows that VAC inhibits dose-dependently the binding of prothrombin and factor $x_{\mathrm{a}}$ to these vesicles. At $20 \mu \mathrm{M}$ phospholipids, the binding of $100 \mathrm{nM}$ prothrombin and $10 \mathrm{nM}$ factor $x_{a}$ is reduced with $50 \%$ at $20 \mathrm{nM} \mathrm{VAC}$ and $60 \mathrm{nM}$ VAC, respectively.

The effect of VAC on the factor xa-catalyzed activation of prothrombin - VAC prolongs the clotting time in the MPT-test in a dose-dependent manner when coagulation is initiated with bovine thromboplastin (fig* 5). 


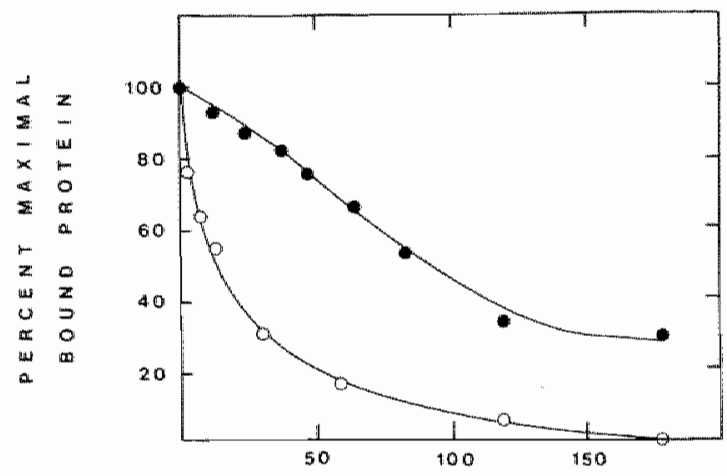

WA $\mathrm{A}$ (I)
Fig. 4. Effect of VAC on the binding of prothrombin and factor $X a$ to large volume phospholipid vesicles. Mixtures of $20 \mu M$ large volume vesicles (20\& DoPS/ $80 \%$ DOPCl, 100 nM prothrombin $(O)$ or 10 nM factor $\mathrm{x}_{\mathrm{a}}(\bullet), 3 \mathrm{mM} \mathrm{CaCl} 2$ and varying amounts of VAC were incubated for 5 minutes at $37^{\circ} \mathrm{C}$. After centrifugation of the mixtures, the resulting supernatants were assayed for prothrombin and factor $x_{a}$ concentration as described in materials and methods. From these values the amounts of bound prothrombin and factor $\mathrm{x}_{\mathrm{a}}$ were calculated, as percentage of maximal bound prothrombin and factor $x_{a}$ r respectively.

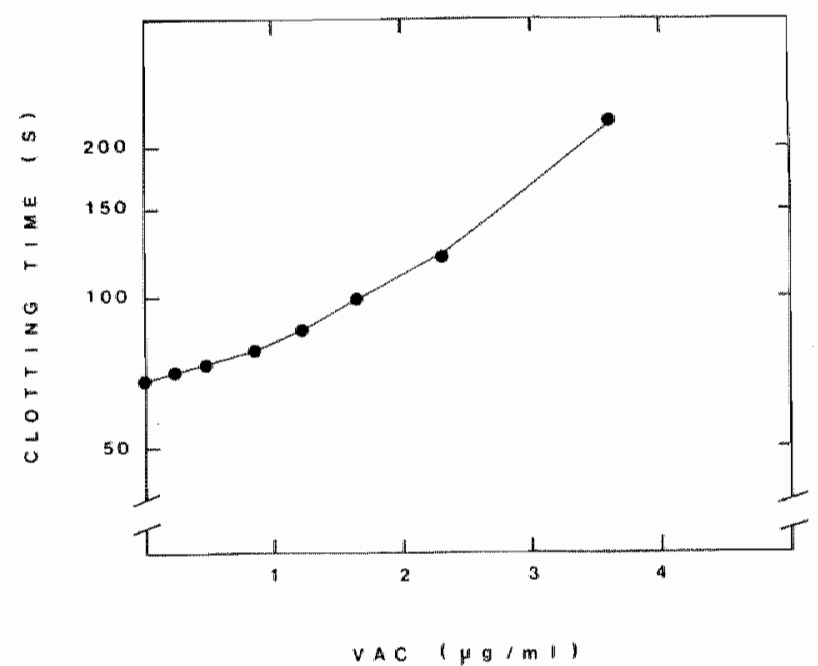

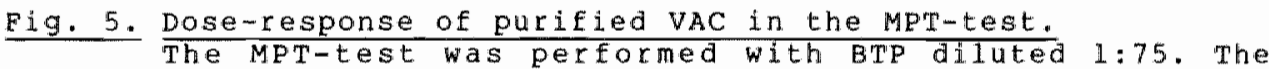
blank clotting time in the absence of VAC was 65 seconds. 


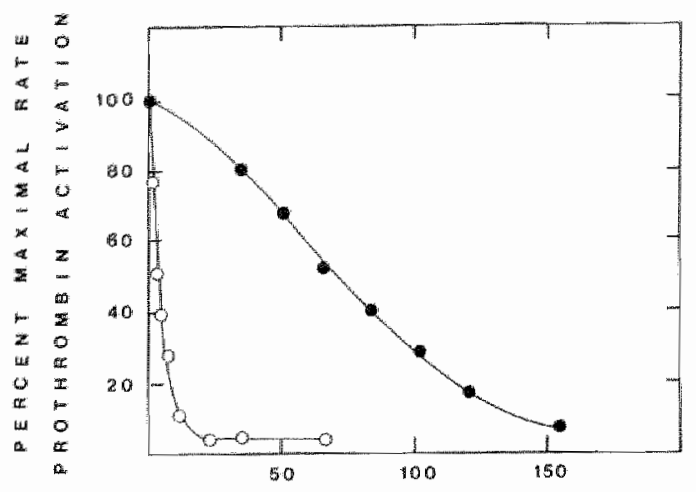

$v \in \mathrm{C}$ a

\begin{abstract}
Fig. 5. Effect of various of prothrombin activation. 10 nM Eactor $X_{a \text { a }} 0.5$ h M (O) or $5 \mu M 20{ }^{\circ}$ DOPS/80: DOPC vesicles $\bullet, 10 \mathrm{~mm}$ $\mathrm{CaCl}_{2}$, and various amounts of VAC, were stirred in TBSA at $37^{\circ} \mathrm{C}$ for 3 minutes. prothrombin activation was started with the addition of 1 M prothrombin. The rate of prothrombin activation was determined at different VAC concentrations and is expressed as percentage of the rate of prothrombin activation in the absence of VAC. The latter rates were $3.3 \mathrm{nM} I I a / m i n$ (0.5 "M phospholipid), and 10.9 nM IIa/min $(5 \mu \mathrm{M}$ phospholipid).
\end{abstract}

Since VAC inhibits factor $x_{a}$-induced clatting, but not thrombininduced clotting of plasma, and since the amidolytic activities of Eactor $x_{a}$ as well as of thrombin are not affected by vac, it is very unlikely that VAC should be an inhibitor directed against the active sites of these proteins.

In order to gain furthez insight in the mechanism through which VAC inbibits coagulation, we have explored the effects of VAC on the factor $x_{a}-c a t a l y z e d$ activation of prothrombin in a purified systen. In the absence of phospholipids, VAC, up to 5 " M, does not inhibit the activation of 1 M prothrombin by 10 aM factor $x_{a}$. Hence, VAC does not interfece with the catalytic activity of factor $x_{a}$ on prothrombin per se. If activation of 1 MM prothrombin by $10 \mathrm{nM}$ factor xa proceeds in the presence of phospholipids, a strong VAc-induced Inhibition is observed (fig. 6). In the presence of $0.5 \mu M$ and $5 \mu M$ phospholipids, a 508 inhibition of the activation is accomplished with 3 nM and 65 nM VAC, respectively. Examination of the time courses of prothrombin activation by factor $x_{a}$ in the presence of phospholipids, revealed that the VAC-induced inhibition, takes place immediately following the addition of VAC to the prothrombin activating complex, and is 
Fig. 7. Effect of the moment of addition of VAC to the prothrombinase, on prothrombin activation.

10 nM factor $X_{a}, 20$ m large volume phospholipid vesicles $/ 20$ DOPS/80\% DopCl, and $3 \mathrm{mM} \mathrm{CaCl} 2$ were stirred in TBSA for $3 \mathrm{minu-}$ tes. Prothrombin activation was started with the addition of $100 \mathrm{nM}$ prothrombin. At the indicated $t$ ime points samples were withdrawn, and tested for the amount of activated prothrombin ( ). 65 nM VAC was added to the reaction

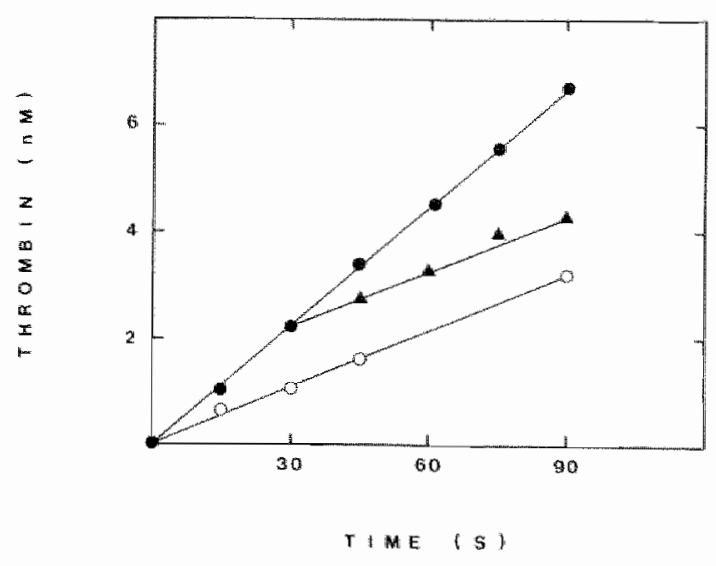
mixture either $15 \mathrm{~s}$ before ( O), or $30 \mathrm{~s}$ ( $\Delta$ ) after the activation was started.

linear in time (fig. 7). This linearity excludes a time-dependent action of VAC, like a proteolytic and a phospholipase activity. Further characterization of the type of inhibition was assessed by a kinetic approach. The activation of prothrombin by $10 \mathrm{nM}$ factor $x_{a}$ and $20 \mu$ phospholipids, was measured at varying prothrombin and VAC concentrations. The activation data are converted into Lineweaver-Burke plots (fig. 8). VAC appears to be a mixed-type inhibitor, which increases the $\mathbb{K}_{\mathrm{m}}$ and decreases the $V_{\text {max }}$ of the reaction. In addition to the other findings, these results strongly indicate an interference of VAC with the prothrombin activation through an interaction with the phospholipid surface.

\section{DISCUSSION}

Recently we reported the discovery of a novel anticoagulant protein in human umbilical cord arteries (15). This anticoagulant was shown to inhiblt factor $x_{a}$-catalyzed activation of prothrombin only, when the reaction proceeds in the presence of negati- 


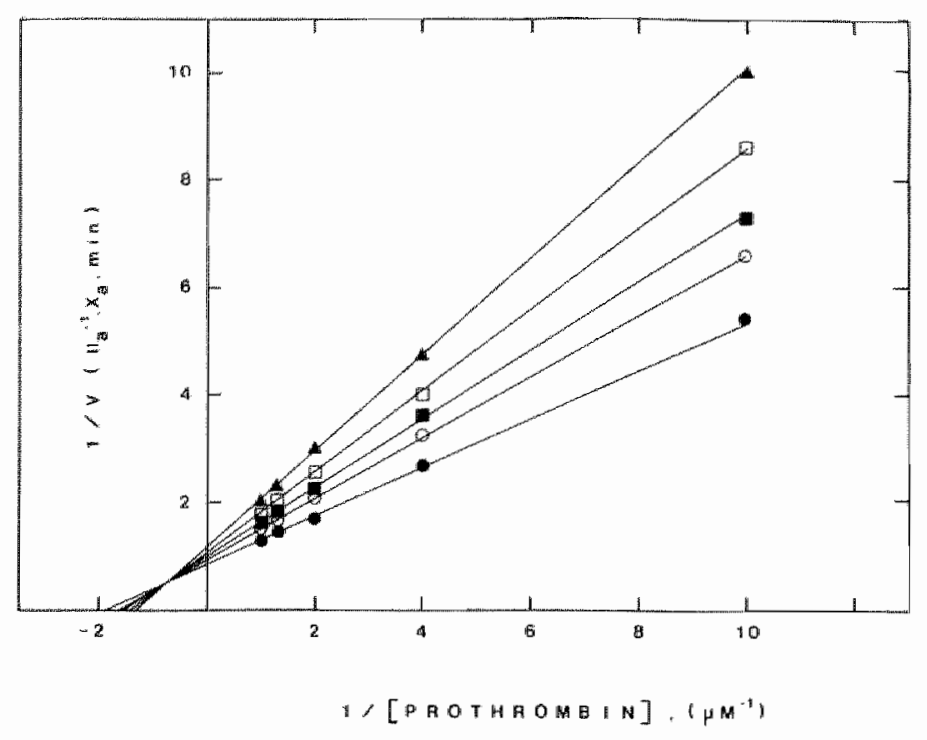

fig 8. Double-reciprocal plots of the rates of prothrombin activation as a function of the prothrombin concenEration. Effect of the VAC concentration.

$10 \mathrm{nM}$ factor $\mathrm{x}_{\mathrm{a}}, 20 \mu \mathrm{M} 20 \mathrm{o}$ DoPS/808 DOPC, $3 \mathrm{mM} \mathrm{CaCl} 2$, and varying amounts of VAC were stirced in TBSA for 3 minutes. Prothrombin activation was started by the addition of prothrombin. The rate of the prothrombin activation was determined as described in the materials and methods. VAC concentrations were, $0(\bullet), 5 \mathrm{nM}$ (O), $10 \mathrm{nM}(\mathbf{)}), 25 \mathrm{nM}(\mathrm{a})$, and $50 \mathrm{nM}(\boldsymbol{\Delta})$.

vely charged phospholipias. We then already suggested that the mechanism through which this protein inhibits coagulation, difEers fundamentally from those of the well known anticoagulants (8-12), and enclaves negatively charged phospholipids as a key part.

In this paper we have demonstrated the presence of an anticoagulant protein(s) in bovine aortic intima. From the chemical as well as the biochemical features, described for the anticoagulants in this paper and in (15), it is concluded that bovine VAC is very similar to the human umbilical cord anticaagulant. Therefore, we will adaress these anticoagulants with bovine vac 
and human VAC, from hereon. We also presented here a purlfication procedure for bovine VAC, as well as experiments, which elucidate the mechanism through which VAC inhibits the factor $x_{a}$-catalyzed conversion of prothrombin.

our purification data suggest that bovine wac is only a minor component of the aortic intima. I g of intima contains a minimum of $2.5 \mu \mathrm{g}$ of VAC. The exact concentration could not be determined because of a possible loss of material in the first purification steps. Upon analysis with gel electrophoresis, it appears that the purified bovine VAC contains two single chain proteins with $M_{r}=32,000$, and $M_{r}=34,000$. These proteins are no glycoproteins and have identical pI-values of about 4.5, indicating that they are acidic at physiological pH. Furthermore, with a very sensitive method, we could exclude the presence of GLA-residues in bovine VAC. The importance of this observation is discussed below.

The association of the anticoagulant activity with these two proteins has been confirmed by elution experiments. At the moment, however, it remains unknown whether the anticoagulant activity is associated with either one of these proteins or with both. Due to their similarities in chemical properties, we failed, as yet, to separate these proteins from each other.

Experiments with negatively charged, large-volume phospholipid vesicles demonstrated that both proteins bind to these vesicles in the presence of calcium only. With the use of an automated ellipsometer (26) this observation was confirmed, and, moreover, the binding data could be quantified. Binding of bovine vac to a phospholipid surface requires the presence of both calcium and negatively charged phospholipids. Unlike the vitamin K-dependent coagulation factors, the calcium-dependent binding of which to negatively charged phospholipids is explained by the presence of GLA-residues (33-35), bovine VAC lacks these structures. Hence, bovine VAC is a phospholipid binding protein, the binding of which depends on the presence of calcium, although GLA-residues are absent. The mechanism of this caloium-dependent binding remains to be resolved.

The monophasic behavior observed for the binding of bovine VAC to 
206 DOPS/B0 DORC surface, indicates that both proteins $M M_{K}=\$ 2,000$, and $\left.M_{K}=34,000\right)$ show similar binding kinetics. Moreover, this surface contains a single class of binding sites for bovine vac with a Ka of $6 \times 10^{-9} \mathrm{M}$. Binding parameters as meadured with the ellipsometer (26) are comparable with those obtained with the employment of other methods $(24,31,32)$. Thus, extrapolation of the determined binding parameters of bovine VAC to the large volume vesicle system (24), indicates that bovine VAC has about a 30 times higher affinity for a 208 DoPS/808 DOPC surface as compared to prothrombin and factor $x_{a}(24)$. In concert to this, it is observed that VAC interferes with the binding of prothrombin and factor $x_{\text {a }}$ to such a phospholipid surface.

Bovine VAC strongly inhibits the factor $x_{a}$-catalyzed conversion of prothrombin in the presence of phospholipids. It is now well established that prothrombin activation in the presence of phospholipids is a surface bound process $(7,36-38)$, in which, in the absence of factor $v_{a}$, phospholipid-bound prothrombin is converted by phospholipid-bound factor $x_{a}$. Our data indicate that VAC interferes with both prothrombin and factor $x_{a}$ binding on the phospholipid surface, and thereby interferes with the membranebound process of prothrombin activation. The type of inhibition is not purely competitive but appears to be a mixed-type. Bovine VAC not only increases the $k_{m}$ of the prothrombin activation but it decreases the $v_{m a x}$ of this reaction, as well. The increase of the $K_{m}$ is readily explained from the interference of bovine vAC with prothtombin binding to the phospholipids. Whereas the decreased $V_{m a x}$ likely originates from a interference with factor $x_{a}$ binding to the phospholipids. A similar type of inhibition of the prothrombinase complex has been described for fragment 1 and fragment 1.2 (39), which are GLA-containing activation peptides of prothrombin.

In conclusion we can state that we have discovered a protein(s) (VAC), present in human and bovine arterial tissues, that can be classified to the extrinsic membrane proteins. Through its nonenzymatically interaction with megatively charged phospholi- 
prothrombin, and probably also other phospholipid dependent procoagulant reactions. On basis of this mechanism of anticoagulation, VAC can be assigned to the group of anticoagulants, which interfere with the accessory components of procoagulant complexes. To this class already belong activated protein $C(11,12)$, some phospholipases $A_{2}$ (13), and some Lupus anticoagualant species (14). Among them $V A C$ is unique in these respects, that VAC binds calcium-dependently and reversibly to negatively charged phospholipids, and anticoagulates without proteolytic action.

Whether VAC has a physiological function as an anticoagulant is unknown, as yet. Its location in the intima of a vessel wall, however, may indicate a role for VAC as an anitcoagulant after vessel wall injury, when negatively charged phospholipid structures become exposed to plasma constituents.

\section{ACKNOWLEDGEMENTS}

The authors wish to thank J. Govers-Riemslag and T. Janssen for kindley providing the purified bovine clotting factors, B. Soute, who performed the GLA-determinations, and P. Roszek for typing this manuscript.

\section{LITERATURE}

1. Macfarlane, R.G. (1964) Nature (London) 202, 498-499

2. Davie, E.W., and Ratnoff, O.D. (1964) Scilence 145, 1310-1312

3. Jackson, C.M., and Nemerson, Y. (1980) Ann. Rev. Biochem. $49,765-811$

4. Tans, G., and Rosing, J. Blood coagulation, New Comprehensive Biochemistry, Elsevier, Amsterdam vol. 13, 59-85

5. Suttie, J.W., and Jackson, C.M. (1977) Physiol. Rev. 57, $1-70$

6. Nesheim, M.E., Taswel1, J.B., and Mann, K.G. (1979) J. Biol. Chern. 254, 10952-10962 
7. Rosing, J., Tans, G., Gover-Riemslag, J.W.P., wal, R.F.A., and Hemker, H.C. (1980) J. Blol. Chem. 255, 274-283

8. Downing, M.R., Bloom, J.W., and Mann, K.G. (1978) Biochemistry $17,2649-2653$

9. E111:, V., Scully, M., Macgregor, I., and Kakkar, V. (1982) Blochim. Biophys. Acta 701, 24-31

10. Travis, J., and Salvesen, G.S. (1983) Ann. Rev. Biochem. $52,655-709$

11. Walker, F.J., Sextan, P.N., and Esmon, C.T. (1979)

Biochim. Biophys. Acta 571, 333-342

12. Vehar, G.A., and Davie, E.W. (1980) Biachemistry 19,410-416

13. Boffa, M.C., Verheij, H.M., and de Haas, G.H. (1982) Thromb. Haemostas. 47,299

14. Thiagarajan, P., Shapiro, S.S., and De Marco, L. (1980) J. Cin. Invest. 66, 397-405

15. Reutelingsperger, C.P.M., Hornstra, G., and Henker, H.C. (1985) Eur. J. Biochem. 151, 625-629

16. Reutelingsperger, C.P.M., Hornstra, G., and Hemker, H.C. (1985) Thromb. Haemostas. 54, abstract 0303

17. Stenflo, J. (1976) J. Biol. Chem. 251, 355-363

18. Fujikawa, K., Legaz, M.E., and Davie, E.W. (1972) Biachemistry $11,4882-4891$

19. Fujikawa, K., Legaz, M.E., and Davie, E.W. (1972) Biochemistry 11, 4892-4899

20. Fujikawa, K., Thopmson, A.R., Legaz, M.E., Meyer, R.G., and Davie, E.W. (1973) Biochemistry 12, 4938-4945

21. Owen, W.G., Esmon, C.T., and Jackson, C.M. (1974) J. Biol. Chem.249,594-605

22. Van Dam-Mieras, M.C.E., Muller, A.D., van Dieijen, G., Hemker, H.C. (1984). Blood coagulation enzymes, Methods of Enzymatic Analysis, Verlag Chemie GmbH, Weinheim. (Bergmeyer, H. U. ed.). Vol 5: pp. 365-394

23. Lowry, O.H., Rosebrough, N.V., Farr, A.L., and Randall, R.J. (1951) J. Biol. Chem. 193, 265

24. Van de Wart, P., Bruls, H., Hemker, H.C., and Lindhout, T. (1983) Biochemistry 22, 2427-2432 
25. BSttcher, C.J.E., van Gent, C.M., and Pries, C. (1961) Anal. Chim. Acta 24203-207

26. Kop, J.M.M., Cuypers, P.A., Linahout, T., Hemker, H.C., ana Hermens, W. Th. (1984) J. Biol. Chem. 259, 13993-13998

27. Van Dieijen, G., Tans, G., Rosing, J., and Hemker, H.C. (1981) J. Biol. Chem. 255, 274-283

28. Laemil, U.K. (1970) Nature (London) 227, 680-685

29. Segrest, J.P., and Jackson, G.L. (1972) Methods in Enzymology vol. $28,54-63$

30. Kuwada, M., and Katayama, K. (1983) Anal. Biochem. I31, $173-178$

31. Nelsestuen, G.L., and Broderius, M. (1977) Biochemistry $16,4172-4177$

32. Mayer, L.D., Nelsestuen, G.L., and Broekman, H.L. (1983) Biochemistry 22, 316-321

33. Stenflo, J., and Suttie, J.W. (1977) Ann. Rev. Biochem. 46, $157-172$

34. Melsestuen, G.L., Kisiel, W., and Discipio, R.G. (1978) Biochemistry 17, 2134-2138

35. Dombrose, F.A., Gitel, S.N., Zawalich, K., and Jackson, C.M. (1979) J. Biol. Chem. 254,5027-5040

36. Nelsestuen, G.L. (1978) Fed. Proc. 37, 2621-2625

37. Van Rijn, J.L.M.L., Govers-Riemslag, J.W.P., Zwaal, R.F.A., and Rosing, J. (1984) Biochemistry 23, 4557-4564

38. Nesheim, M.E., Elid, S., and Mann, K.G. (1981) J. Biol. Chem, $256,9874-9882$

39. Govers-Riemslag, J.W.P., speyer, H., Zwal, R.F.A., and Rosing J. (1985) Thromb. Res. $38,375-388$ 

CHAPTER 4

\author{
RAPID PURIFICATION AND FURTHER CHARACTERIZATION \\ OF THE VASCULAR ANTICOAGULANT (VAC).
}

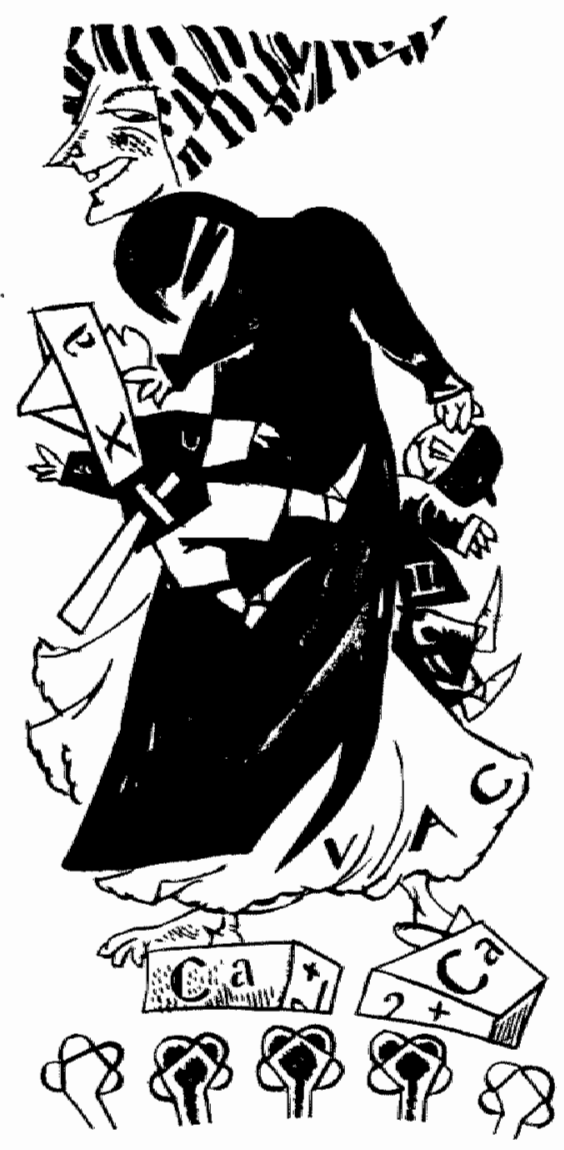



RAPID PURIFICATION AND EURTHER CHARACTERIZATION OF THE VASCULAR ANTICOAGULANT (VAC).

Reutelingsperger, C.P.M., Maroofi, K., Kop, J.M.M., Hornstra, G., and Hemker, H.C.

SUMMARY

Vascular anticoagulant (VAC), a single chain anticoagulant protein finct discovered in human umbilical cord arteries, is present in human placenta. A rapid and convenient purification procedure of placenta-VAC (P-VAC) is presented. The molecular weight and the amino acid composition of P-VAC appear to be identical with those of umbilical cord VAC (U-VAC). Both proteins affect in a similar way the factor $x_{a}$-catalyzed prothrombin activation. It is, moreover, shown that p-vac inhibits the phospholipid dependent factor $x$-activation.

P-VAC binds with a $\mathrm{Ka}=7.8 \times 10^{-9}$ M to a phospholipid bilayer, consisting of $20 \%$ dioleoyl phosphatidylserine and $80 \%$ dioleoyl phospatidylcholine in a calcium-dependent way. The phospholipid to VAC ratio at saturation was $n=44$ and $n=29$ moles $/$ mol for $0.5 \mathrm{mM}$ $\mathrm{Ca}^{+2}$ and $2 \mathrm{mM} \mathrm{Ca}+2$, respectively. Half maximal binding occurred at $0.4 \mathrm{mM} \mathrm{Ca}+2$.

$P-V A C$ has a quenched intrinsic fluorescence signal, which is not affected neither by calcium nor by EDTA. With the use of serine proteases further evidence was obtained that calcium and EDTA do not induce a conformational transition of P-VAC.

In addition, the effects of the proteolytic enzymes on VAC demonstrate that it has a stabilized tertiary structure, with mainly glutamic acid and/or aspartic acid residues at the exterior side of the molecule.

The mechanism of the calcium dependent VAC binding to phospholipud is discussed. 
INTRODUCT ION

The calcium dependent binding of the vitamin $k$-dependent coagulation factors to negatively charged phospholipids is essential. for blood clotting $(1-3)$. Interference with this binding in one way or another will impair the process of blood coagulation, as is demonstrated by the following compounds.

1) Vitamin K-antagonists inter fere with the posttranslational formation of $\gamma$-carboxyglutamic acid (GLA), which are essential for proper phospholipid binding. K-related coagulation factors, lacking GLA-residues are poor substrates in the coagulation process $(4-6)$.

2) GLA-containing activation peptides of prothrombin (7) and factor $X$ (8) have been reported to possess anticoagulant activity, due to their calcium dependent affinity for phospholipids.

3) Antibodies, directed against acidic phospholipids inhibit the phospholipid dependent procoagulant reactions (9).

some basic phospholipases $\mathbb{A}_{2}$ exhibit an anticoagulant activity $(10,11)$, because of their binding to phsopholipids, which are subsequently hydrolyzed by these phospholipases.

In a previous paper we reported the existence of a vascular protein (VAC), which inhibit the factor $x_{a}$-catalyzed activation of prothrombin, only when phospholipids are present 112 , chapter 2 of this thesisl.

VAC can be isolated from human umbilical cord arteries, and bovine aortic intima (chapter 3 of this thesis). We have established that VAC, a non GLA-protein with no phospholipase activity, binds in calcium dependent way to negatively charged phospholipids, and thereby it interferes with the assembly of prothrombinase on this surface. In this paper we show that VAC is also present in human placenta. We present a rapid and convenient purification procedure for VAC, as well as a further characterization of this vascular anticoagulant. 
MATERIALS AMD METHODS

Materials - The Fast Protein Liquid Chromatography - system (ERLC) was obtained from Pharmacia (Uppsala, sweden). Polybuffer 74. DEAE-Sephacel, the Superose 12, Mono 2 , and Mono $p$ columns were also purchased from Pharmacia. The phastgel electrophoresis system as well as the ready prepared polyacrylamide phastcels were products of Pharmacia. The chromogenic substrate 52337 was purchased from AB Kabi Diagnostica (stockholm, Sweden). Trypsin (EC 3.4.21.4) and chymotrypsin (EC 3.4.21.1) were obtained from Sigma. Elastase (EC 3.4.21.36) and subtilisin ( $\mathrm{EC} 3.4 .21 .14)$ were products of Boehringer Mannheim.

Proteins - Umbilical cord VAC (U-WAC) was purified from human umbilical cord arteries with the purification method described in (chapter 3 of this thesis). Placenta VAC (P-VAC) was isolated from human placenta, which was obtained immediately after delivery. The placenta was cooled at $4^{\circ} \mathrm{C}$ and rinsed free of adhered blood. Membraneous material was removed prior to homogenization of the placenta in Tris buffered saline (TBS, $50 \mathrm{mM}$ Tris/HCl, $100 \mathrm{mM} \mathrm{NaCl,} \mathrm{pH} 7.4)$, containing $1 \mathrm{mM}$ EDTA, $1.6 \mathrm{~g} / 1$ benzamidine and $1.57 \mathrm{mg} / 1$ soybean trypsin inhibitor. The $20 \%$ homogenate (w/v) was fractionated by the ammonium sulfate precipitation as described in (chapter 3 of this thesis). The VAC-containing fractions were further purified by batchwise asorption to DEAE-Sephacel at $50 \mathrm{mM} \mathrm{NaCl,} \mathrm{pH} \mathrm{7.4.} \mathrm{The} \mathrm{bound} \mathrm{VAC}$ was released with a one step elution with $300 \mathrm{mM} \mathrm{NaCl}$ at pH 7.4 . column chromatography was subsequently performed at ambient temperature and increased pressure, using a ELC-system. Gel filtration of the VAC-containing fractions was performed with a superose 12 column, equilibrated with $20 \mathrm{~mm}$ bis-Tris/HC1, $100 \mathrm{~mm}$ NaCl, $\mathrm{pH}$ 6.3. Subsequently, the eluted WAC was submitted to lon exchange chromatography on Mono $Q$, equilibrated with the latter buffer. A linear gradient of $\mathrm{Nacl}$ in $20 \mathrm{mM}$ bis-Teis/HCl, $\mathrm{pH} 6.3$, was used to release vac from the column. Finally, the vaccontaining fractions were rechromatographed on superose 12. The 
purified P-VAC was dialyzed against TBS, and stored at $-700^{\circ} \mathrm{C}$. During the purification procedure the fractions were evaluated for VAc-activty, protein concentration, and protein composition, with the MPT-test $(12$, chapter 2 of this thesis), the sedmak procedure (13) and gel electrophoresis, respectively.

Bovine factors $x_{2}$, IX and thrombin were prepared as described by van Dieijen et al. (14). Factor VIIIC was purified from bovine blood according to the method of Vehar d Davie (15) as modified by Van Dieijen et al. (16). Factor VIIIa was prepared by activation of factor VIIIC (1.75 $\mathrm{nM})$ with thrombin (4 $\mathrm{nM})$ for $1 \mathrm{~min}$. at $37{ }^{\circ} \mathrm{C}$ (16). Concentrations of factors IXa, and thrombin were determined by active-site titration with P-NGB-p-nitrophenyl-p"guanidinobenzoate as described elsewhere $(17,18)$. Factors WII and $x$ were quantified according to the methods of $(15,16)$.

Assay of VAC-activity - The MPT-test, which is described in detail elsewhere (12, chapter 2 of this thesis), was used throughout the purification procedure in order to test for VAC-activity. Expression of this activity in arbitrarily defined units was also performed with the MPT-test, as described previously (chapter 3 of this thesis).

Electrophoresis - Polyacrylamide gel electrophoresis in the presence and absence of SDS was performed with ready prepared phastgel gradient 10-15 gels in combination with Phastgel SDS and Native buffer strips. Staining with Coomassie Briliant Blue and destaining of the gels were carried following the recommendations of the manufacturer.

Amino acid analysis - U-VAC and P-VAC, dialyzed against distilled water, were hydrolyzed under vacuum in $6 \mathrm{~N} H C l$, 018 phenol, at $110^{\circ} \mathrm{C}$ for 18,48 and 72 hours. The hydrolysates were evaluated with a $L K B$. 4400 amino acid analyser, operating with iithium buffers. The recovery of amino acids were plotted against the different times of hydrolysis. The extrapolated maximum recovery was estimated from these plots. 
Intrinsic fluorescence - Fluorescence measurements were made with the SPF-500 spectrofluorometer of SLM-Aminco. Emission band pass was $2 \mathrm{~nm}$ and excitation band pass was $4 \mathrm{~nm}$. Slits were closed in between the scans to avoid photodegradation. Temperature in the cell was maintained at $25^{\circ} \mathrm{C}$. Samples were excitated at $285 \mathrm{~nm}$. Emission intensity was monitored at 1 nm intervals from 300 to $400 \mathrm{~nm}$. Back ground signals due to solvents were substracted, and dilution due to the adition of titrant was corrected.

Phospholipid vesicle preparation and phospholipid bilayer preparation on silicon slides - Phospholipid vesicles composed of 258 DOPS and 758 DOPC were prepared as described by (17). Phospholipid bilayers were stacked on silicon slides in a preparative Langmuir trough (Landa type FW-1) as described in detail earlier (19).

P-VAC binding to a phospholipid bilayer - The binding of P-VAC to a phospholipid bilayer $(20 \%$ DOPS/80\% DOPC) was examined with an automated ellipsometer. Details of this technique and the mathematical equations for calculation of the equilibrium binding parameters are described elsewhere (19, chapter 3 of this thesis).

Intrinsic factor X-activation - The determination of the factor $I_{a}$ - catalyzed factor X-activation in the presence of factor VIIIa and phospholipid vesicles was performed as described in detail by $(20)$. The only difference being 1 s the use of bovine factor IXa instead of human factor IXa.

\section{RESULTS}

Purification of placenta VAC - Application to a human placenta of the first purification steps, established for U-VAC and bovine VAC (chapter 2 and 3 of this thesis), revealed the presence of VAC in this tissue. A purification method for P-VAC was developped, involving the FPLC-system. This method is fast and can be performed at ambient temperature. Gel filtration on a superose 12 


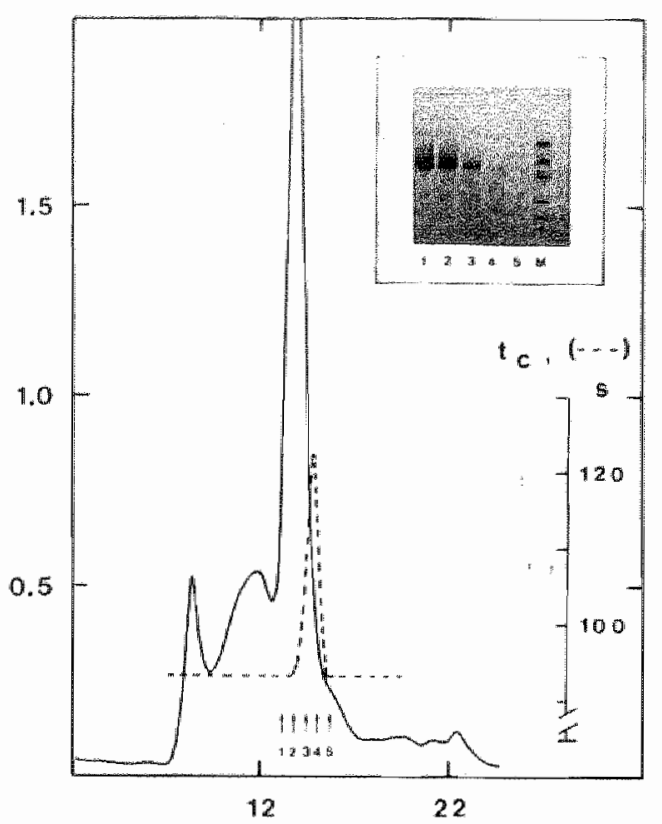

Fig. 1.Gel filtration on Superose 12 .

This purification step is the first one in the sequence, which employes the FPLC-system. The column was equilibrated ith $20 \mathrm{mM}$ bis-Tris/HCl, $100 \mathrm{mM} \mathrm{NaCl}(\mathrm{pH} 6.3)$. The effluent was monitored at $280 \mathrm{~nm}$ for protein contents. Samples were taken from the fractions and assayed in the MPT-test for VAC-activity. The inset shows a gel electrophoretic analysis of several fractions. The numbers of the lanes correspond with the numbers below the arrows, which in turn indicate the positions in the effluent of the analyzed samples. Lane $M$ represents the low molecular weight markers, which are from top to bottom; $94 \mathrm{k}, 67 \mathrm{k}, 43 \mathrm{k}, 30 \mathrm{k}, 20 \mathrm{k}$, and $14 \mathrm{k}$ Daltons.

VOLUME, mI

column was completed within one hour. P-VAC elutes from this colurn in the molecular weight range of 32 to $35 \mathrm{kDA}$ (fig. 1 ). The P-VAC fractions were pooled and subsequently applied to the anion exchanger Mono $Q$. P-VAC bound to this column at $100 \mathrm{mM}$ NaCl, pH 6.3. A linear gradient of Nacl was established to release VAC from the Mono Q. Elution of VAC occurred at $190 \mathrm{mM}$ NaCl (fig. 2).

The VAC-containing peak was reapplied to the superose 12, and appeared to consist of about $85 \%$ VAC and some contaminants with bigher molecular weights (fig. 3 ). 


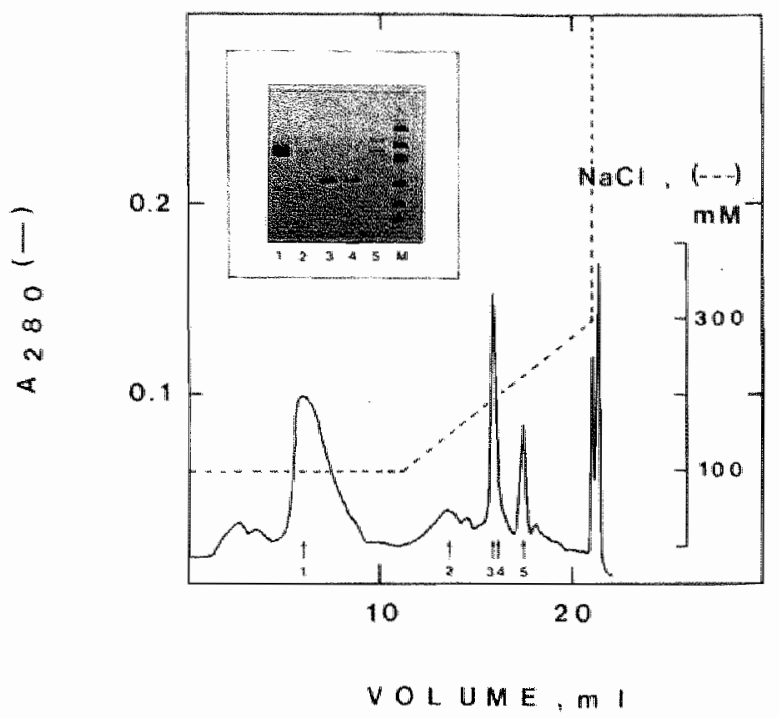

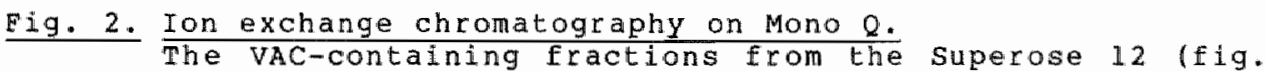
1) were applied to a Mono $Q$ column, equilibrated with the elution buffer of the superose 12. A linear gradient of NaCl was established for VAC-elution. The effluent was monitored at $280 \mathrm{~nm}$, and assayed for VAC-activity (not shown), which was only associated with the protein peak, indicated by the arrows 3 and 4.

The inset presents the gel electrophoresis of several samples of the effluent. The numbers of the lanes correspond with the numbers below the arrows. Lane $M$ give the markers (from top to bottom); $94 \mathrm{k}, 67 \mathrm{k}, 43 \mathrm{k}, 30 \mathrm{k}$, $20 \mathrm{k}$, and $14 \mathrm{k}$ Daltons.

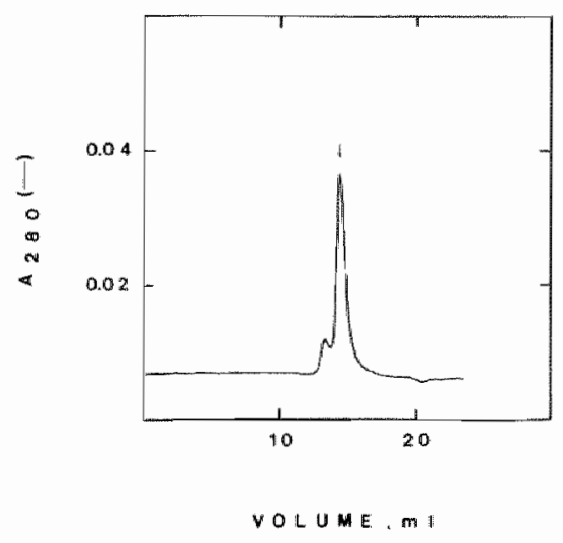

fig. 3. Gel filtration on superose 12; The final puriflcation step for P-VAC.

The protein peak, which eluted from the Mono $Q$ (fig. 2) and which contained the VAC, was reapplied to the superose column, equilibrated ith $20 \mathrm{mM}$ bis-Tris/ HCl, $190 \mathrm{mM} \mathrm{NaCl}(\mathrm{pH} 6.3)$. The effluent was monitored at $280 \mathrm{~nm}$ and assayed for VAC-activity (data not shown). Only the protein peak, indicated by the arrow, expressed VAC-activity. This peak was homogeneous for a 32 kDa protein, as judged with gel electrophoresis. 
Table 1

summary of the purification of P-VAC

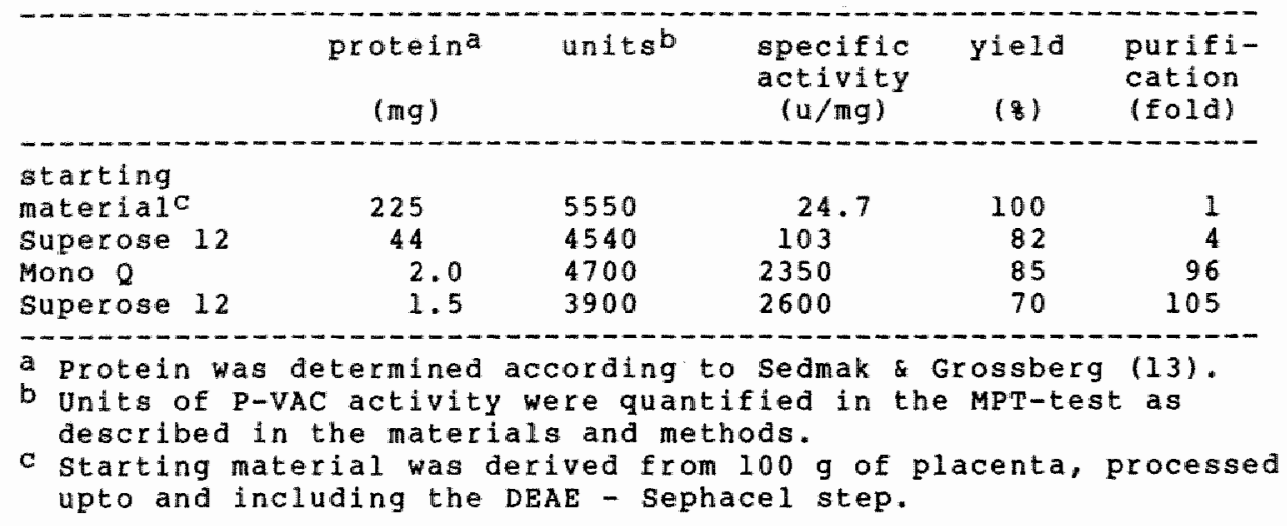

Table 2

Amino acid composition of P-VAC and U-VAC

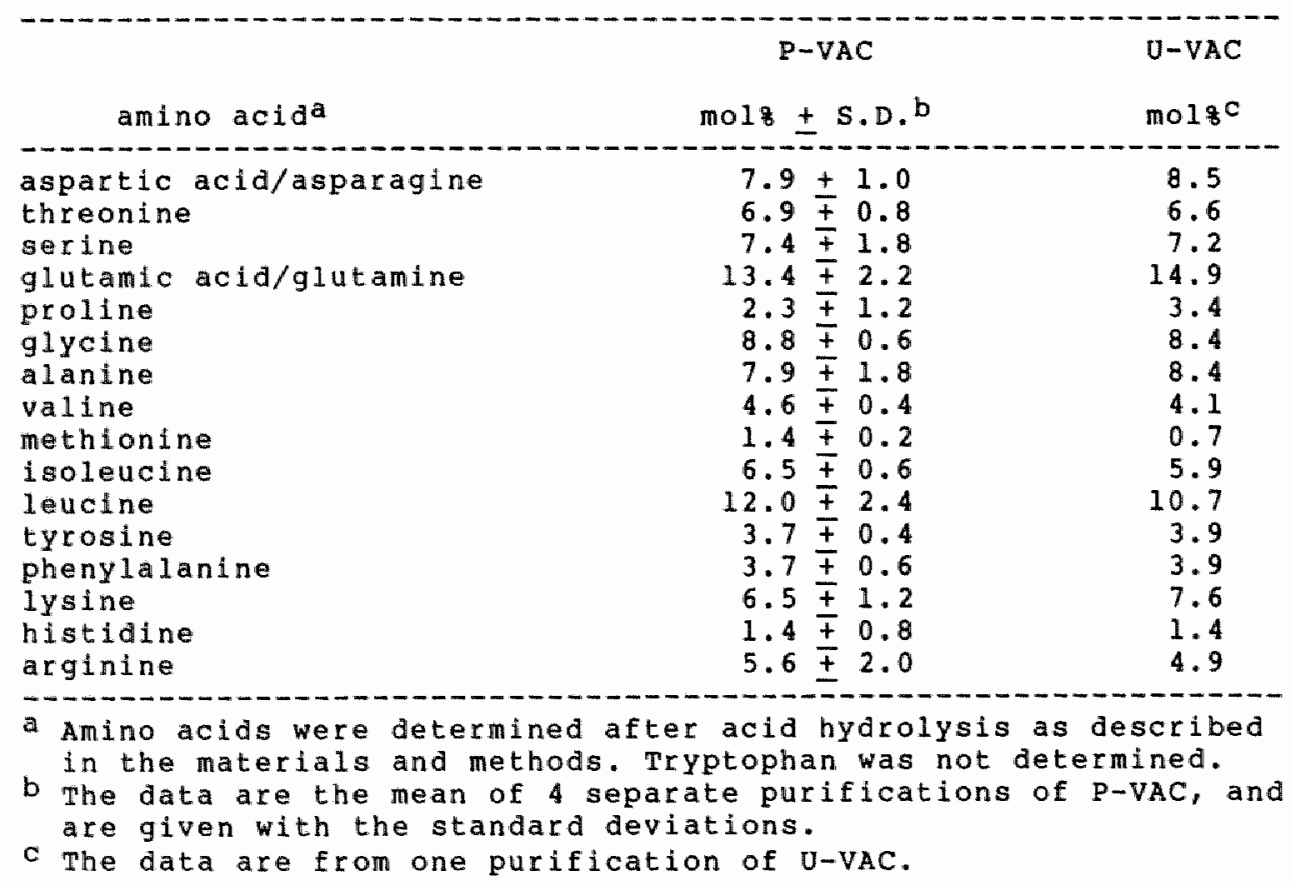


During the FPLC-procedure, VAC-activity was quantified and protein concentrations were determined. These results are summarized in table $1.100 \mathrm{~g}$ placenta contains about $1.5 \mathrm{mg}$ P-VAC, having a specific activity of about 2600 units/mg.

Comparison of P-VAC with U-VAC - Protein chemical characterization of P-VAC revealed that, like U-VAC, it is a single chain protein $(M r=32,000)$ with a non glycoprotein nature. Furthermore, the presence of GLA-residues in p-VAC could be excluded. The amino acid composition of P-VAC is comparable to that of $\mathrm{V}-\mathrm{VAC}$ (table 2), as was determined after acid hydrolysis. This procedure features a conversion of asparagine and glutamine into aspartic acid and glutamic acid, respectively. Furthermore, cysteine, cystine, and tryptophan residues cannot be recovered.

As to their anticoagulant activities both proteins are similar in all respects tested. The dose-responses of U-VAC and P-VAC in the MPT-test are identical. Moreover, prothrombinase activity is inhibited by P-VAC, only when the factor $x_{a}$-catalyzed activation of prothrombin takes place in the presence of negatively charged phospholipids. The amidolytic activities of factor $X_{a}$ and prothrombin are not affected by P-VAC. Exposure of $\mathbb{P}-V A C$ to $560^{\circ} \mathrm{C}$ renders the molecule inactive. Hence, the mechanism through which P-VAC inhibits coagulation, is likely to be similar to that of U-VAC.

Effect of P-VAC on the intrinsic factor x-activation - similar to U-VAC, P-VAC inhibits the phospholipid dependent activation of prothrombin. We have explared the effect of p-vac on another phospholipid dependent procoagulant reaction, the intrinsic factor $x$-activation. As expected, the activation of factor $x \quad b y$ factor IXa in the presence of phospholipids and factor VIII is inhibited by $\mathrm{P}-\mathrm{VAC}$ in a dose-dependent manner (fg. 4). Furthermore the extent of inhibition depends on the phospholipid concentration. At $2 \mu \mathrm{M}$ phospholipids, 17.5 nM VAC inhibits with 50 s the rate of factor $X(1 \mu M)$ activation by factor $I_{a}(0.2 \mathrm{nM})$ and factor VIIIa $(0.35 \mathrm{nM})$ by 50 . At $10 \mathrm{mM}$ phospholipids a $50 \%$ inhibition is accomplished with $125 \mathrm{nM}$ VAC. 
Eig. 4. Eefect of P-VAC on the intrinsic factor $x-$ activation.

0.2 nH factor Ixa, $0.35 \mathrm{nM}$ factor WII a, varying amounts of $\mathrm{E}-\mathrm{VAC}, 3 \mathrm{mM}$ $\mathrm{CaCl}_{2}$, and 2 H 25 DOPS/ 75 DOPC vesicles ( $O$ ) or $10 \mu$ of these vesicles

- ) were incubated at $37{ }^{\circ} \mathrm{C}$ in TBS, containing 0.5 mg/ml human serum albumine. The activation of factor $x$ was started with the addition of 1 M factor $X$. The rates of eactor $X$ activation were determuned as described in materials and methods and are expressed as percentage of the maximal rates, which were $1.8 \mathrm{nM} \mathrm{x}_{a} / \mathrm{min}$ ( ) and $1.1 \mathrm{nM} \mathrm{x}_{\mathrm{a}} / \mathrm{min}$ $(0)$.

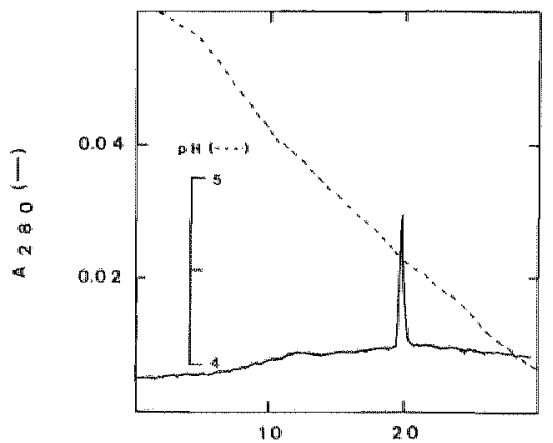

WOLUME, MI

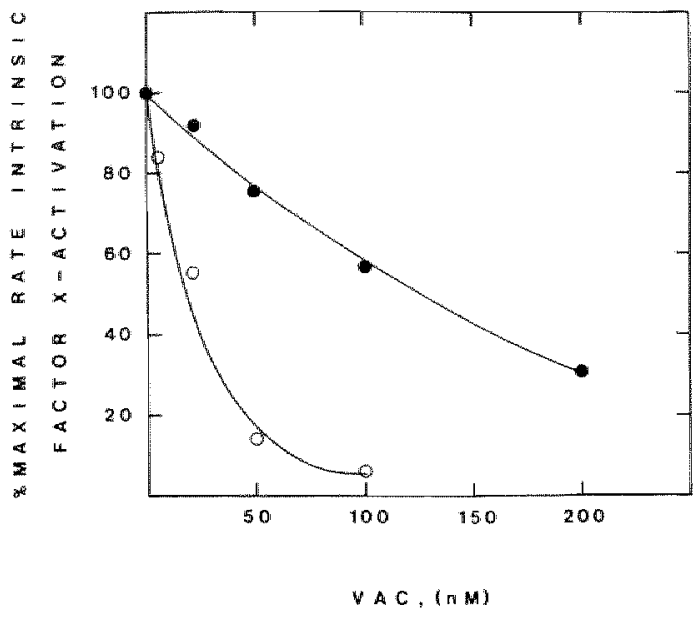

Fig. 5. Chromatofocussing of $P-V A C$ The Mono $\bar{P}$ column was preadjusted to $\mathrm{pH} 6.3$ with $20 \mathrm{mM}$ bis-Tris/ HCl ( $\mathrm{pH} 6.3) .25 \mu \mathrm{g}$ of purified $\mathrm{p}-\mathrm{VAC}$ was applied to the column, and subsequently eluted by developing a pH gradient, which was established by elution with Polybufeer 74 , adjusted to $\mathrm{pH} 6.3$. 


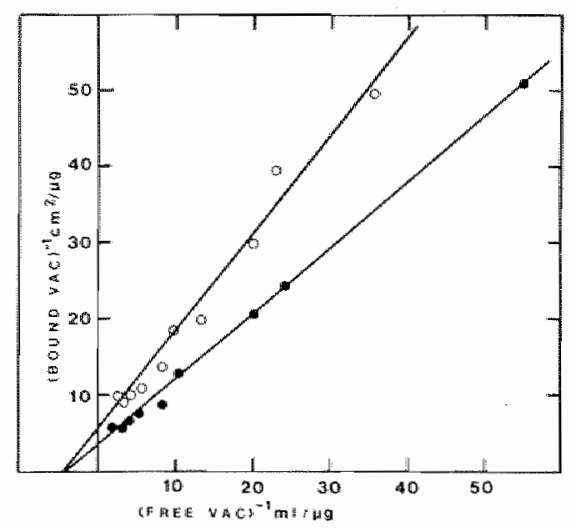

Fig. 6. Double reicprocal plots of adsorbed mass of P-VAC to a bilayer of $20 \%$ DOPS/808 DOPC as a function of the free P-VAC concentration.

Binding on a 208 DOPS/808 DOPC bilayer stacked on a silicon slide was measured in an automated elipsometer. $\mathrm{K}_{\mathrm{d}}$ and $\Gamma_{\max }$ were estimated from the double reciprocal plots at 0.5 $\mathrm{mM}(\mathrm{O})$ and $2.0 \mathrm{mM} \mathrm{CaCl} 2$ ( ) at $37^{\circ} \mathrm{C}$.

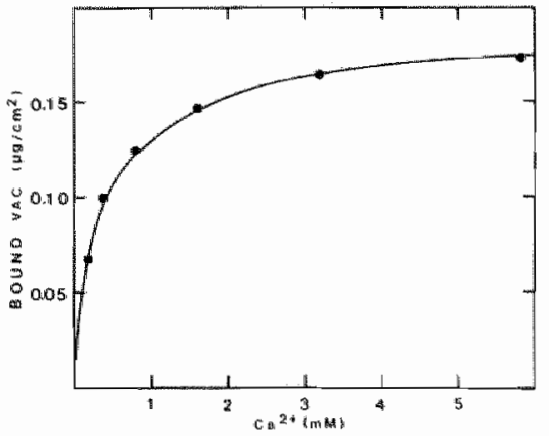

Fig. 7. Effect of the calcium concentration on the amount of P-VAC, adsorbed to a 20 s DOPS/80\% DOPC bilayex.

The calcium dependent binding of P-VAC to a bilayer of $20 \mathrm{~g}$ DOPS/ 80 o DOPC was measured on an automated elipsometer. Equilibrium values are given as reached after stepwise addition of $\mathrm{CaCl}_{2}$. The P-VAC concentration was $2 \mu \mathrm{g} / \mathrm{m} 1$.

Characterization of P-VAC - To investigate whether or not P-VAC excists in different formes with identical molecular weights, a sample of P-VAC was chromatofocussed on a Mono $P$ column, Erom which it eluted as a single sharp peak at pil 4.6 (fig. 5). P-VAC binding to a phospholipid billayer (20\% DOPS/80\% DOPC) was guantified with an automated ellipsometer. Fig. 6 shows a double reciprocal plot obtained from the equilibrium values (amount of deposited VAC in $\left.\mu \mathrm{g} / \mathrm{cm}^{2}\right)$ as a function of the amount of P-VAC at two calcium concentrations. From these plots a $k_{d}$ is calculated of $7.8 \times 10^{-9} \mathrm{M}$ with a $\Gamma_{\max }=0.18 \mu \mathrm{g} \mathrm{VAC} / \mathrm{Cm}^{2}$ and $\Gamma_{\text {max }}=0.27 \mu \mathrm{g}$ $\mathrm{VAC} / \mathrm{cm}^{2}$ for $0.5 \mathrm{mM}$ and $2 \mathrm{mM} \mathrm{Ca}+2$, respectively. The $\mathrm{P}-\mathrm{VAC}$ binding depends on the Ca+2-concentration (fig. 7). Half maximal binding, as measured with an excess of P-VAC lten times the kal is obtained at $0.4 \mathrm{~mm} \mathrm{Ca}{ }^{2+}$. 


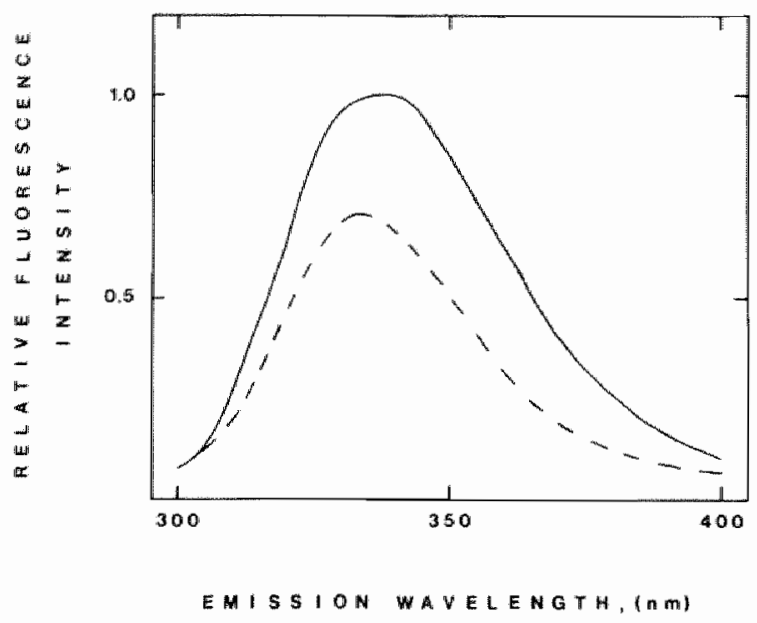

Eig. 8. Intrinsic fluorescence of P-VAC.

Emission spectra were made at $25^{\circ} \mathrm{C}$ in TBS. Excitation was at $285 \mathrm{~nm}$. The emission spectrum of active P-VAC in the absence of EDTA and $\mathrm{Ca}^{2+}$ was the same as it was in the presence of $1.5 \mathrm{mM} \mathrm{Ca} \mathrm{Ca}^{2+}$ or $1.5 \mathrm{mM}$ EDTA (----).

Emission spectra were also monitored of P-VAC, which was inactivated by a $5 \mathrm{~min}$ exposure to $56^{\circ} \mathrm{C}(-)$. No differences were observed between the emission spectra of inactivated P-VAC, in the absence of $\mathrm{Ca}^{2+}$ and EDTA, and in the presence of $1.5 \mathrm{mM} \mathrm{Ca} 2+$ or $1.5 \mathrm{mM}$ EDTA.

Emission spectra were monitored for several p-VAC concentrations. The concentrations of the active p-VAC, as well as those of the inactivated P-VAC, were linear with the integrated surfaces. of the corresponding emission spectra.

Since p-VAC shows a calcium-dependent binding to negatively charged phospholipids, we investigated whether a conformational change of P-VAC is required for binding by studying the effects of calcium and EDTA on the intrinsic fluorescence signal of P-VAC. At all concentrations tested (upto $5 \mathrm{~mm}$ ), both titrants did not alter the intrinsic fluorescence signal. Together with the observation that trypsin is unable to cleave p-vac either in the presence or in the absence of calcium, this indicates that $P-V A C$ does not undergo a conformational transition as a conse- 

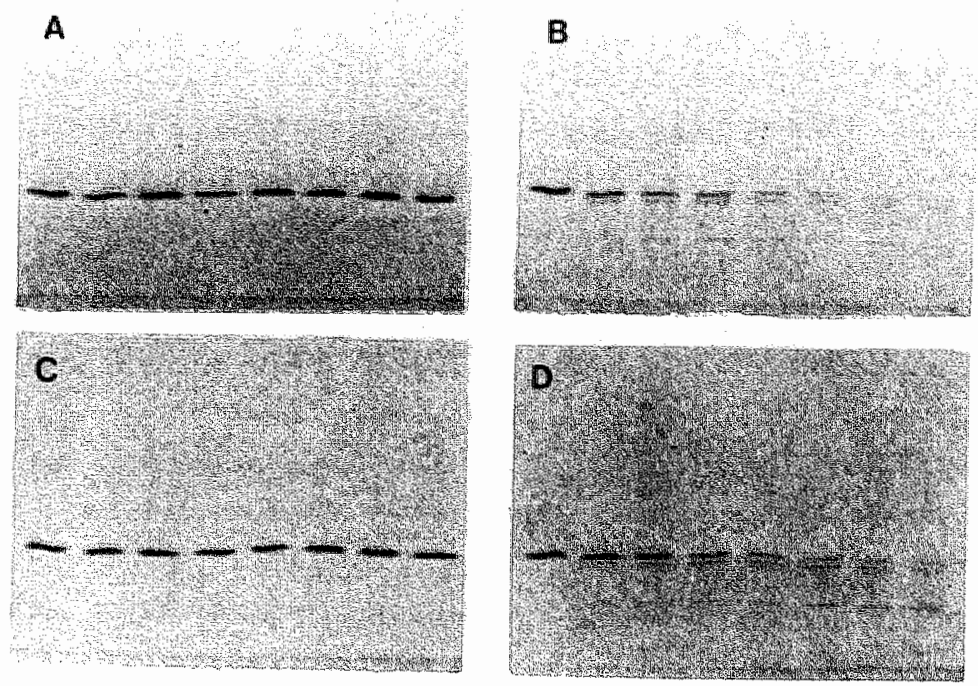

${ }_{10}^{20} 30^{40} 50^{60} 120$

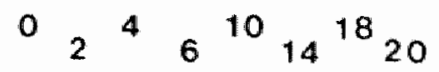

INCUBAT ION TIME, ( $\mathrm{min})$

Fig. 9. Effects of serine proteases on active P-VAC and heatinactivated $\mathrm{P}-\mathrm{VAC}$.

$25 \mu \mathrm{g}$ of active $\overline{\mathrm{P}}-\mathrm{VAC}$ was incubated with $0.1 \mu \mathrm{g}$ of trypsin at $37^{\circ} \mathrm{C}$. At the indicated time points, samples were witharawn, immediately boiled in SDS and subsequently submitted to gel electrophoresis, either under non-reducing (panel A) or reducing conditions (pamel $C$ ). The same procedure was carried out for P-VAC, which was inactivated by $5 \mathrm{~min}$. expasure to $56^{\circ} \mathrm{C}$ (B and D). Panel $\mathrm{B}$ presents gel electrophoresis under non-reducing conditions and panel $D$ shows the reduced gel. Identical incubations were performed with chymotrypsin and elastase. Both proteases cannot cleave the active P-VAC, but readily hydrolyze the inactivated P-VAC (gels not shown).

The incubations of P-VAC with the proteases were repeated with either $0.5 \mathrm{mM}$ EDTA or $0.5 \mathrm{mM} \mathrm{Ca} 2+$ being present. The electrophoretic patterns obtained from the incubations in the presence of one of these agents did not aiffer from the patterns obtained in their absence (not shown).

quence of calcium ions. The intrinsic fluorescence signal af P-VAC, however, could be increased upon exposure to $56^{\circ} \mathrm{C}$ (fig.8). This heat exposure also results in an inactivation af P-VAC. Together with the fact that trypsin, chymotrypsin and elastase could not cleave the active $P-V A C$, but readily cleaved the inactivated P-VAC (fig. 9), this suggests that the inactivation 


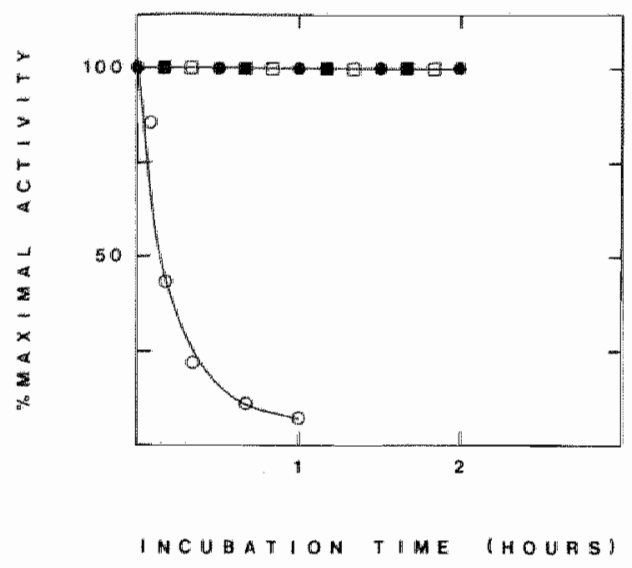

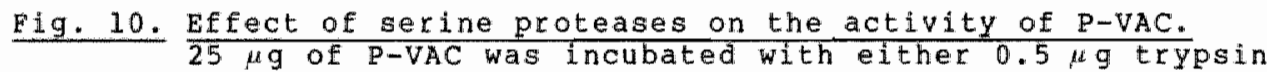
( ) $1,0.5 \mu \mathrm{g}$ chymotrypsin ( ) , $0.5 \mu \mathrm{g}$ elastase $(\square)$ or $0.5 \mu \mathrm{g}$ subtilisin $(\mathrm{O})$ ). At the indicated time points a sample was taken, that contained theoretically 2 units of VAC-activity, and was assayed in the MPT-test. The residual actiwity is expressed as percentage of the maximal activity. The amount of protease carried over from the incubation to the MPT-test, had no effect on its blank clotting time.

of P-VAC by heat exposure is associated with a conformational transition.

In contrast to trypsin, chymotrypsin and elastase, subtilisin, a serine protease from procaryotes, can inactivate native P-VAC (fig. 10$)$.

\section{DISCUSSION}

Vascular tissue of human umbilical cords contains an anticoagulant protein (VAC), that inhibits the phospholipid dependent factor $x_{a}$-catalyzed prothrombin activation 112 , chapter 2 of this thesis). Bovine aortic intima appears to contain a similar anticoagulant, a purification procedure of which has been developed (chapter 3 of this thesis). Part of its anticoagulant 
mechanism has already been unraveled: through a high affinity binding of VAC to phospholipids it interferes ith the assembly of prothrombinase complex on a negatively charged phospholipid surface. We have, furthermore, demonstrated the presence of VAC in endothelial cells, and have suggested that VAC is an intracellular extrinsic membiane protein, with still unknown physiological functions (chapter 5 of this thesis).

In this paper we demonstrate the presence of a similar anticoagulant in human placenta. Comparison of the placenta VAC (P-VAC) with the umbilical cord VAC (U-VAC) reveals that both proteins are likely to be identical. P-VAC and U-VAC have, apart from their similar molecular weights, comparable amino acid compositions. Furthermore, antibodies raised against u-VAC bind to P-VAC.

As to their anticoagulant activities, both vascular anticoagulants inhibit the factor $x_{a}$-catalyzed activation of prothrombin only when phopholipids are present. Moreover, both P-VAC, as well as U-VAC, lose their activities upon exposure to $56{ }^{\circ} \mathrm{C}$.

With the discovery of VAC in placenta a source of human VAC has been found that enables its purification in amounts sufficient for characterization of the protein, in spite of the fact that it is a minor component of the tissue.

We have developed a convenient and a rapid purification procedure for VAC, using a FPLC-system. Special columm and the increased working pressure shorten the puriflcation time considerably. Because af the stability of WAC at room temperature, this quick procedure permits the purification to be carried out at ambient temperature.

P-VAC and bovine VAC (chapter 3 of this thesis) show comparable affinities for a phospholipid surface, containing negatively charged phospholipids. Consequently their mechanisms of anticoagulant action are likely to be identical. This mechanism predicts an interference of VAC with the pholpholipid dependent intrinsic factor $x$-activation, since the organisation of the latter complex strongly resembles the structure of the prothrombinase $(14,17)$. In both complexes the phospholipids function as a membrare 
surface to which the vitamin k-dependent coagulation factors involved bind in a calcium dependent way (21-24).

$P-V A C$, indeed, inhibits the activation of factor $X$ by factor IXa, In the presence of phospholipids and factor VIIIa. Because the intrinsic factor $x$-activation preceeds prothrombinase in the coagulation cascade (6), VAC is, thus, more effective as an anticoagulant.

To gain insight in the mechanism of the binding of VAC to negatively charged phospholipids, we have inwestigated whether this binding requires a conformational change, as has been suggested for prothrombin $(26,27)$. To this end the effect of calcium and EDTA on intrinsic fluorescence was measured. Both compounds were without any effect. Since, moreover, the proteases, trypsin, chymotrypsin and elastase appeared to be unable to cleave VAC (both in the absence and presence of calcium), this strongly indicates that VAC does not show a calcium ion dependent conformational transition. Consequently, such a process is unlikely to be involved in the binding of VAC to negatively charged phospholipids.

The native tertiairy structure of VAC, however, is required for the phospholipid binding and for the anticoagulant activity, since inactivation of VAC by its exposure to $56^{\circ} \mathrm{C}$ was associated by a change in its tertiairy structure, as reflected by an increase of the intrinsic fluorescence. Moreover, the heat exposed VAC became susceptible to proteolytic attack by the serine proteases. Finally, the heat inactivated form of VAC does not bind to negatively charged phospholipids anymore lunpublished experiments).

Active VAC is not proteolytically cleaved by trypsin, chymotrypsin, and elastase. Regarding the preferential cleaving sites of these proteases, the conformation of the active VAC molecule is likely to have only few or no accessible arginine and lysine residues. Electrostatic farces between the latter and the negative charges in the phospholipid membrane are therefore unlikely to occur. Since VAC does not bind to pure phosphatidylcholine it can be excluded that predominant hydrophobic interac- 
tions with the membrane, as described for factor IX (27), are unlikely to occur between VAC and the phospholipid membrane. Active VAC can be cleaved by subtilisin, therefore, the VAC molecule probably contains quite some accessible glutamic acid and aspartic acid residues. Whether these are essential for the binding of VAC to the negatively charged phospholipias remains to be seen.

In conclusion we can say that VAC has a stabilized conformation with quenched intrinsic fluoresence. This conformation shows a calcium dependent binding to negatively charged phospholipids. A possible mechanism of this binding is the bridging of the calcium ions between the glutamic acid and/or aspartic acid residues of VAC with the negatively charged surface.

The real physiological function(s) of VAc is/are, as yet, unknown. However, the location of the protein in endothelial cells, can strategically implicate a function in anticoagulation. The importance of VAC as a physiological anticoagulant strongly depends on whether VAC is secreted by endothelial cells or whether exposure of VAC to plasma is only a result of cell injury. This is now under investigation.

\section{ACKNOWLEDGEMENTS}

The authors wish to thank drs. H. Soons (Maatricht) and drs. J Pieters (Maastricht) for providing them with the purified bovine coagulation factors. H. Van Eyck is acknowledged for the analysis of the amino acid mixtures, and P. Roszek for typing this manuscript.

\section{LITERATURE}

1. Hemker, H.C., Esnouf, M.P., Hemker, B.W., Swart, A.C.W., and Macfarlane, R.G. 1967. Nature 215:248-251.

2. Hemker, H.C., and Kahn, M.J.P. 1967. Mature 215:1201-1202.

3. Zwaal, R.F.A. 1978. Biochim. Biophys. Acta 515:163-205. 
4. Stenflo, J., and suttie, J.W. 1977. Annu. Rev, Biochem. $46: 157-172$.

5. Nemerson, Y., and Furie, B. 1980. CRC Crit. Rev. Bilochem. $9: 45-85$.

6. Jackson, C.M. and Nemerson, Y. 1980. Ann. Rev. Biochem. $49: 765-811$.

7. Govers-Riemslag, J.W.P., speyer, H., Zwaal, R.F.A., and Rosing, J. 1985. Thromb. Res. 38:375-388.

8. Nawroth, P., Kisie1, w., and stern, D. 1986. Thromb. Res. $44: 625-637$.

9. Thiagarajan, P., Shapiro, S.S., and De Marco, L. 1980. J. clin. Invest. $66: 397-405$.

10. Verheij, H.M., Boffa, M.C., Rothen, C., Bryckaert, M.S., verger, R., and de Haas, G.H. 1980. Eur. J. Biochem. $112: 25-32$.

11. Prigent-Dachary, J., Boffa, M.C., Boisseau, M.R., and Dufourg, J. 1980. J. Bio1. Chem. 255:7734-7739.

12. Reutelingsperger, C.P.M., Hornstra, G., and Hemker, H.C. 1985. Eur. J. Biochem. 151:625-629.

13. Sedmak, J.J., and Grossberg, S.E. 1977: Anal. Biochem. $79: 544-552$.

14. Van Dieijen, G., Tans, G., Rosing, J., and Hemker, H.C. I981 J. Bilol. Chem. 256, 3433-3442.

15. Vehar, G.A., and Davie, E.W. 1980. Biochemistry 19:401.

16. Van Dieijen, G., Van Rijn, J.L.M.L., Govers-Riemsiag, J.W.P., Hemker, H.C., and Rosing, J. 1985. Thromb. Haemost. $53,396-400$.

17. Rosing, J., Tans., Govers-Riemslag, J.W.P., Zwal, R.F.A., and Eemker, H.C. 1980: J. Biol. Chem. 255:274-283.

18. Tans, G., Janssen-Claessen, T., Van Dileijen, G., Hemker, H.C., and Rosing, J, 1982. Thromb. Haemost. 48:127-132.

19. Cuypers, P.A., Corse1, J.W., Janssen, M.P., Kop, J.M.M., Hermens, W. Th., and Hemker, H.C. 1983. J. Biol, Chem. $258: 2426-2431$.

20. Soons, H., Janssen-Claessen, T., Hemker, H.C., Tans, G. 1.986. Blood $68: 140-148$. 
21. Nelsestuen, G.L., Broderius, M., and Martin, G. 1976. J. Biol. Chem. 251, 6886-6893.

22. Nelsestuen, G.L., Kisiel, W., and DiScipio, R.G. 1970. Biochemistry $17: 2134-2138$.

23. Van Dieijen, G., Tans, G., Van Rijn, J.L.M.t., zwal, R.F.A., and Rasing, J. 1981. Biochemistry 20:7096-7101.

24. Van de Waart, P., Bruls, H., Hemker, H.C., and Lindhout, $I$. 1983. Biochemistry 22:2427-2432.

25. Nelsestuen, G.L. 1984. in Metal ions in Biological systems, (Sigel, H., Ed.) vol. 17, pp 353-380, Marcel Dekker Inc., New York.

26. Borowski, M., Furie, B.C., Bauminger, S., and Furie, B. 1986. J. Biol. Chem. 261:14969-14975.

27. Prigent-Dachary, J., Faucon, J.F., Boisseau, M.R., and Dufourq, J. 1986. Eur. J. Biochem. 156:133-140. 
CHAPTER 5

IMMUNOLOGICAL AND CHEMICAL DETECTION OF VASCULAR ANTICOAGULANT (VAC) IN CULTURED HUMAN

VASCULAR ENDOTHELIAL CELLS

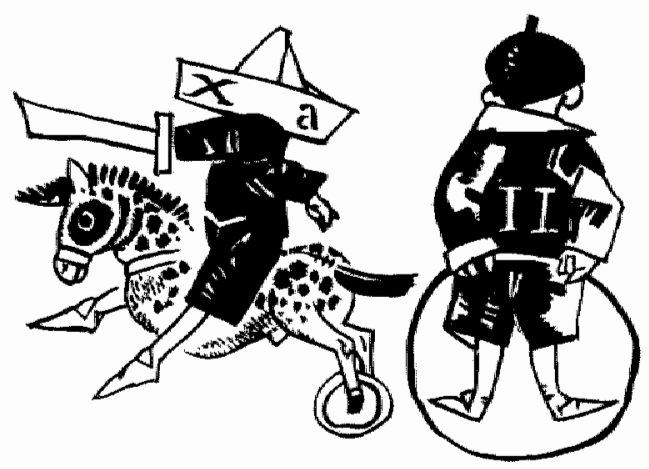



IMMUNOLOGICAL AND CHEMICAL DETECTION OF VASCULAR ANTICOAGULANT (VAC) IN CULTURED HUMAN VASCULAR ENDOTHELIAL CELLS

Reutelingsperger, C.P.M., Groenewegen, G., Huurman, W., Hornstra, G., and Hemker, H.C.

\section{SUMMARY}

Recently we have isolated from vessel wall homogenates a protein (VAC) with anticoagulant properties completely different from the known physiological antioogulants like antithrombin III and activated protein C (Eur. J. Biochem. 1985. 151:626-629).

By means of immunological and chemical techniques we now demonstrate qualitatively the presence of VAC in cultured human vascular endotheliai cells. Endothelial VAC appears to be an intracellular protein, which is not secreted in detectable amounts by quilescent endothelial cells. Whether or not VAC is synthesized de novo by the endothelial cell is not known at the moment. In the presence of I mM calcium, endothelial VAC binds to subcellular structures, thereby diminishing the procoagulant activities of these structures. Since the intracellular calcium content can become as high as $1 \mathrm{mM}$ in the case of cell injury, we hypothesise that WAC provides an anticoagulant mechanism, which locally competes ith the surface bound enzyme complexes of blood coagulation and thus controls thrombin formation at sites of damaged endothelial cells. 


\section{INTRODUCTION}

Endothelial cells in culture, originating from various vascular tisaues, play a dual rale in hemostatic pcocesses. The endothelial cell surface supplies the antithrombin II anticoagulant pathway with heparin-1ike structures (1). Moreover, the protein $C$ anticoagulant pathway is supplied with thrombomodulin (2), protein s (3), and cofactor activity for the assembly of the activated protein C - protein s complex (4).

Apparentiy in contradiction, the endothelial cell surface also can propagate a sequence of procoagulant reactions leading to. fibrin formation $(5-7)$.

The perception of this duality has led to a concept of a balance of procoagulant and anticoagulant reactions occurring at the endothelial cell surface. Non-perturbed endothelial cells favour the anticoagulant reactions, this can be reversed upon exposing the cells to perturbing agents, like tissue necrosis factor (8) and interleukin $\mathbb{1}$ (9).

A disturbance is also likely to accur in case of endothelial cell damage. Procoagulant activities, associated with intracellular structures $(10-12)$, will then be exposed to the plasma.

up till now, no anticoagulant mechanisms are known that become active after cell injury and that contribute to a normalization of the disturbed procoagulant - anticoagulant balance.

This study describes the presence in endothelial cells of a recently discovered (13) vascular anticoagulant (VAC), which binds in the presence of calcium to negatively charged phospho$11 \mathrm{pids}(14)$. As a consequence of this binding, the phospholipid dependent procoagulant reactions lintrinsic factor $x$ - and the prothrombin activation) are inhibited by VAC. In this article we demonstrate that the endothelial VAC binds in the presence of calcium to intraceliular structures and, thereby, inhibits the procoagulant activities of these structures. Based on these features, we propose that VAC provides an anticoagulant mechanism, which can control thrombin formation at sites of damaged endothelial cells. 
MATERTALS AND METHODS

proteins - A standard pool of human platelet free plasma (PFP) was prepared (13). Human brain thromboplastin was isolated following the method described by van Dam-Mieras et a1. (15).

VAC was purified from carefully dissected human umbilical cord arteries in a way identical to the purification procedure of bovine VAC (14). The purified preparation was homogenous for the $M r=32,000$ band as judged with polyacrylamide gel electrophoresis in the presence of sodium dodecyl sulfate (SDS-PAGE). The modified prothrombin time test (MPT-test) employed for quantifying of VAC-activity, has been described in detail in (13).

Antibodies - Normal swine serum and horse radish peroxidase (HRP) - labeled swine anti-rabbit IgG were purchased from DAKO (Denmark). Rabbit antibodies to human VAC were produced with standard techniques: Rabbits were injected subcutaneously with $500 \mu \mathrm{g}$ purified human VAC in $1 \mathrm{ml}$ Freund's complete adjuvant. After four weeks, rabbits were boostered with $100 \mu g$ of purified VAC in Freund's incomplete adjuvant. Boosters were repeated four times with two week intervals. Finally, the rabbit serum was collected and fractionated with 35 ammoniumsulfate precipitation. The precipitated proteins were dialyzed into Tris-buffered saline (TBS, $50 \mathrm{mM}$ Tris/HCl, $\mathrm{pH} 7.9,100 \mathrm{mM} \mathrm{NaCl}$ ) and subsequentIy applied to a DEAE-Sephadex column (Pharmacia, Uppsala sweden), which was equilibrated with TBS. The unbound protein fraction, containing the anti-VAC antibodies, is referred to as purified $a-V A C A b$.

Cell culture - Endathelial cells derived from human umbilical cord veins were prepared according to the method of Thornton (16) as modified in our laboratory (17). In brief, after harvesting endothelial cells from the vein of the umbilical cord by collagenase digestion, the cells were cultured in flasks pretreated with fibronectin in RPI 1640 tissue culture medium supplemented with 20 human serum and growth factors. Cultures were characterized 
as endothelial cells based on morphology, presence of angiatensin converting enzyme and presence of factor VII related antigen/von ill Lebrand antigen.

Fractionation of endotbelial cells - confluent cell cultures (passage 2 and 3 ) were washed three times with ice cold TBS. Following the 1 ast wash, cold homogenization buffer $10.25 \mathrm{M}$ sucrose, $10 \mathrm{mM}$ Tris/ HCl. pH 8.1, 1 m leupeptin (Boehringer Mannheim, Wermany), $1 \mathrm{mM}$ EDTA or $1 \mathrm{mM} \mathrm{CaCl} 2$ ) was added and the cells were removed from the surface of the flask with a rubber policeman. The suspended cells were homogenized using a tight fitting teflon pestle tissue grinder (Braun-Melsungen, W. Germany . The homogenates were submitted to differential centriEugation, following the scheme depicted in fig. I, in a Beckman Th-100 table top ultracentrifuge. Pellets were resuspended in a valume of TBS, which equals the starting volume of the homogenate. Homogenization and fractionation were carried out at $00 \mathrm{C}$. Protein contents of the different fractions were determined following the method as described by sedmak (18). Lactate dehydrogenase activity was assessed by the procedure of Wroblewski (19).

Electrophoresis and immunoblotting - SDS-PAGE was carried out as described by Laemil (20) on slab gels containing 10 acry amide, 0.27 o $\mathrm{N}^{3}$-methylenebisacrylamide and 0.1 SDS. The gels were either stained with Comassie Brilliant Blue (13) or used for immunoblotting as described by rowbin et ad. (21). Proteins were electrophoretically transferced from the gel into a nitrocellulase paper (Bio-Rad Richmond, California). The part of the paper into which the marker proteins were blotted, was stained with Amido Black. The rest of the paper was incubated for one hour at $370 \mathrm{C}$ with phosphate buffered saline (PBS, $10 \mathrm{mM}$ $\mathrm{KH}_{2} \mathrm{PO}_{4} / \mathrm{K}_{2} \mathrm{HPO}_{4}, \mathrm{pH} 7.4,150 \mathrm{mM} \mathrm{NaCl}, 0.02 \mathrm{o}(\mathrm{v} / \mathrm{v})$ Tween-20, and 1 mg/ml bovine serum albumine) containing 0.2 gormal swine serum. subsequentiy the paper was incubated for another hour at $37^{\circ} \mathrm{C}$ wh th $\mathrm{PBS}$, containing a-VAC Ab $(25,1 \mathrm{~g} / \mathrm{mL})$. After this period, the 


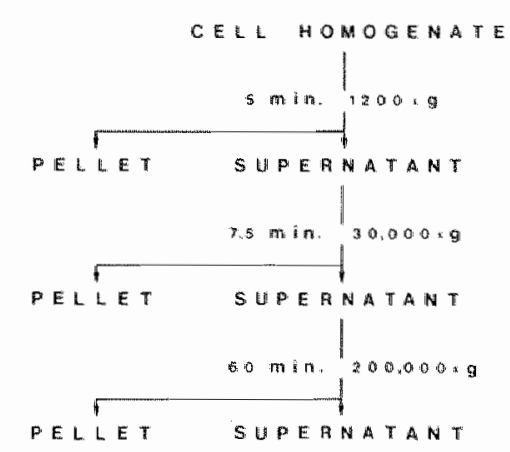

Fig. 1. Differential centrifugation scheme.

Homogenates, which were prepared from endothelial cells as described in materials and methods, were submitted to differential centrifugation following the above depicted routine. Centrifugation was carried out at $0^{\circ} \mathrm{C}$ in a Beckman TL-100 table top ultracentrifuge. Pellets were resuspended in TBS with a volume, which equals the starting volume of the homogenate.

paper was rinsed with PBS, and further incubated for one hour at $37^{\circ} \mathrm{C}$ with HRP-labeled swine anti-rabbit IgG, alituted 1:500 in PBS. The paper was rinsed free of unbound HRP-labelled IgG, and the bound HRP-labeled Ab was visualized by incubating the paper with $0.5 \mathrm{mg} / \mathrm{ml}$ DAB 13,3 -diamino-benzidinetetra-chloride, Fluka AG Buchs, Switzerland) in $50 \mathrm{mM} \mathrm{Tris/HCl,} \mathrm{pH} 7.5,0.025 \mathrm{H}_{2} \mathrm{O}_{2}$. In each immunoblot experiment a) omission of a-VAC Ab, b) replacement of a-VAC Ab by preimmune rabbit serum, and cl employment of a-VAC Ab, which was preincubated with purified VAC, were included as controls. In one experiment (fig. 2a) electrophoresis was carried out with ready-prepared polyacrylamide gradient gels (10-158) from Pharmacia in the Pharmacia phast system. Following electrophoresis, the proteins in the gel were transferced by aiffusion into nitrocellulose paper at $37^{\circ} \mathrm{C}$. The paper was further pracessed as described above.

Immunofluorescence and immunoperoxidase staining - Immunofluorescence was used for localisation of VAC on the cell-surface and in 


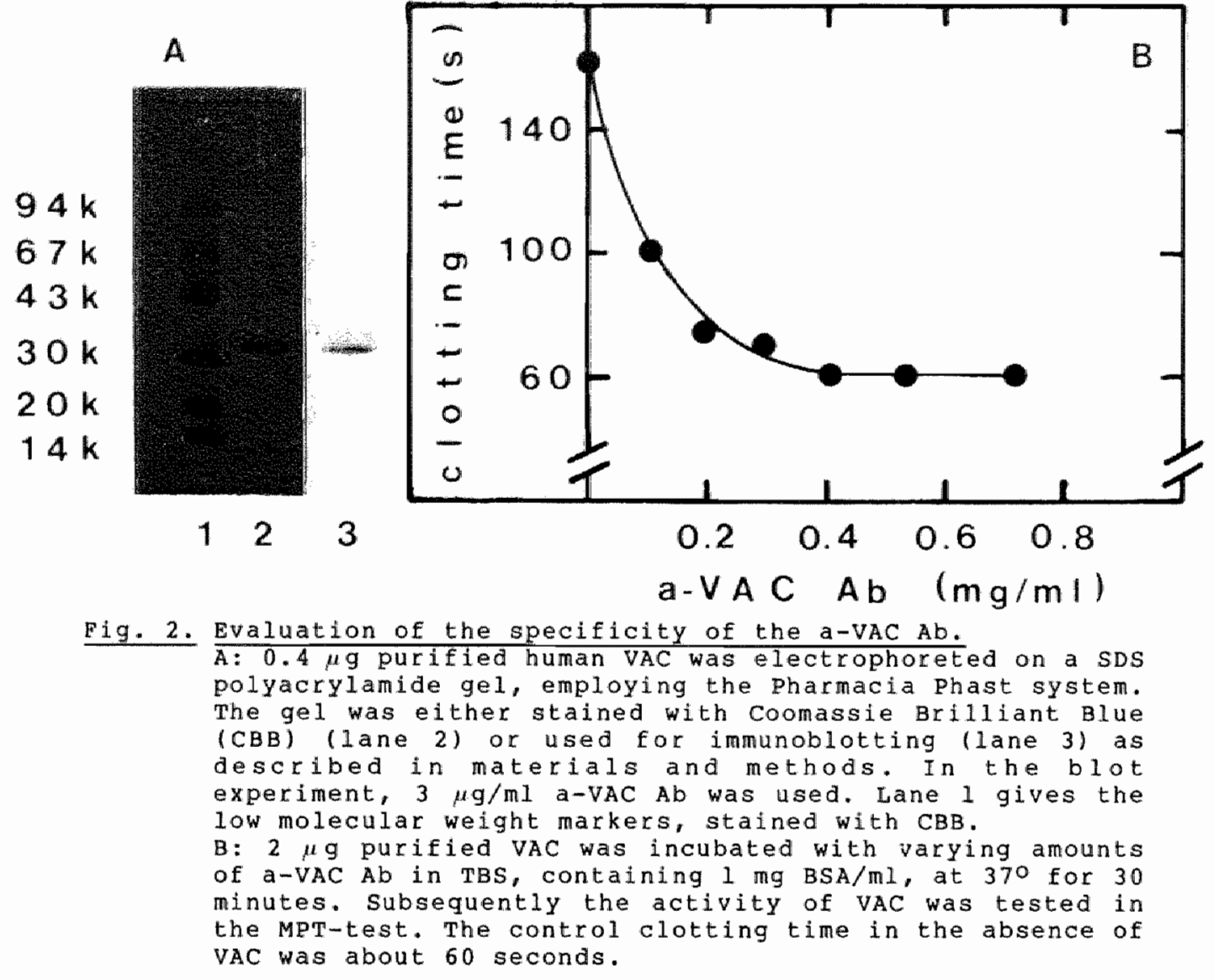

the cytoplasma. For detection of cell-surface bound VAC, endothe1ial cells were detached from culture flasks with EDTA and subsequentiy transferred into PBS, containing 0.18 BSA and $0.01 \%$ $\mathrm{NaN}_{3}$. Intracellular fluorescence for detection of VAC within the cells was assessed by making the cells permeable for the reagents by fixation with 708 ethanol 1 in ice for 30 minutes under constant stirring. Subsequently, the intact and the fixed cells were incubated with a-VAC $A b$, washed 3 times, and incubated with swine anti-rabbit IgG, labeled with FITC. Following this incubation, the cells were washed 3 times and the fluorescence of the cells as read on a FACS IV (Beckton and Dickenson, Sunny Vale, Los 
Angelos). Controls consisted of cells treated with rabit anti-dog IgG (as nonspecific control) and subsequent incubation with fluorescent conjugate.

Immunoperoxidase staining of ethanol fixed endothelial cells was performed on endothelial cells, cultured on slides and fixed as described above. The cells were first incubated with a-VAC Ab. and after 3 washes, with swine anti-rabbit IgG, labelled with peroxidase. The visualization occurred with DAB. The cells were counterstained with hematoxiline and mounted as usual.

\section{RESULTS}

Characterization of the a-VAC Ab - The purified a-VAC Ab, obtained from the serum of rabbits as described in the materials and methods, was tested for its reactivity with purified VAC in an immunoblot experiment and in the MPT-test. Both tests revealed that the a-VAC $A b$ reacts with the purified VAC molecule: the a-VAC Ab not only binds to purified VAC (fig. 2A) but also inhibits in a dose-dependent manner the anticoagulant activity of VAC (fig. 2B). The specificity of the a-VAC Ab was examined by immunoblotting the protein contents of a vessel wall homogenate, prepared from human umbilical cord arteries. The immunablot (fig. 3) shows that the a-VAC Ab reacts with a $32 \mathrm{k}$ daltons band, which comigrates with purified VAC.

Control immunoblots were all negative. Minor cross reactions can be observed with some other proteins present in the homogenate. Immunoblat analysis of vessel wall homogenates, prepared from aortas of other species than man, reveals that horse and $r a t$ aorta contain a $32 \mathrm{k}$ daltons protein, which is recognized by the $a-V A C A b$, and bovine aorta contains a $32 k$ daitons and a $34 k$ daltons bard, which react with the a-VAC Ab.

Detection of VAC in cultured human endothelial cells - Using the immunoblot technique, it was demonstrated that homogenates of human umbilical cord venous endothelial cells (Huve) contain a $32 k$ daltons antigen which is recognized by the a-VAC Ab and which 
E19. 3: Evaluation of the spe$\frac{\text { cificity of the a-VAC Ab. }}{\text { The human umbilical cord arte- }}$ $r$ ies were homogenized in cold TBS, containing 1 mM EDTA. The homogenate was centrifuged for $6,000 \times$ gmin. at $00 \mathrm{C}$. The resulting supernatant was submitted to SDS-RAGE. The separated protedns were either stalined with CBB (lane 3) or transferced into nitrocellulose paper, which was thereafter treated with a-VAC Ab $(3 \mu \mathrm{g} / \mathrm{ml})$ as described in materials and methods (1ane 2). Lane 1 represents $1 \mu \mathrm{g}$ of purified VAC, and lane gives the CBB stained low molecular weight markers.

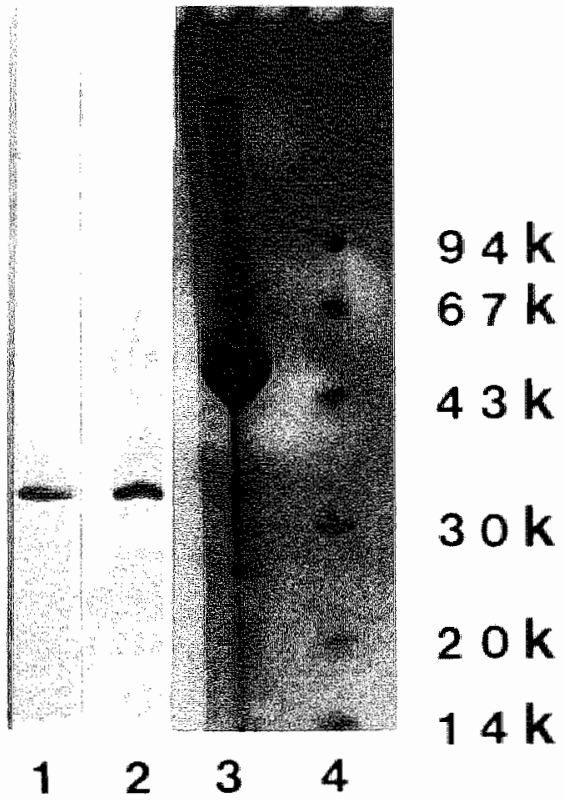

Fig. 4. Im m u n o chemica 1 detection of WAC in cultured endothelial cells.

$10^{\circ}$ Confluent endothelial cells were homogenized in homogenization buffer, containing $1 \mathrm{mM}$ EDTA. The proteins in the homogenate were separated with sDSPAGE and subsequenty staimed with CBB (Iane 1) or immunobloteed with 3 is 9 a-VAC Ab/mi (lane 4). Lane 5 contains 1 Mg of immunoblotted puriefied VAC. Lane 2 and 3 give the low molecular wejght markers. Lane 2 was stained with CBB, and lane 3 was first blotted into nitrocellulose paper and subsequently stained with Amido black. 


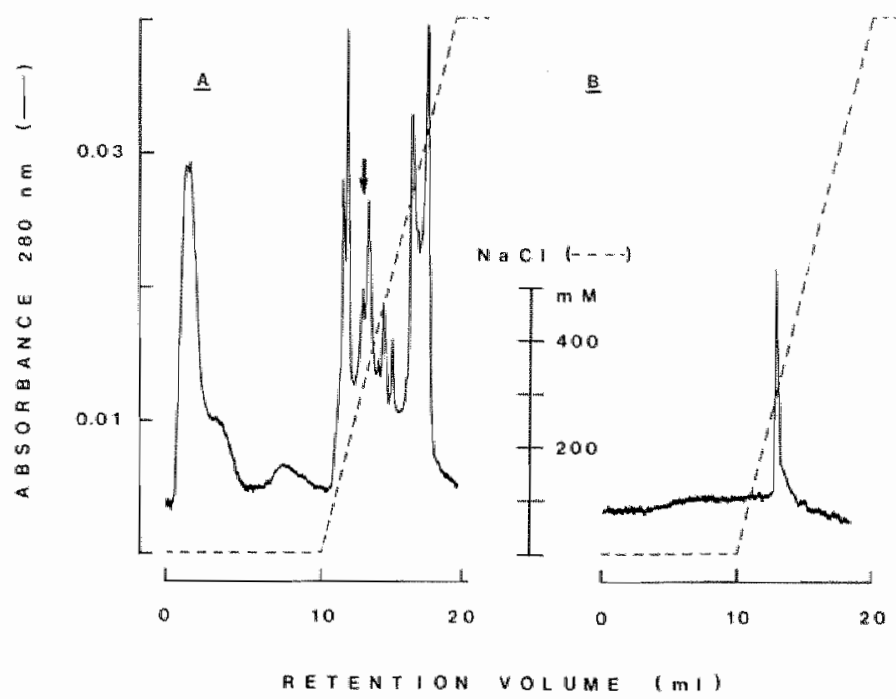

Fig. 5: Chromatography of lyzed endothelial cells and purified VAC on the anion exchanger Mono.

A) $10^{6}$ confluent endothelial cells were resuspended in 20 $\mathrm{mM}$ bis-Tris/HCl, $\mathrm{pH} 6.3$, and lyzed by 3 cycles of freezing and thawing. The lysate was submitted to chromatography on Mono $Q$. The 1 inear $\mathrm{NaCl}$ gradient was constructed in $20 \mathrm{mM}$ bis-Tris/HCl, pH 6.3. The fractions $1160 \mu 1$ each) were analyzed with immunablotting using a-VAC Ab. The VAC-antigen eluted at $300 \mathrm{mM} \mathrm{NaCl}$ with a retention volume, which is indicated by the arrow.

B) $8.5 \mu \mathrm{g}$ purified VAC was submitted to chromatography on Mono $Q$ with conditions identical as under $A$. The fractions were tested in the MPT-test for VAC-activity, which co-elutes with the protein peak.

comigrates with purified VAC (fig. 4). Control immunoblots were negative. Since it is most likely that this antigen represents the VAc-molecule, the antigen was further characterized by chromatography on Mono Q. A homogenate of Huve was applied to the Mono $Q$ column at a $100 \mathrm{mM}$ NaCl concentration. A linear gradient of Nacl was employed for elution of the bound proteins. Immunoblot analysis of the eluted fractions revealed that the $32 \mathrm{k}$ daltons antigen elutes from the Mono $Q$ column with a $300 \mathrm{mM}$ NaCl concentration (fig. 5A), which is the concentration required for 
Table 1

Effect of subcellular fractions of endothelial cell homogenates on the recalcification time of citrated platelet free plasma: influence of EDTA and calcium.

\begin{tabular}{|c|c|c|c|}
\hline EDTA-fractionsa & $\begin{array}{l}\text { oteinb } \\
(\mu g)\end{array}$ & $\left(\begin{array}{c}\mathrm{LDHC} \\
\text { of tataI })\end{array}\right.$ & $\begin{array}{c}\text { clotting timed } \\
\text { (s) }\end{array}$ \\
\hline $\begin{array}{l}6,000 \times \text { gmin. pellet } \\
227,000 \mathrm{x} \text { gmin. pellet } \\
12.10^{6} \mathrm{x} \text { gmin. pellet } \\
\text { vesicle free supernatant } \\
\text { blank }\end{array}$ & $\begin{array}{l}6.0 \\
5.0 \\
6.0 \\
20.0 \\
-\end{array}$ & $\begin{array}{l}3 \\
1 \\
2 \\
94 \\
-\end{array}$ & $\begin{array}{l}228 \\
252 \\
684 \\
1900 \\
1100\end{array}$ \\
\hline $\begin{array}{l}\text { Calcium-fractionsf } \\
6,000 \times \text { gmin. pellet } \\
227,000 \times \text { gmin. pellet } \\
12.106 \times \text { gmin. pellet } \\
\text { vesicle free supernatant } \\
\text { biank }\end{array}$ & $\begin{array}{l}9.0 \\
7.5 \\
8.0 \\
1.1 .5 \\
-\end{array}$ & $\begin{array}{l}4 \\
1 \\
1 \\
94 \\
-\end{array}$ & $\begin{array}{l}432 \\
456 \\
786 \\
1020 \\
1100\end{array}$ \\
\hline
\end{tabular}

$10^{6}$ endothelial cells were homogenized in $400 \mu 1$ homogenization buffer as described in material and methods, either in the presence of $1 \mathrm{mM} E D T A$ (a) or in the presence of 1 MM calclum (f). The homogenates were fractionated as described in fig. 1. The pellets were resuspended in $400 \mu 1$ TBS. b protein contents were determined according to the method of sedmak (18). C Lactate dehydrogenase activity was assessed following the method described by Wroblewski (19). d $75 \mu 1$ of a fraction was added to $50 \mu 1$ citrated platelet free plasma. The mixtures were stirred at 370 C. At time point zero prewarmed calcium-containing buffer was added. Final volume of the reaction mixture was $500 \mu 1$ and final calcium concentration was $10 \mathrm{mM}$. Clotting is monitored optically (13). Blank clotting time is about $1100 \mathrm{~s}$. e preincubation of an aligout of this fraction with a-VAC Ab results in a reduction of the clotting time to its blank value. The data are the mean of two separate experiments.

protein concentration and lactate dehydrogenase activity (table 1). Furthermore aliquots of the fractions were added to citrated normal human platelet free plasma, which was thereafter recalcified. Resulting clotting times are given in table 1 . The intracellular structures significantly shorten the clotting time of the recalcified plasma. Intracellular structures prepared in the presence of calcium, however, possess less procoagulant 
activity in comparison with the structures prepared in the presence of EDTA. This diminished procoagulant activity coincides ith the presence of the VAC antigen in these fractions (fig. 6). on the other hand the wesicle free fraction, prepared in the presence of calcium, lacks an anticoagulant activity (table 1) as we 11 as the VAC antigen (Eig. 6). In contrast to this, the vesicle Eree EDH fraction prolongs the clotting time and contains the VAC antigen. This prolongation of the clotting time 1 prevented by incubating the vesicle free EDTA fraction with a-VAC Ab prior to adition to the pFP. These results demonstrate that the VAC antigen and the purified VAC are identical, moreover, the endothelial VAC lowers the procoagullant activities of intracellular structures.

Preliminary studies on the localization of VAC in the endothelial cell - In the previous section we have described the presence of VAC in HUVE and its attachment to intracellular structures in the presence of $1 \mathrm{mM}$ calcium. This condition does not represent the physiological situation of the intact cell, which maintains a free calcium concentration of about $0.1 \mathrm{M}$. To get an insight in the localization of VAC within HUVE, we have conducted immunofluorescence studies on EUVE using $a-V A C A b$. The FACS data show, that VAC is not present in detectable amounts on the surface of the HuVE. However, fixed cells, permeable Eor the a-VAC Ab, show significant increase in fluorescence intensity (fig.7). Immunoperoxidase staining of HUVE with a-VAC Ab reveals a perinuclear staining, which is granular and diffuse over the cytoplasm leig. B). Immunoperoxidase staining on intact cells is negative using a-VAC $A B$, (data not shown).

The presence of VAC in other vascular cells - Cell homogenates prepared from cultured human omentum capiliary endothelial cells and human aortic smooth muscle cells were submitted to immunoblotting as described for Huve homogenates. Also these cells appear to be positive for the $32 k$ daltons antigen. These results indicate that the presence of VAC is not restricted to the endothelial cell, which is derived from the human umilical cord vein. 

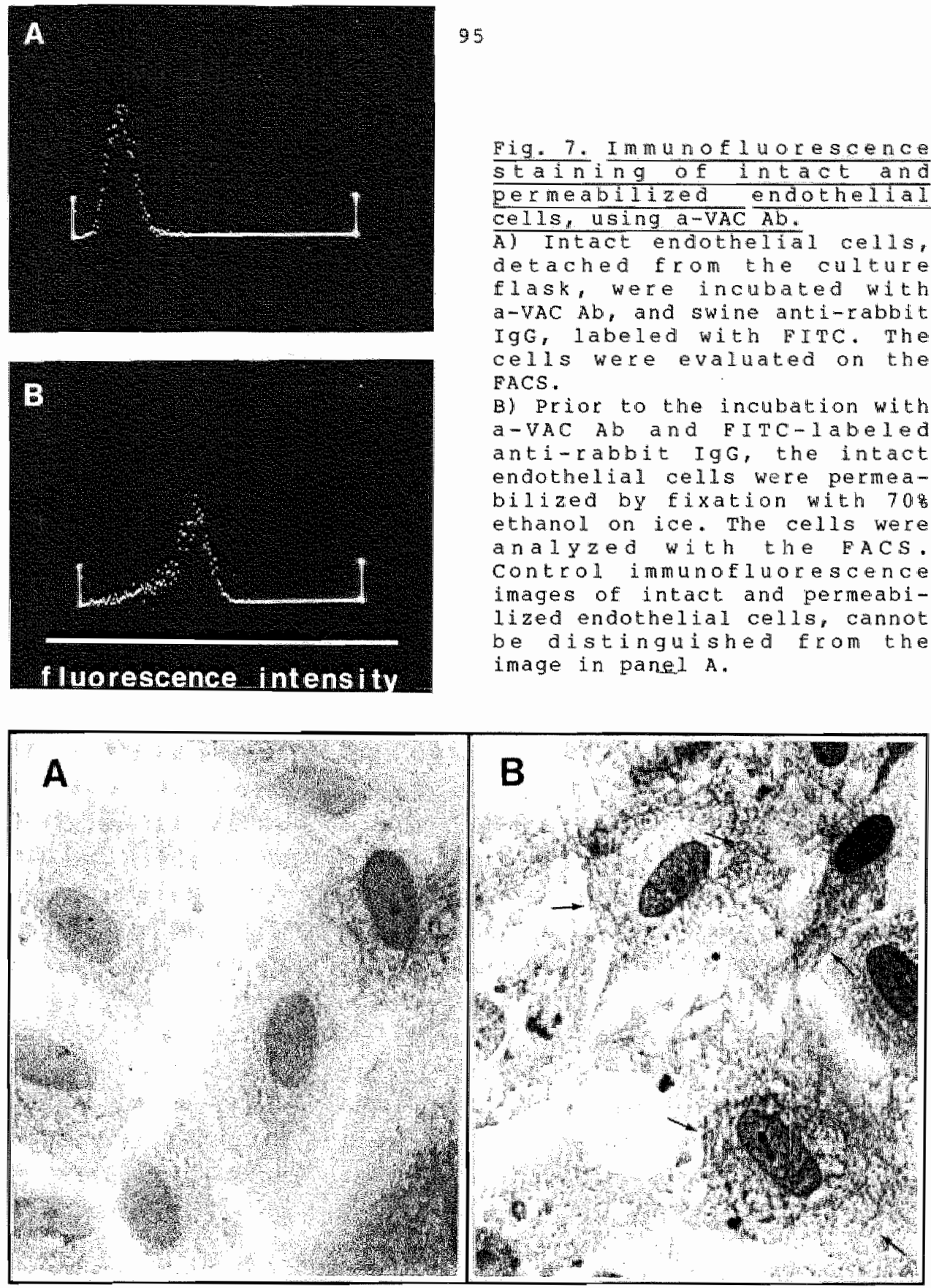

pig. 8: Immunoperoxidase staining of spread permeabilized endothelial cells.

Endothelial cells, spread on gelatin coated glass cover slips, were made permeable for antibodies with ethanol fixation, and subsequentiy incubated with preimmue serum (A) or with a-VAC Ab (B), and swine anti-rabbit IgG, conjugated with horse radish peroxidase. The arrow indicate some of the granulated brown precipitates.

Fig. 7. Immunothorescence staining of intact and permeabilized endoth ceIls, using a-VAC $\overline{A b}$.

detachea from the culture Elask, were inctibat a d w $a-W A C A b$, and swine anti-rabbit IgG, labeled with FTC. The cells were evaluated on the FACS.

B) Prior to the incubation with $a-V A C A B$ and FITC-1abeled $a n t i-r a b b i t$ IgG, the ntact endothelial cells were permeabilized by fixation with 70 ethanol on ice. The cells were ana $1 \mathrm{y} z \in \mathrm{d}$ w $\mathrm{t} h \mathrm{the} \mathrm{FACS}$. control immunafuorescence Images of intact and permeabilized endothelial cells, cannot be distinguished from the image in panel A. 


\section{DISCUSS ION}

The discovery in vessel wall homogenates of a unique anticoagulant activity and the elucidation of lts assosiation with a single chain protein (VAC) with $M r=32,000$ (13), have prompted us to investigate the localization of VAC in the vessel wa1l. This paper reports on this study, which is conducted with immunological and chemical techniques, applied to cultured vascular endothelial cells.

Recently, a complete purification procedure (14) for VAC was established using bovine aorta, which contains an anticoagulant activity similar to that found in human umbilical cord arteries (13). Application of this procedure using human umbilical cord arteries as a source, results in a purified vac preparation, which is homogenous for a $32 \mathrm{k}$ daltons protein. Rabbits immunized with this purified VAC gave rise to IgG antibodies, which bind to the purified VAC and which inhibit the anticoagulant activity of purified VAC, as was judged from immonoblotting studies and functional tests, respectivily. The antibodies bind to a $32 \mathrm{k}$ daltons antigen, which is present in the homogenate prepared from human umbilical cord arteries and which comigrates with the purified VAC. Minor cross reactions of the antibodies with other proteins, present in the homogenate, are observed. These findings indicate that we have obtained a polyclonal IgG preparation (a-VAC Ab), which recognizes specifically the vac molecule.

In order to obtain an insight in the localization of VAC in the vessel wall, we have employed the a-VAC Ab in immunoblotting studies, in which lysates of cultured cells were used. We have focussed this study on endothelial cells. Endothelial cells, derived from human umbilical cord veins (Huve), appeared to contain a $32 \mathrm{k}$ daltons antigen, which comigrates with purified VAC. Besides the similarity in molecular weight, this antigen and VAC share various other features:

1) Both the antigen and VAC bind reversibly in the presence of calcium to intraceliular structures.

2) The interaction of both substances with the anionic resin 
Mono $Q$ is identical, indicating similarties in physical properties.

3) The antigen cofractionates with an anticoagulant activity" which can be inhibited with a-VAC Ab, suggesting that the anticoagulant activity is coupled to the antigen.

These findings clearly demonstrate the presence of VAC in cultured endothelial cells. Whether or not the endothelial VAC originates from de novo synthesis is unknown. Studies to elucidate this topic, are under way. The presence of VAC in the cell may implicate (a) physiological function(s) of VAC, which is/are not clear at the moment. From the localization of VAC as well as on the basis of its phospholipld-binding characteristics, VAC can be classified as an extrinsic membrane protein, and thus, VAC might play a role in membrane dependent processes. At present we know that, due to its high affinity for negatively charged phospholipids (14), VAC inhibits the phospholipid dependent activation of prothrombin by factor $x_{a}$ and calcium $(13,14)$, and the phospholipid dependent activation of factor $x$ by factor $I_{a}$ and calcium (chapter 4 of this thesis).

The distribution of VAC in the cell differs strikingly from that of the secretable proteins, von willebrand factor (22) and protein $S(3)$. Together with our fallure to detect vac in the cell-conditioned medium and the absence of VAC at the outside of the plasma membrane, the intracellular localization of VAC apparently precludes a function for VAC as an physiologlical active extracellular anticoagulant. However, the employed endothelial cells in the secretion study were quiescent, indicating, that VAC is not secreted constitutively, but not excluding the secretion of an intracellular pool of VAC upon cell perturbation. Furthermore, factor $v$, which is demonstrated to be secreted by endothelial cells (23), shows an intracellular distribution, which resembles the distribution of VAC. Therefore, further studies have to be undertaken to elucidate whether under certain conditions VAC can be secreted by endothelial cells.

The data obtained so far indicate that intracellular VAC may play a role in hemostatic processes following cell damage. Intracel- 
lular structures, which then become accessable to plasma and which probably consist of intracellular membranes, a Hageman factor activating compound (12) and tissue factor $(10,11)$, excert a procoagulant activity. It is likely that the negatively charged phospholipids of these structures play an accelerating role in the procoagulant reactions. Our study, in which we measured the procoagulant activity of the intracellular structures, prepared in the presence of calcium or EDTA, demonstrates that endothelial VAC, which is bound to intracellular structures in the presence of calcium, diminishes the pracoagulant activity of these structures. However, this procoagulant activity is not completely blocked by endogenous VAC, indicating that there is not sufficient VAC present for complete inhibition and/or the intracellular structures exhibit a procoagulant activity, which cannot be inhibited by VAC.

The demonstration in endothelial cells of the presence of VAC with an anticoagulant activity, adds a new possibility to the list of anticoagulant mechanisms through which endothelial cells can modulate thrombin formation. VAC provides protection against a surplus of procoagulant phospholipids at the site of a wound.

\section{ACKNOWLEDGEMENTS.}

The authors wish to thank $T$. Jeunhomme and I. Dieteren for their skillful technical assistance, Dr. P. de Groot (utrecht, the Netherlands) and Dr. T. Muller (Biberach, W. Germany) for kindly providing them with smooth muscle cells, and omentum capiliary cel1s, respectively. P. Roszek is acknowledged for typing this manuscript.

\section{LITERATURE}

1. Marcum, J.A., J.B. Mckinney, and R.D. Rosenberg. 1984. J.Clin.Invest. $74: 341-350$. 
2. Esmon, W.L., W.G. Owen, and C.T. Esmon. 1982. J.Biol.Chem. $257 ; 859-864$.

3. Stern, D.M., Brett, K. Harris, and P. Nawroth. 1986. J.Ce11.Biol. 102:1971-1978.

4. Stern, D.M., P.P. Nawroth, K. Harris, and C.T. Esmon. 1986. J.Biol .Chem. 261:713-718.

5. Colucci, M., G. Balconi, R. Lorenzet, A. Pietra, D. Locati, M. Donati, and P. Sormeraro. 1983. J.Clin.Invest. $71: 1893-1896$.

6. Bevilaqua, M., J.S. Pober, G.R. Majean, R.S. Cotran, and M.A. Gimbrone. 1984. J.Exp.Med. 160:618-620.

7. Rodgers, G.M., and M.A. Shuman. 1983. Proc. Nati. Acad. Sci. USA $80: 7001-7005$.

8. Nawroth, P.P., and D.M. Stern. 1986. J.Exp.Med. 163:740-745.

9. Nawroth, P.P., D.A. Handley, C.T. Esmon, and D.M. stern. 1986. Proc.Nat1.Acad.Sci.uSA. 83:3460-3454.

10. Maynard, J.R., B.E. Dreyer, M.S. Stemerman, and F.A. Pitlick 1977. Blood $50: 387-396$.

11. Lyberg, T., K.S. Galdal, S.A. Evensen, and H. Prydz. 1983. Brit. J. Haematol. 53:85-95.

12. Wiggins, R.C., D.J. Loskutoff, C.G. Cochrane, J.H. Griffin and T.S. Edgington. 1980. J.Clin. Invest. 65:197-206.

13. Reutelinsperger, C.P.M., G. Hornstra, and H.C. Hemker. 1985. Eur.J.Biochem. 151:625-629.

14. Reutelingsperger, C.P.M., J.M.M. Kop, G. Hornstra, and H.C. Hemker. 1987. submitted for publication.

15. Van Dam-Mieras, M.C.E., A.D. Muller, G. van Dieyen, and H.C. Hemker. 1984. In Methods of Enzymatic Analysis. (Bergmeyer, H.U., ed.). Vol 5: pp 325-365. Verlag Chemie GmbH, Weinheim.

16. Thornton, S.C., S.N. Mueller, E.M. Levine. 1983. Sclence $222: 623-625$.

17. Groenewegen, G.. W.A. Burman, and C.J. van der Linden. 1985. Clin. Immuno1. Immunopathol. $36: 378-385$.

18. Sedmak, J.J., and S.E. Grossberg. 1977. Analyt.Biochem. $79: 544-552$. 
19. Wroblewski, R., J.S. La Due. 1955. Proc.Soc.Exp.Biol.Med. $90: 210-215$.

20. Laemil, U.K. 1970. Nature (Lond.) 227:680-685.

21. Towbin, H., T. Staehelin, and J, Gordon. 1979. Proc.Nat1. Acad.Sci.USA $76: 4350-4354$.

22. Wagner, D.D., J.B. Olmsted, and V. Marder 1982. J.Cel1.Biol. $95: 355-360$.

23. Cerveny, T.J., D.M. Fass, and K.G. Mann. 1984. Blood $63: 1467-1474$. 
CMAPTER 6

A NEW HOMEOSTATIC MECHANISM TO CONTROL THROMBIN FORMATION AT THE VESSEL WALL LEVEL.

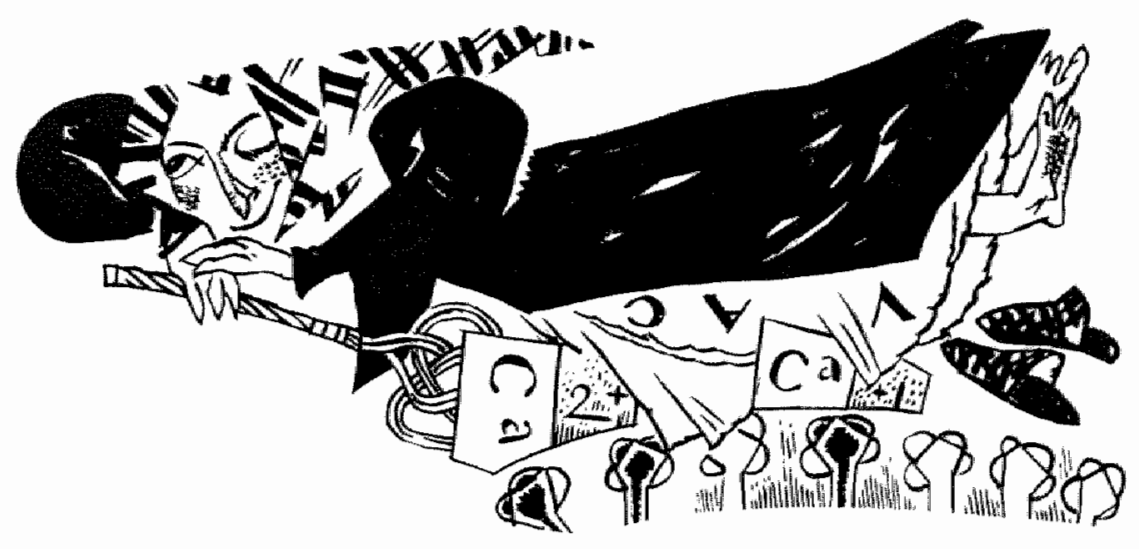



A NEW HOMEOSTATIC MECHANISM TO CONTROL THROMBIN FORMATION AT THE VESSEL WALL LEVEL.

Reutelingsperger, C.P.M., Hornstra, G., Hemker, H.C.

\section{SUMMARY}

vessel wall procoagulant activity was studied by exposing under non-flow conditions rat aortic tissue to citrated autologous plasma, which was recalcified. By fixing the tissue in a specially designed tissue template a standardized area of a pre-determined part of the tissue could be investigated.

The vascular procoagulant activity is enhanced by platelets. Platelet adhesion to and platelet thrombi formation on the subendothelium parallels vessel wall induced thrombin formation, suggesting that these platelet responses and the coagulation process are interrelated.

The procoagulant activity of a standardized area of several vascular structures was measured. Among the vascular structures investigated, the subendothelium exhibits the lowest procoagulant activity. This activity could be abolished by phospholipase C from Bacillus cereus and is therefore likely due to tissue factor activity. The balloon catheter treated luminal side and the abluminal side of the aorta posses higher procoagulart activity.

VAC, a single chain vasculat protein, which inhibits the phospholipid dependent procoagulant reactions through a calcium dependent high affinity binding to the phospholipids, completely inhibits the procoagulant activity of the subendothelium, under the standardized conditions. The activity of the more sever $y$ damaged arta, however cannot be fully blocked by VAC, under those conditions. Since VAC is present in endothelial cells we conclude that VAC provides a novel mechanism to control thrombin formation at the superficially damaged vessel wall. Moreover, VAC may be a useful anticoagulant without the risk of bleeding. 


\section{INTRODOCTION}

The endothelium of a vessel wall provides in 1 ts quiescent state a nonthrombogenic surface,"to which platelets do not adbere (1), and on which anticoagulant activities dominate $(2,3)$.

In experimental studies of the response of blood to vessel injury under flow conditions, it is observed that desquamation of the endothelium leads to a coagulation-independent adherence of platelets to subendothelial components, such as collagen (4) and Won Willebrand factor (5). The adhered platelets spread to cover the exposed subendothelial surface and to form a continuous carpet, on which via coagulation-independent processes, transient thrombi can be formed (6). The spread platelets release some of their granular contents, which penetrate the vessel wali (7). whis sequence of apparently coagulation-independent events is believed to contribute to the process of smooth muscle cell proliferation and the development of atherosclerotic lesions ( 8 ). Following the removal of endothelium in vivo, a neointima of smooth muscle cells is formed (9). Injury to this neointima leads to a platelet accumulation, in which the coagulation cascade seems to be involved $(10,11)$. Tissue thromboplastin activity, reported to be present in the vessel wall (12-14), could be responsible for the generation of thrombin, which then could induce thrombus formation onto the injured neointima.

experiments carried out under conditions in which blood flow is impaired or absent, showed that the injured vessel wall which has not yet developed a neointima, also can induce the generation of thrombin (15).

In this paper we present further evidence that injured vessel wall induces the formation of thrombin, which in turn can activate platelets. These vessel wall induced processes can be regulated by the novel anticoagulant protein VAC, which has been aiscovered and characterized in our laboratory 116 , chapter 2 and 3 of this thesis). By using a specially designed tissue template, we were able to discriminate between the procoagulant activities 
of the different structures of the vessel wall. Structures very close to the vascular lumen possess low procoagulant activity which can be inhibited completely by VAC. Structures more remote from the vascular lumen appear to possess a higher procoagulant activity, which cannot be fully inhibited by vac within the concentration range tested. Based on these results, we suggest that VAC is involved in the homeastatic regulation of coagulation at the vessel wall lining. Upon superficial vascular injury vaC efficiently inhibits the procoagulant activity of the vessel wall and thereby prevents thrombin-mediated platelet activiation and thrombus formation. When deeper injuries occur, and especially at vessel transsection, the stronger procoagulant potential of the deeper vascular layers overrules VAC-activity, as a result of which thrombin can be formed to promote platelet plug formation, fibrin generation and ultimately haemostasis. Thus, VAC may also be a usefull anticoagulant without increasing bleeding tendency. part of this work has been presented in abstract-form before (17).

MATERIALS AND METHODS

Materials - Indomethacin, hirudin grade IV, and phospholipase C (EC 3.1.4.3) from Bacillus cerels were products of sigma (st. Louis, USA). Bovine wascular antilcoagulant was purified from bovine aortic intima following the procedure described in chapter 3 of this thesis. The purified VAC had a speclfic activity of $1500 \mathrm{units} / \mathrm{mg}$, as assessed in the MPr-test (16).

For the purpose of studying vessel wall-induced platelet aggregation and clot formation, a template-like device was designed, In which a piece of vascular tissue can be fixed. This tisue template made of arsenite, enables the exposure of a choosen part of the vascular tissue to a medium. The dimensions of the device (fig. 1) allow it to be put into a glass cuvette, which, in turn, fits into a payton Dual Channel aggregometer module. Hence, when platelet rich plasma forms the medium exposed to the tissue, platelet aggregation and clot formation can be monitored optically. 


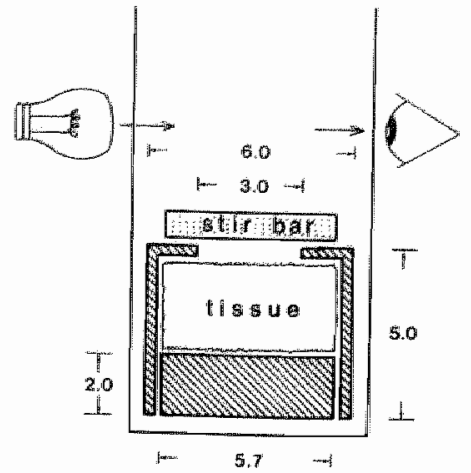

Eig. 1. Schematic presentation of the template, designed to study vessel wall procoagulant activity. The template is constructed af arsenite and its dimensions (expressed in mm) allows it to be placed into a glass cuvette, which fits into a payton Dual Aggregometer. Hence turbidimetric measurements in the medium contacting the tissue is possible.

Preparation of platelet rich plasma - After puncturing the abdominal arta of ether-anaesthetized adult male wistar rats blood was collected and anticoagulated with trisodium citrate (final concentration, f.c., $0.38 \%$ (w/v)). Platelet rich plasma (PRP) was prepared through centrifugation of the anticoagulated blood for $10 \mathrm{~min}$. at $800 \mathrm{x} \mathrm{g}$. The residue was recentrifuged for $10 \mathrm{~min}$. at $2000 \mathrm{x}$ g to obtain platelet poor plasma (PPP). Subsequently, the PPP was centrifuged for $20 \mathrm{~min}$. at $10,000 \mathrm{x} \mathrm{g}$ to give platelet free plasma (PFP).

Isolation of the aorta - Following blood collection, the thoracic and abdominal aorta was dissected, and rinsed with ice-cold Krebs-Henseledt buffer $(\mathrm{K}-\mathrm{H}, 120 \mathrm{mM} \mathrm{NaCl}, 4.7 \mathrm{mM} \mathrm{KCl}, 1.2 \mathrm{mM}$ $\mathrm{MgSO}_{4}, 1.2 \mathrm{mM} \mathrm{KH}_{2} \mathrm{PO}_{4}, 2.5 \mathrm{mM} \mathrm{CaCl} 2,11.6 \mathrm{mM}$ glucose, $25 \mathrm{mM}$ $\left.\mathrm{NaHCO}_{3}, \mathrm{pH} 7.4\right)$. The arta was prepared free of adhering tissue and opened longitudinally. Before further use the isolated aorta was kept 1 hour in $\mathrm{K}-\mathrm{H}$ buffer, containing $10 \mathrm{hg} / \mathrm{ml}$ indomethacin, in order to block prostacyciin formation (18).

Vessel wal1 induced platelet aggregation and clot formation - A plece of arta (5.0 mm in diameter) was punched out mounted in the tissue template and placed into a siliconized aggregation cuvette. Prior to incubation with PRP, PPP, or PFP, the vascular tissue was washed twice with $0.5 \mathrm{ml}$ buffered saline (BS, $4 \mathrm{mM}$ 
$\mathrm{RCL}, 20 \mathrm{mM} \mathrm{NaHCO}, 14 \mathrm{mM}$ glucose, $4 \mathrm{mg} / \mathrm{ml}$ bovine serum albumine and $110 \mathrm{mM} \mathrm{NaCl}, \mathrm{pH} 7.41$. After the second wash, $450 \mu 1$ BS buffer, containing varying amounts of $\mathrm{CaCl}_{2}$, was added to the aggregation cuvette, which was then placed into the Payton Dual Channel Agregometer and stirred at 450 rpm at $37^{\circ} \mathrm{C}$. After $3 \mathrm{~min}$. $l=$ time point zerol, 50, 1 of PRP, PPP, or PFP, was added and platelet aggregation and clot formation, as reflected by change in optical density, were monitored continuously with a flat bed recorder (BD 41 , salm and Kipp). The clotting time $t_{c}$, which is the time (seconds) between addition of the plasma and the occurrence of clot formation, was used to calculate the clotting index, $s$, in the following way:

$$
s=t_{c}^{-1} \times 1000 \text {, }
$$

Coagulation is directly proportional to this clotting index.

Electron microscopy - For electron microscopy, the tissue, mounted in the template, was washed twice with $0.5 \mathrm{ml}$ of $\mathrm{BS}$ buffer, and subsequentiy fixed by the addition of glutaraialdehyde ( $\mathrm{f} . \mathrm{C}$. is $2.5 \%$ in $0.1 \mathrm{M}$ phosphate buffer, pH 7.3).

For transmission electron microscopy, the tissue was further processed, according to the epoxy embedaing method described by Luft (20). In brief, the glutardialdehyde-fixed tissue was washed with phosphate buffer $(0.1 \mathrm{M}, \mathrm{pH} 7.3)$ and fast-fixed with osmium tetroxide ( 18 in phosphate buffer). Subsequently, the tissue was dehyarated in a graded series of ethanol concentrations and finaliy embedded in Epon 812. U1tra-thin sections, obtained with a diamond knife, using a Relchert ultracut Microtome, were stained with uranyl acetate and lead citrate. Micrographs were taken with a Philips CM 12 microscope. For scanning electron inicroscopy, the tissue was postixed in osmium tetraoxide, dehydrated in graded ethanol, critical point dried from $\mathrm{CO}_{2}$, mounted on scanning electron microscope atub, and gold-coated before they were viewed on a Philipis cM 12 microscope with a S.E. detector. 


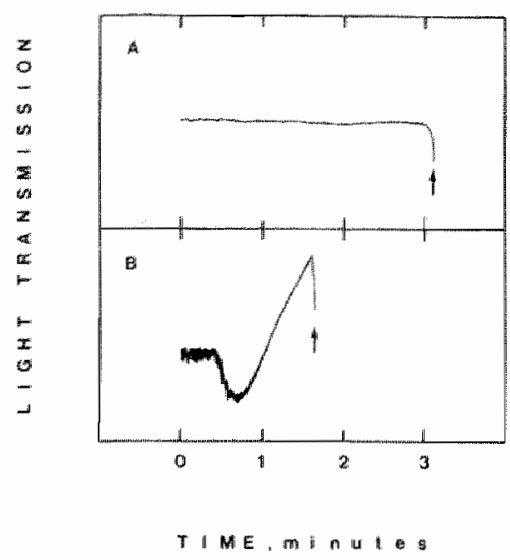

Fig. 2. Optical tracing during the contact of the aortic subendothelium with platelet free plasma (A) and platelet rich plasma (B).

A piece of indomethacin-treated aorta was fixed in the template, exposing the luminal side. Following two rapid washes with BS, the tissue was preincubated with BS, containdng $\mathrm{I}_{\mathrm{mM} \mathrm{CaCl}}$ and $1 \mathrm{mM} \mathrm{MgCl} 2$. After $3 \mathrm{~min}$. $50 \mu 1$ PEP (A) or PRP (B) was added. Light transmission through the medium was recorded with a payton Dual Aggregometer. The arrows indicate the moments of clot formation.

RESULTS

Effects of the aortic tissue on recalcified plasma - Aortas, isolated from rats accoraing to the procedure described in materials and methods, appear to lack an intact endothelium, as judged from electron microscopy (fig. 5B). The lamina elastica interna is covered with amorphous material, which is likely to be composed of the basal membrane and residues of the endothelium. When a piece of this aorta is punched out, mounted in the holder (fig. 1) and exposed to a medium, containing coomassie Briluiant Blue, it is demonstrated that the part of the tissue, ment to be exposed, j.s indeed the only part being in contact with the medium. Typical tracings reflecting changes in optical density during the contact between aortic tissue and recalcified $P F P$ and PRP are shown in fig. $2 \mathrm{~A}$ and $\mathrm{B}$, respectively. Exposure to plasma of the structures, covering the lamina elastica interna 
reveals a procoagulant activity resulting in fibrin formation, which, in the presence of platelets, is preceded by platelet shape change and platelet aggregation. Extensive washing did neither reduce the procoagulant activity of the exposed structures nor did it result in the appearance of procoagulant activities in the washing buffer. Therefore this activity is strongly associated with the tissue and is not released into the medium, under the prewailing experimental conditions.

The procoagulant activity, expressed as the clotting index $s$, depends on the calcium and magnesium concentration of the medium (fig. 3).

The presence of platelets significantly enhance the expression af the procoagulant activity of the aortic tissue (fig. 4). In prp the platelets in the medium clearly change their shape and start to aggregate as a consequence of the exposure to the tissue. These platelets responses are mediated by thrombin, since heparin ( $1 \mathrm{U} / \mathrm{mI}$ ) and hirudin ( $\mathrm{U} / \mathrm{ml})$ completely abolish these platelet effects.

Electron micrascopy of the luminal surface of the artic tissue following the exposure to PRP revealed that when the platelets in suspension start to change shape, the tissue becomes covered with adhered and spread platelets (fig. 5c). When the platelets in suspension start to aggregate, large platelet aggregates have already been formed on the luminal surface of the vascular tissue; these platelet thrombi persist during later aggregation (fig. 5D). The platelets in the aggregates, attached to the tissue, still contain secretion granules. During aggregation no fibrin was observed in or nearby aggregates attached to the tissue. When clot formation has occurred in the plasma, large platelet aggregates are still attached to the vascular surface (5E). This surface and these platelet aggregates are, furthermare, covered with fibrin strands. 


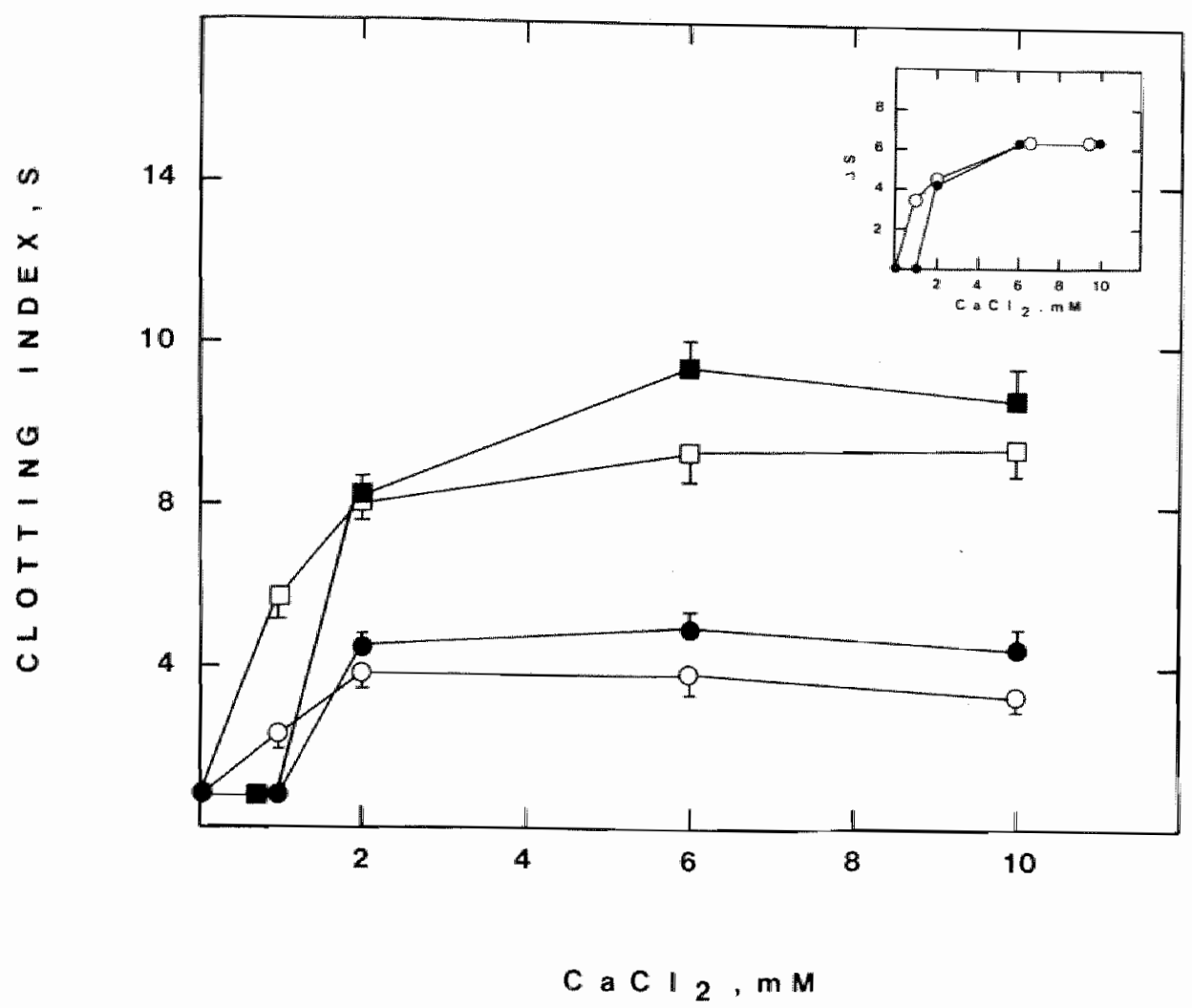

Fig. 3. The effects of calclum and magnesium on the vessel wall procoagulant activity as measured in platelet free plasma.

Indomethacin-treated aorta, Eixed in the template, was exposed with its luminal side to $50 \mu 1$ with $450 \mu I$ BS, contealning varying amounts of $\mathrm{CaCl}_{2}$ with $1 \mathrm{mM} \mathrm{MgCl} 2$ (open symbols) or without $\mathrm{MgCl}_{2}$ (clased symbols). The resulting coagulation times are expressed as clotting indices

(घ, $\square$ ). In control series, coagulation tilmes were recorded under identical conditions, the only difference being the absence of tissue in the template $, 0,0$. The data are the mean $+\operatorname{SEM}(n=4)$.

The insert shows the difference between the clotting indices abtained in the presence of tissue and the ones obtained in the absence of tissue. 


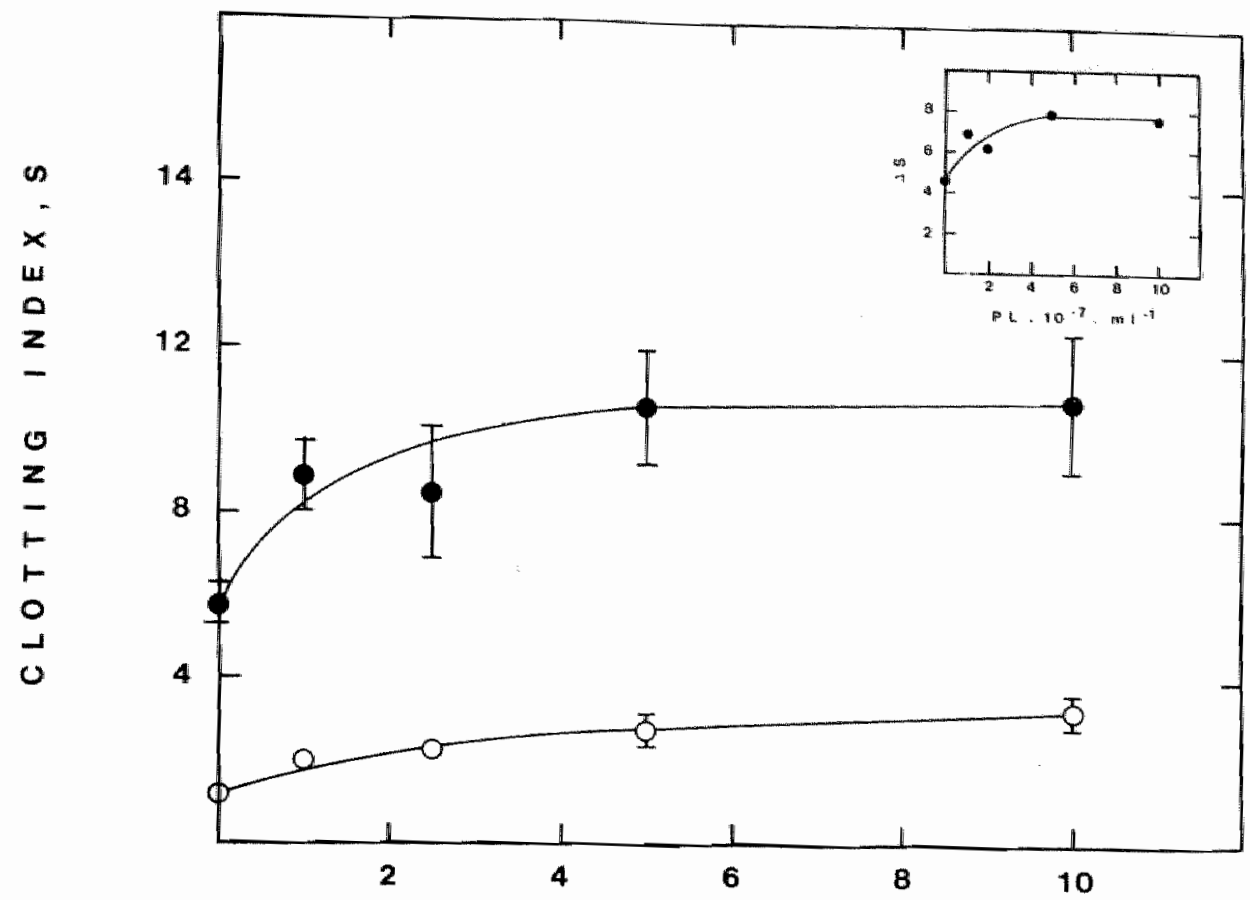

PLATELETS $\cdot 10^{-7} \cdot \mathrm{m} \mathrm{I}^{-1}$

Fig. 4. Effect of the platelet count on the vessel wal1 procoagulant activity.

Indomethacin treated aorta, fixed in the template, was exposed with its luminal side to 50 w PRP with varyling platelet counts, and $450 \mu 1$ BS, contalning $1 \mathrm{mM} \mathrm{CaCl} 2$ and $1 \mathrm{mM} \mathrm{MgCl} 2$. The resulting coagulation times are expressed as clotting indices $(-)$.

In control series, coagulation times were cecorded under identical conditions but in the absence of tissue $(0)$. The data are the mean + SEM of 6 separate experiments. The insert shows the difference in clotting indices between the ones obtained in the presence of tissue and the ones obtained in the absence of tissue. 


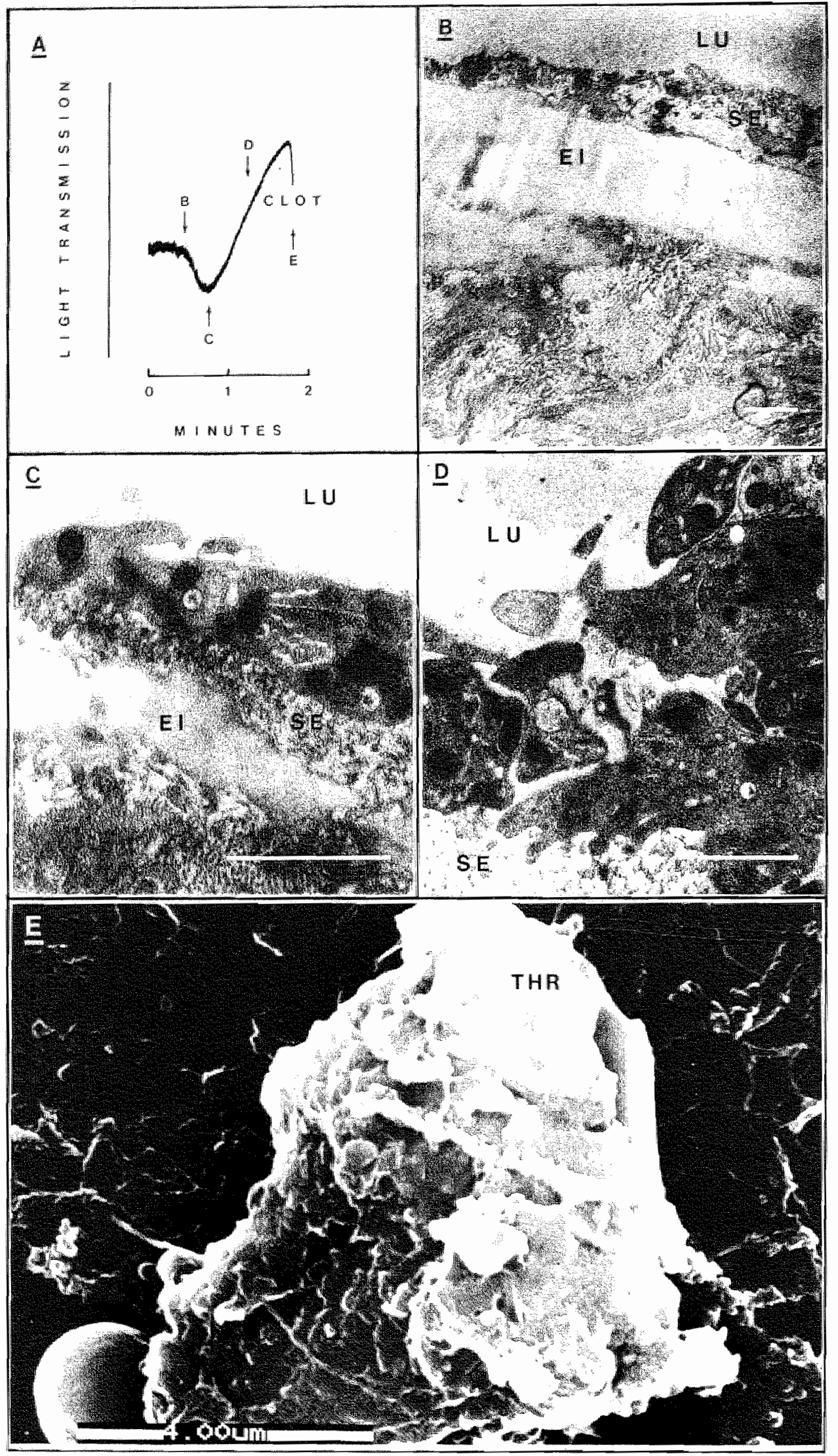


Pig. 5. Electron microscopy of the platelet-vesse1. wall interaction during determination of vessel wall procoagulant activity.

Indomethacin-treated aorta was fixed in the template and exposed with its luminal side to $50 \mu 1$ PRP and 450 H BS, containing $1 \mathrm{mM} \mathrm{CaCl} 2$ and $1 \mathrm{mM} \mathrm{MgCl} 2$. A typical optical tracing is shown in panel. A. The arrows indicate the time points at which the incubation was interrupted, the vascular tissue was rapidly washed, fixed with glutararialdehyde, and prepared for electron microscopic analysis as described in materials and methods. The letters at the arrows correspond with those of the subsequent panels, which show the electron micrographs, obtained at those time points. B-D are transmission micrographs. $\mathrm{E}$ is a scanning micrograph. LU: lumen. SE: subendothelial structures, probably composed of basal lamina and endothellal cesidues. EI: lamina alastica interna. THR: platelet thrombus. The white bars of panels $B-D$ represent the length of $1, \mu \mathrm{m}$.

Effect of the degree of vessel wall damage on the exposed procoagulant activity - In the previous section, it is shown that the aorta, isolated from a rat, already has a superficially damaged luminal side, which exhibits a procoagulant activity. When, prior to its isolation, the aorta is additionally danaged by insertion of a balloon catheter followed by its withdrawal when still inflated, the luminal side of the aorta has a higher procoagulant activity (fig. 6). A severly damaged aorta, which can be mimickea by exposure of the abluminal side of the tissue to the medium, exhibits a very high procaagulant activity (fig. 6). 


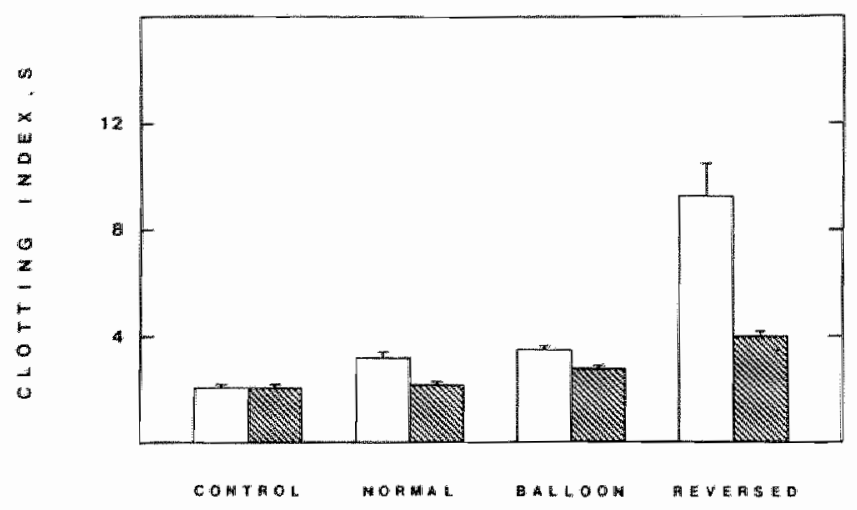

Fig. 6. Effect of the degree of vascular damage on the vessel wall procoagulant activity, and the effect of phosphoIipase $C$ on the procoaguiant activities of the variously damaged vessel walls.

Indomethacin-treated aorta, which was not additionally damaged (normal) or damaged by an indwelling balioon catheter (balloon), was fixed in the template and exposed with lits luminal side to $50 \mu \mathrm{l}$ PFP and $450 \mu 1$ BS, containing $1 \mathrm{mM} \mathrm{CaCl} 2$ and $1 \mathrm{mM} \mathrm{MgCl} 2$. Mormal aorta was also exposed with its abluminal side to this medium (reversed). Coagulation times are expressed as clotting indices copen bars).

prior to exposuce to PFP, the aortic tissues, fixed in the template, were incubated for 30 min. at $37^{\circ} \mathrm{C}$ with 6 I.U. phospholipase C. Subsequently, the tissue was washed and exposed to the pFp containing medium. Resulting clotting indices are given by the hatched bars. control represents the clotting indices, obtained in the absence of $t i s$ sue. The presented data are mean $\pm \operatorname{seM}(n=4)$.

Effects of phospholipase $c$ and VAC on the procoagulant activities of the vessel wall - In order to investigate whether the vascular procoagulant activity is expressed by tissue factor, phospholipase $C$ was employed. Since, antibodies against rat tissue factor were not avaliable, phospholipase $C$ was an acceptable alternative (23). Treatment of the damaged aortas with phospholipase $c$, prior to the exposure to PFP greatly reduces the procoagulant activities of the aortic tissues (fig. 6). The procoagulant activity of the superficially damaged aorta could be completely inhibited by 


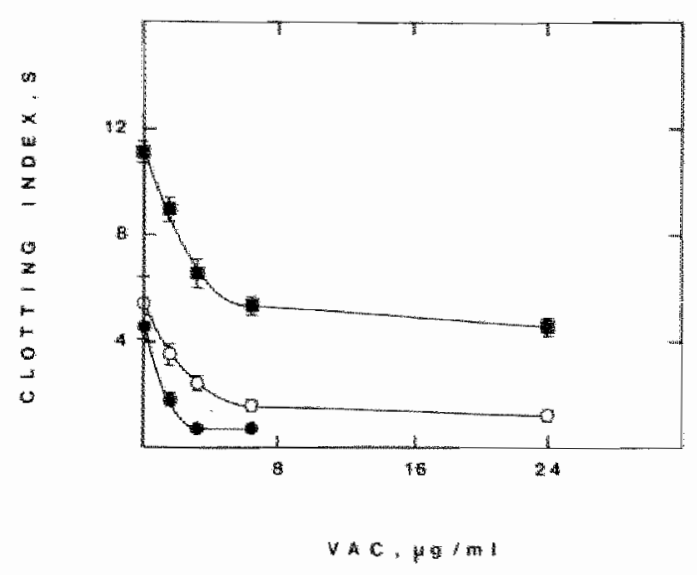

Fig. 7. Effect of VAC on the procoagulant activities of the variousiy damaged vessel wal is.

Indomethacin-treated aorta, not aditionaliy damaged (e) or damaged by an indwelling balloon catheter $(0)$ "was fixed in the template and exposed with its luminal side to $50 \mu 1$ PFP and $450 \mu 1$ BS, containing varying amounts of VAC, I mH CaCl 2 and 1 mM MgCl 2 .

untreated aorta was also exposed with its abluminal side to the medium $(\square)$. Registrated coagulation times are expressed as clotting indices (mean \pm SEM, $n=6$ ).

phospholipase $c$. Furthermore, aortic tissue treated in this way did not induce platelet shape change and aggregation when brought into contact with PRP. The more severly damaged aortas, however, retain a certain procoagulant activity after phospholipase $c$ treatment, under the given conditions. They are also able to induce platelet aggregation prior to clot formation. Comparable results were obtained when the procoagulant activity of the aortic tissue was measured in the presence of VAC (fig. 7). VAC, dose-dependently, inbibits the procoagulant activity of the superficially damaged aorta, which, in turn, fails to activate the platelets in suspension. Control experiments revealed that VAC has no effect on the $A D P$, collagen and thrombin induced platelet activation (data not shown). A complete inhibition by VAC, within the concentration range tested, can apparently not be reached when the aorta is more severly damaged. 
The reduced procodgulant activity of the abluminal side, which was treated wth phospholipase $\mathrm{C}$, could, however, be completed inhibited by VAC within the concentration range of VAC, given in fig. 7 (data not shown). To examine the possible binding of VAC to the damaged aorta and to investigate as to whether the reduced procoagulant activity is a consequence of such a binaing, aortas were incubated with an excess of VAC in the presence of $\mathrm{CaCl}_{2}$. thoroughly washed with BS buffer containing 1 m CaCl2, and subsequently exposed to PFP in a medium containing $1 \mathrm{mM} \mathrm{CaCl} 2$ and $1 \mathrm{mM} \mathrm{MgCl} 2$. The subendothelial structures preincubated with VAC in this way, did not exhibit any procoagulant activity. The presence of $\mathrm{CaCl}_{2}$ during incubation of the tissue with VAC is a prerequisite for this effect, since the omission of $\mathrm{CaCl}_{2}$ prevented the reduction of the vessel wall procoagulant activity, following the incubation with VAC and subsequent washing.

\section{DISCUSSION}

This paper presents a new method to investigate the procoagulant activity of vascular tissue and its effects on platelets and plasma. By means of a tissue template a standardized part of the vascular tissue can be exposed to a medium, in which turbidimetric measurements of clotting and platelet aggregation can then be performed.

In our study we have investigated the procoagulant activity of rat aorta. Inherent to the isolation procedure applied, the aorta lacks an intact endothelial layer. Instead, the lamina elastica interna is covered with subendothelial structures, which appear to exhibit a procoagulant activity. During the experiments performed, this activity remains associated with the subendothelial tissue.

platelets significantly enhance the tissue procoagulant activity, as is in agreement with earlier observations (15). Platelets, once activated, trigger the intrinsic coagulation system (20) and, moreover, expose procoagulant sites on their membrane surface (21), as a result of which thrombin formation is accele- 
rated.

The described experimental set-up to study vessel wall procoagulant activity shows that platelets, when present, first become adherant to the subendothelial structures, after which fibrin free platelet aggregates are formed. The platelets forming these aggregates still contain most of their secretion granules.

The absence of flow in our experiments has the advantage that any thrombin formed during the experiments remains in the imvestigated medium, and is thereafter easily detectable in the presence of platelets. Hence, it is observed that the vessel wall-induced formation of minor amounts of thrombin, which cause platelets to change shape but which do not induce fibrin formation, parallels the platelet adhesion to the subendothelium. The generation of larger amounts of thrombin, which induce platelet aggregation and ultimately fibrin formation, occurs simultaneously with the formation of platelet thrombi on the subendothelial surface. These results suggest that platelet adherence, thrombi formation on the subendothelial surface, and vessel wall induced thrombin formation are interrelated.

Baumgartner and Muggli (6) observed a similar sequence of platelet events, when perfusing subendothelial structures with citrated blood. The presence of the anticoagulant suggests these platelet responses to be coagulation-independent. Ardlie and Han (22), however, reported that platelets have a microenvironment (the "platelet atmosphere"), containing coagulation factors. Within this environment formation of small amounts of thrombin is possible even in the presence of citrate. In agreement to this, Hornstra and Hemker (15) observed vessel wall induced thrombin formation in the presence of platelets at very low calcium concentrations.

EDTA, on the other hand, disturbs the microenvironment of the platelet in such a way that thrombin formation is imposibie (22). In the perfusion chamber of Baumgartner (6) EDTA prevents the spreading of platelets on subendothelial structures, and, moreover, the formation of thrombi. Together with the "platelet atmosphere" theory, these abservations suggest that thrombin can 
be formed in the vicimity of the vessel wall and platelets, emen in the presence of the anticoagulant citrate. This thrombin may be regulred for platelet spreading and thrombus formation. Hence, the role of thrombin during the early events (platelet spreading, platelet thrombi Eormation, etc.) following vessel wall injury, requires reevaluation.

The valar procoagulant activity appears not to be uniformly distributed over the vessel wall. Structures in the vessel wall more remote from the vascular lumen exhibit the highest procoagulant activity, whereas the subendothelial structures apparently posses the lowest activity. This latter activity can be completely inhibited by phospholipase C from bacillus cereus, which inactivates tissue factor activity (23), indicating that tissue factor constitutes the procoagulant activity of the subendothelium. The presence of tissue factor activity in vascular tissue and the synthesis of tissue Eactor by vascular cells, has already been described $(12,13,15,24,25)$. Whether tissue factor is secreted by the vascular cells and forms a part of the extracellular matrix is unknown at the moment.

Structures more remote from the vascular lumen apparently exhibit a procoagulant activity, which could not be completely inhibited by phospholipase $c$, under the given conditions. The reason for this effect remains to be resolved. The procoagulant activity of the superficially damaged aorta can be fully inhibited by VAC. since VAC inhibits the phospholipid dependent procoagulant reactions through its binding to the phospholipids (chapter 3 and 4 of this thesis), we conclude that phospholipids play an essential role in the vascular procoagulant process. Whether VAC binds to the phospholipid moiety of the tissue factor is not known but this is theoretically very well possible.

The amount of VAC, required for complete inhibition of the procoagulant activity of the superficially damaged aorta, is far less than the amount needed for a complete inhibition of the activity of the more severly damaged arta. The procoagulant activity of the artic abluminal side persisted even at the highest concentration of WAC tested (750 nM). 
Together with the presence of VAC in endothelial cells as an anticoagulant compound (chapter 5 of this thesis), we conclude from these results that VAC supplies an anticaagulant mechanism, which can control thrombin formation efficiently at the superficially damaged vessel wall. A more severe damage to the vessel wall, like transsection of the vessel, results in an exposure of a surplus of procoagulant activity which is not efficienty inhibited by VAC. VAC may, therefore, provide an anticoagulant compound, which can be used in the treatment of thrombotic diseases without the risk of bleeding.

\section{ACKNOWLEDGEMENT'}

The authors wish to thank $R$. V. Gool for his technical assistance and P. Bomans for performing the electron microscopy. $\mathbb{P}$. Roszek is acknowledged for typing this manuscript.

\section{ITERATURE}

1. Stemerman, M.B. 1974. In Progress in hemostasis. spaet, T.H. (ed.). Vol 2, pp 1-47. Grune \& Stratton, New York.

2. Nawrath, P.P., Stern, D.M. 1986. J. Exp. Med. 163:740-745.

3. Nawroth, P.P., Handley, D.A., Esmon, C.T., Stern, D.M. 1986. Proc. Nat1. Acad, Sci. USA 83:3460-3464.

4. Baumgartmer, H.R. 1977. Thromb. Haemost. 37:1-16.

5. Stel, H.W., Sakariassen, K.S., Scholte, B.J., Veerman, E.C.I, van der Kwast, Th.H., de Groot, Ph.G., Sixma, J.J., van Mourik, J.A., 1984. B10od 63:1408-1415.

6. Baumgartner, H.R., Muggli, R. 1976. In Platelets in blology and pathology. Gordon, J.L. (ed.) Vol 1, pp 23-60. Elsevier, Amsterdam.

7. Goldberg, I.D., Stemerman, M.B., Handin, R.I. 1980. Science $209: 611-612$.

8. Ross, R., Glomset, J.A., Harker, L.A. 1977. Am. J. Path. $86: 675-684$ 
9. Groves, H.M., Kinlough-Rathbone, R.L., Richardson, M., Moore, S., Mustard, J.P. 1979. Lab. Invest. 40:194-200.

10. Stemerman, M.B. 1973. Am. J. Pathol. 73:7-18.

11. Groves, H.M., Kinlough-Rathbone, R.t., Richarason, M., Jorgensen, L., Moore, S., Mustard, J.F. 1982. Lab. Invest. $46: 605-612$.

12. Astrup, T., Buluk, K. 1963. Circ. Res. 13:253-260.

13. Kirk, J. E. 1962. Proc. Soc. Exp. Biol. Med. 109:890-892.

14. Nemerson, Y.,Pit1ick, F.A. 1972. prog. Hemost. Thromb. $1: 1-37$.

15. Hornstra, G., Hemker, H C. 1979. Haemostasis 8:211-226.

16. Reltelingsperger, C.P.M., Hornstra, G., Henker, H.C. 1985. Eur. J. Biochem. 151:625-629.

17. Reutelligsperger, C.P.M., Hornstra, G., Hemker, H.C. 1985. Thromb. Haemostas. 54: abstract 303.

18. Gryglewski, R.J., Bunting, S., Moncada, S., Flower, R.J., and Vane, J.R. 1976. Prostaglandins 12:685-713.

19. Luft, J. 1961. J. Biophys. Biochem. Cytol. 9:409-412.

20. Walsh, R.N. 1972. Br. J. Haemat. 22:393-405.

21. Bevers, E.M., Comfurius, P., van Rijn, J.L.M. I., Hemker. H.C., Zwal. R.F.A. 1982. Eur. J. Biochem. 122:429-436.

22. Ardile, M.G., Han, P. 1974. Br. J. Haemat. 26:331-356.

23. Otnaess, A.B., Prydz, H., Bjørklid, E.E., Berce, A. 1972. Eur. J. Biochem 27:238-243.

24. Maynard, J.R., Dreyer, B.E., stemerman, M.B., Pitlick, E.A. 1.977. Blood 50:387-396.

25. Hornstra, G. 1981. Phi1. Trans. R. Soc. Lond. B 294:355-371. 
121

CONCLUSIONS AND SUMMARY 


\section{CONCLUSIONS AND SUMMARY}

The discovery of an anticoagulant, that interferes with the interaction between coagulation factors and a phospholipid surface was the result of a study on the vascular procoagulant activity. During this investigation, this activity appeared to be inhibited by a vascular protein, which anticoagulant mechanisn differed from the ones existing in plasma. Preliminary characterization revealed the essential role of phospholipids in this anticoagulant mechanism. The subsequent extensive study on this vascular anticoagulant was not only made possible by the infrastructure of the biochemical department of the university of Limburg, but was also stimulated by it. The present thesis describes the study on this vasculax anticoagulant in extenso. During our attempts to purify this vascular anticoagulant (VAC), we also developed a method to assay VAC-activity and to express this activity in arbitrarily defined units. The resulting modified prothrombin time test (MPT-test) suits these purposes very well, and was employed during the isolation and partial purification of VAC from human umbilical cord arteries. The VAC-activity, present in this tissue, appeared to be associated with a single chain protein with $M_{r}=32,000$. From experiments with the MPT-test it was already obvious that VAC interferes with thrombin formation and not with thrombin action. Studying VAC-activity in a system with purified coagulation factors and phospholipids,

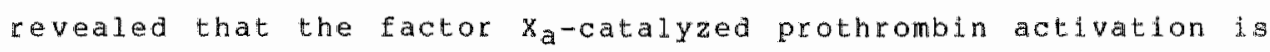
inhibited by VAC, only in the presence of phospholipids. The first indication that phospholipids play an essential role in the anticoagulant action of VAC was, thereby, confirmed.

The 1 inited source of human umbilical cord vessels urged a new one to be found, in order to achieve further characterization of VAC. This new source was found with the demonstration of the presence of VAC-activity in bovine aortic intima. The nearly unlimited supply of this tissue guaranteed the establishment of a purification procedure of bovine VAC (B-VAC). B-VAC activity appeared to be associated with two single chain water-soluble 
proteine $\left(M_{\mathrm{r}}=32,000\right.$ and $\left.M_{\mathrm{r}}=34,000\right)$. The similarities in chemical properties of both proteins prevented their separation sofar. Both protein we shown to bind to large volume phospholipid wesicles. The binding of B-VAC to a phospholipid bilayer, consisting of $20 \%$ DOPS/B0\% DOPC was quantified with the use of an e1lipsometer. This binding requires both calcium and the presence of Dops in the phospholipid surface. Both proteins have the same affinity $\left(K_{a}=6 \times 10^{-9} \mathrm{M}\right)$ for this surface, which contains, moreover , a single class of binding sites for these proteins. Therefore, we assume that both proteins exhibit the same anticoagulant activity.

As a consequence of the high affinity binding of B-VAC to a phospholipid surface, it interferes with the binding of prothrombin and factor $x_{a}$ binding to this surface. This interference is reflected by the effects of $B-V A C$ on the kinetic parameters of the enzymatic prothrombin activation by factor $x_{a}$ in the presence of phospholipids. B-VAC increases the $\mathrm{K}_{\mathrm{m}}$ and decreases the $\nabla_{\max }$ of this reaction. The increase in $K_{m}$ is readily explained by the interference of $B-V A C$ with the prothrombin binding, whereas the decrease in $v_{m a x}$ likely originates from an interference with the binding of factor $x_{a}$. Based on these findings we have postulated the following anticoagulant mechanism for B-vac: Negatively charged phospholipids function as catalyzing components in the procoagulant reactions, involving vitamin k-related coagulation factors. These factors have to bind to the phospholipid surface, for this catalyzing effect. In the presence of B-VAC, the binding of these factors to the phospholipids is impaired as a result of the occupation of the phospholipid surface by B-VAC. Hence, the phosphollpids are shlelded by B-VAC for the binding of k-related coagulation factors. The nature of the binding between B-VAC and the phospholipid surface is not known as yet. Unlike the vitamin k-telated coagulation factors, which require GLA-residues for their phospholipid binding, B-VAC has no GLA-residues.

Having resolved the purification procedure of $B-V A C$ and part of its anticoagulant mechanism, we Eurther investigated human VAC. Using a FPLC-system, which allow a rapid and convenient purifi- 
cation of VAC, we demonstrated that also human placenta contains VAC. This P-VAC appeared identical to the human umbilical cord VAC (U-VAC), as was concluded from a comparative study on the protein chemistry and the anticoagulant action.

P-VAC and B-VAC have similar affinities for a phospholipid surface, containing negatively charged phospholipids. Hence, their anticoagulant mechanism is likely to be identical. This mechanism predicts a P-VAC induced inhibition of the phospholipid dependent intrinsic factor $\mathrm{X}$-activation. This, indeed, appeared to be the case.

An insight into the mechanism of the binding of P-VAC to negatively charged phospholipids was obtained by studying the intrinsic fluorescence of $\mathrm{P}-\mathrm{VAC}$ and the effects of several serine proteases on P-VAC. Both studies indicated that P-VAC does not show a conformational transition prior to phospholipid binding. The tertiairy structure of the p-VAC molecule, that binds to the phospholipid surface in a calcium dependent way, has few or no accessible arginine and lysine residues, but quite some accessible glutamic acid and aspartic acid residues. From these results it can be concluded that P-VAC binds with a stabilized conformation to the phospholipid surface, and calcium ions may bridge between some of VAC's glutamic acid and/ar aspartic acid residues, and the negatively charged mojeties in the phospholipid surface.

The study with the serine proteases further jndicate, that the serine proteases of the coagulation system are not able to cleavo P-VAC.

Sofar VAC has been isolated and purified from homogenates of vascular tissue. In order to gain insight in the localization of VAC in the intact vessel wall, polycional antibodies raised against purified U-VAC, were employed to demonstrate the presence of VAC in cultured vascular cells " Both immunological and chemical studies demonstrated the presence of active vac in cultured endothelial cells. VAC appeared to be localized intracellularly, associated with granular structures. This endogenous VAC Was shown to reduce the procoagulant activity of the intracellular 
structures, which are likely to contain negatively charged phospholipids, which accelerate the procoagulant reactions. By binding to these structures VAC impairs the clot promoting effects of these phospholipids. The presence of a compound with anticoagulant activity within endothelial cells, suggests a strategic function of VAC in the control of thrombin formation at the vessel wall lining. Whether endothelial VAC becomes active as an anticoagulant after endothelial cell damage only depends on whether or not endothelial VAC can be secreted by the intact endothelial cell. This remains to be resolved.

Using a tissue template specially designed to study the effects of damaged vessel wall on platelets and coagulation, it was shown that the subendathelium of the vessel wall has a low procoagulant activity. This activity, nonetheless, induces the Eormation of thrombin, which in turn activates platelets and converts fibrinogen into fibrin. This procoagulant activity can be blocked with relatively small amounts of VAC. Structures of the vessel wall more remote from the vascular lumen exhibit a higher procoagulant activity, which requires relatively large amounts of VAC for complete inhibition. This difference is likely to originate from the difference in amounts of procoagulant phospholipids exposed after damage. The superficially damaged vessel wall may expose smaller amounts of phospholipids, than the more severly damaged blood vessel, for example after transsection. It is expected that the small anounts of VAC, which enable full inhibition of the procoagulant activity of the superficially damaged vessel is insufficient to block the procoagulant activity of the transsected vesse1. In this latter case, coagulation wil proceed and normal. haemostasis occurs.

Based on the elucidated features of VAC, we conclude that we have found with VAC a new physiological mechanism of anticoagulation. Moreover, this anticoagulant mechanism may provide a useful antithrombotic concept without the risk of bleeding, associated with the currently used anticoagulants. 


\section{CONCLUSIES EN SAMENVATTIMG}

De ontdekking van een anticoagulans, dat de interactie tussen een stolfactor en een fosfolipid oppervlak belemmerd, was het resultat van een studie van de vasculaire procoagulant activiteit. Tijdens deze studie bleek deze activiteit gerend te worden door een vasculair eiwit via een mechanisme, dat fundamenteel verschilde van de in het plasma werkzame anticoagulante mechanismen. Uit een eerste onderzoek werd de belangrijke rol van fosfolipiden in dit mechanisme duidelijk. De hierop valgende intensieve studie van dit vasculaire anticoagulans werd niet alleen mogelijk gemakt door de infrastructur van de vakgroep Biochemie van de Rijksuniversiteit Limburg, maar werd ook gestimuleerd door deze vakgroep. Dit proefschrift beschrijet deze studie.

Tijdens de zuivering van het vasculaire anticoagulans (VAC) werd een test ontwikkeld, warmee de VAC-activiteit zowel kwalitatief als kwantitatief bepald kon worden. De gemodificeerde protrombin tijd test (MPT-test) voldeed aan deze voorwarden en werd toegepast tijdens de isolering en gedeeltelijke zuivering van VAC uit humane navelstreng arterien. De in dit weefsell aanezige vac-activiteit bleek gekoppeld te zijn aan een eiwit met eren mollecuulgewicht van 32.000 daltons. Experimenten met VAC en de MPT-test makten al snel duidelijk, dat VAC wel de vorming van trombine remde mar niet de activiteit van trombine. Verder onderzoek in een modelsysteem met gezuiverde stolfactoren en fosfoldpiden leerde dat VAC de omzetting van protrombine in tromble door factor $x_{a}$ remde, alleen wanneer deze omzetting plativond in aanwezigheid van fosfolipiden. Hiermee werd de belangrifke rod van fosfolipiden in het anticoagulant mechanisme van VAC bevestigd. Verdere karakterisering van VAC wera bemoeilijkt door de beperkte hoeveelheid beschikbaar navelstreng weefsel. Da com werd nat een nieuwe bron van vac gezocht. Deze werd gevonden door het aantonen van VAC-activiteit in de intima van runder aorta, dat in vrijwel onbeperkte hoeveelheden beschikbaar was. Een zuiverings procedure van runder vaC (B-VAC) kon ontwikkeld worden. B-VAC bileek te bestaan uit twee eiwlten met molecuul 
gewfichten van 32.000 en 34.000 daltons. Door hun overeenkomsten in chenische eigenschappen was het onmogelijk deze eiwitten van elkar te schelden.

Beide eiwiten bonden met een hoge affiniteit ( $\mathrm{K}_{\mathrm{a}}=6 \times 10^{-9} \mathrm{M}$ ) aan negatief geladen fosfolipiden. De bindingskinetiek liet zien dat belde eiwtten dezelfde bindingsplatsen op het fosfolipid opperviak hadden. Als gevolg van de hoge affiniteit van B-VAC voor negatief geladen fosfoliplden werd de binding van protrombine en factor $x_{a}$ aan fosfolipiden belemmert in aanwezigheid van $B-V A C$. Dit kwam tot uitdrukking in de effecten van B-VAC op de kinetische parameters van de omzetting van protrombine in trombine door factor $x_{a}$ in anwezigheid van fosfolipiden. B-VAC verhoogde de $K_{m}$ en verlaagde de $v_{\text {max }}$ van deze reactie. De verhoging van de $k_{m}$ kon verklaard worden door de invloed van B-VAC op de binding van protrombine aan de fosfolipiden. De verlaging van de vax was het gevolg van de belemmering van de binding van factor $x_{a}$ an het oppervlak. Op grond van deze gegevens postuleerden wij het volgende: Negatief geladen fosfolipiden functioneren als katalysators voor de procoagulant reacties warin vitamin $k$ afhankelijke stolfactoren betrokken zijn. Deze stolfactoren moeten aan het fosfolipid oppervlak binden voor het katalyserende effect. In de aanwezigheid van B-VAC wordt deze binding belemmerd doordat B-VAC het fosfolipid oppervlak bezet en afschermt voor de stolfactoren. De a ard van de binding van $B-V A C$ is nog niet bekend. Echter in tegensteling tot de vitamine k afhankelijke stolfactoren, die GLA-residuen nodig hebben voor deze binding, heeft B-VAC geen GLA-residuen.

Nadat, door de studie in het runder systeem de zuiverings procedure en het anticoagulante mechanisme van VAC, bekend waren, werd het humane VAC verder bestudeerd. Met behulp van een FPLC-systeem was het $V A C$ op een snelle wijze uit humaan placenta weefsel te zuiveren. Het in dit weefsel gevonden VAC (P-VAC) bleek na een vergelijkende studie identiek te zijn met het VAC, dat in humane navelstreng arterien voorkwam.

Het $P$-VAC vertoonde een afiniteit voor een negatief geladen fosfolipid oppervlak, dat vergelijkbaar was met die van B-vac. 
Het anticoagulante mechanisme van P-VAC, dat hierdoor waarschijnLijk identiek aan dat van B-VAC was, voorspelde een remming door P-VAC van de fosfolipid afhankelijke intrinsieke factor $x$-activering. P-VAC bleek inderdad deze activering te remmen.

Een eerste inzicht in de aard van de binding van p-VAC aan negatief geladen fosfolipiden werd verkregen met behulp van intrinsieke fluorescentie en serine proteasen. zowel de intrinsieke fluorescentie als de serine proteasen toonden aan dat P-VAC onder invloed van calcium of EDTA geen conformatie verandering onderging. De tertiaire structur van het p-VAC molecuul, dat aan fosfolipiden bond, had weinig of geen arginine en lysine residuen aan de buitenkant georienteerd mar daarentegen wel een aantal glutamine zuur en/of asparagine zuur residuen. Voor de binding aan fosfolipiden vormden de calcium ionen mogelijk een overbruggings lading tussen de glutamine zuur en/of asparagine zuur residuen en de negatief geladen groepen in het fosfolipid oppervlak. De studie van de effecten van de serine proteasen op VAC toonden tevens aan dat de serine proteasen van het stolsysteem VAC niet konden knippen.

Tot dusver hadden wij VAC gezuiverd uit homogenaten van vatweefsel. Hierdoor bleef de lokalisatie van VAC in de intacte vatwand onbekend. Ter opheldering van deze lokalisatie werden immunologische studies uitgevoerd met antilichamen, die gericht waren tegen VAC. Deze studies lieten zien dat VAC in gekweekte vasculaire enajotheelcelien voorkwam als een intracellulait eiwit, dat verbonden was met gramulaire structuren. Chemische studieg toonden ara dat dit endotheliale VAC een anticoagulante activiteit bezat, dat de procoagulante activitelt van de intracellulaire structuren van de endotheelcel kon remmen. Deze structuren bevatten warschijnlijk fosfolipiden, wataan het VAC via calcium bond en wardoor de stalbevorderende capaciteit van deze fosfolipiden verloren ging. De a anwezigheid van VAC in endotheelcellen suggereerde een strategische functie van VAC in de controle van de trombine vorming, die op het vatweefsel platsvond. Of VAC voor deze functie beschikbar kwam alleen na endotheelcel beschadiging ofwel doordat intacte endotheelcellen vac konden uit- 
scheiden, was nog niet bekend.

Met behulp wan een zogenaamde "template", die ontwikkeld was voor de bestudering van de vasculaire procoagulant activiteit, wera aangetoond dat verschillende structuren in de vatwand een verscbillende hoeveelheid procoagulante activiteit bezaten. Het subendotheel van de vaatwand bezat relatief de lagste activitelt, terwijl de structuren, die verder van het vasculaire lumen verwjderd waren, een relatief hogere activiteit bezaten. Dit verschil was mogelijk het gevolg van het verschil in de hoeveelheld beschikbaar gekomen fosfolipiden. Het subendotheel (de oppervlakkig beschadigde vaatwand) exposeerde waarschijnlijk minder fosfollpiden dan de dieper gelegen structuren van de vaatwand. De procoagulant activiteit van de vatwand structuren werd door VAC geremd. De hoeveelheid VAC, die in stat was de activiteit van het subendotheel volledig te remmen, kon de activiteit van de dieper liggende structuren in de vatwand niet remmen. In dit laatste geval kon stolling gewoon plaats vinden.

Tot besluit kunnen we concluderen dat we met VAC een nieuw fysiologisch anticoagulant mechanisme hebben gevonden. Bovendien levert dit mechanisme wellicht een nieuw antitrombotisch concept, dat geen risico's tot bloedingen met zich meedraagt, zoals dat bekend is van de huidige toegepaste anticoagulantia. 
De schrijver van dit proefschrift weral geboren te schaesberg op 4 oktober 1955. Hij behalde in 1974 het diploma theneum-B an het Eyckhagencollege te schaesberg. Vanaf 1974 studeerde hij scheikunde aan de Rijksuniversiteit vtrecht. Na het kandidatsexamen in 1978 werd met het keuzevak biochemie en de bijvakken klinische chemie en immunologie in 1981 het doctoral diplona behada. vanaf december 1981 is hij werkzam als wetenschappelijk ambtenar bij de vakgroep Biochemie van de Rijksuniversiteit van Limburg, alwar hij onder leiding van dr. G. Hornstra het onderzoek verrichte dat heeft geleid tot dit proefschift.

In februari 1987 is hij benoemd door de Koninklijke Nederlandse Academie der Wetenschappen als Academie-onderzoeker. 